\title{
HYDROLOGY OF AREA 28, EASTERN REGION, INTERIOR COAL PROVINCE, ILLINOIS
}

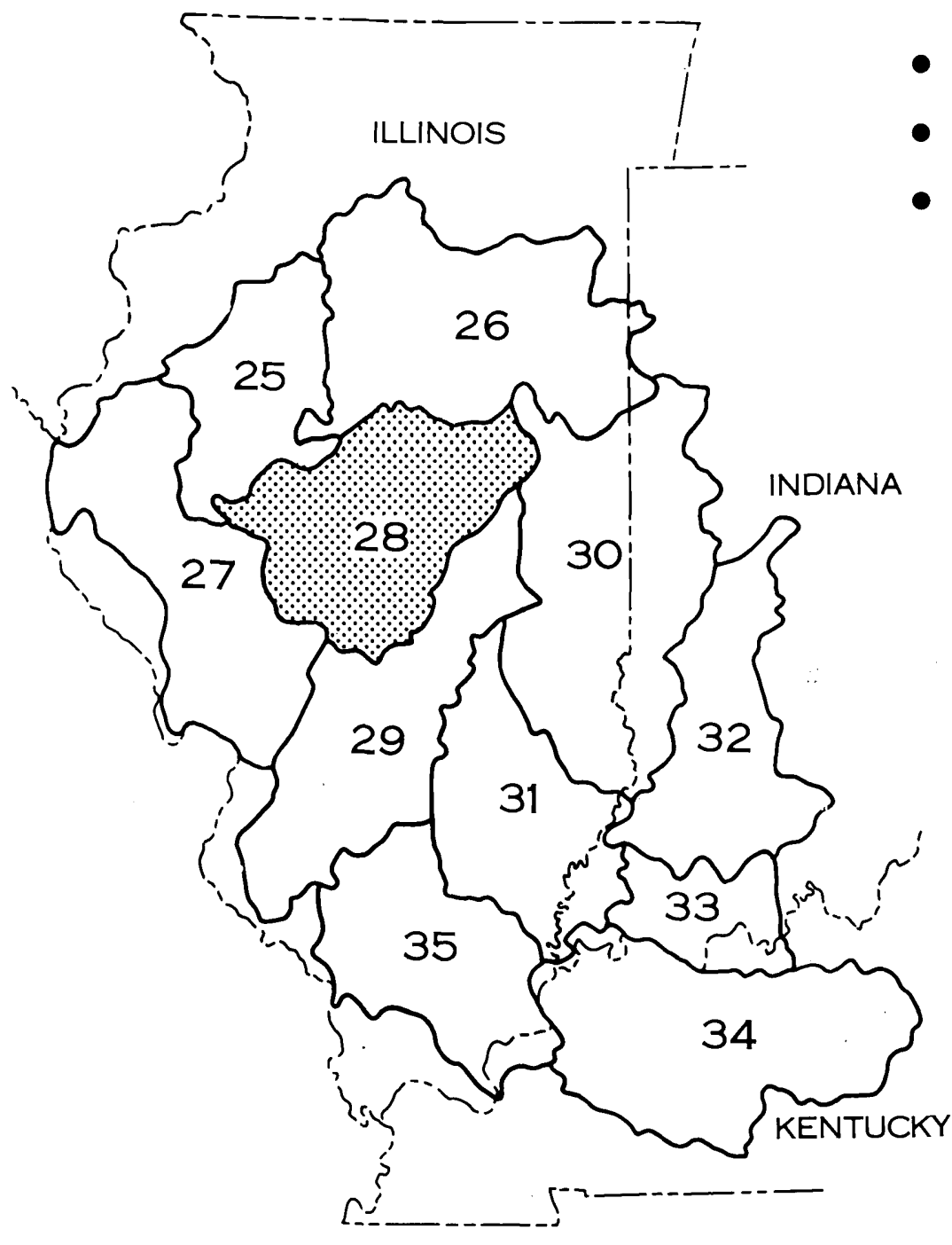

- SANGAMON RIVER

- SALT CREEK

- SOUTH FORK SANGAMON RIVER 


\section{HYDROLOGY OF AREA 28, EASTERN REGION, INTERIOR COAL PROVINCE, ILLINOIS}

BY

E.E. ZUEHLS, K.K. FITZGERALD, AND C.A. PETERS

U.S. GEOLOGICAL SURVEY

WATER-RESOURCES INVESTIGATIONS

OPEN-FILE REPORT 83-544

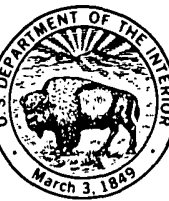

URBANA, ILLINOIS

AUGUST, 1984 


\title{
UNITED STATES DEPARTMENT OF THE INTERIOR
}

\author{
WILLIAM P. CLARK. SECRETARY
}

\section{GEOLOGICAL SURVEY}

\author{
Dallas L. Peck, Director
}

For additional information write to:

District Chief

U.S. Geological Survey

Water Resources Division

Champaign County Bank Plaza

102 East Main St., Fourth Floor

Urbana, Illinois 61801 


\section{CONTENTS}

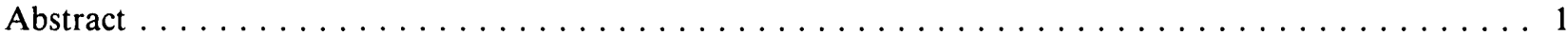

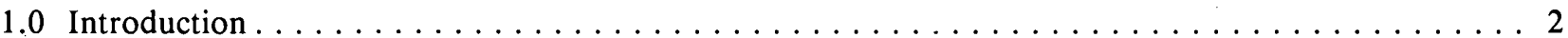

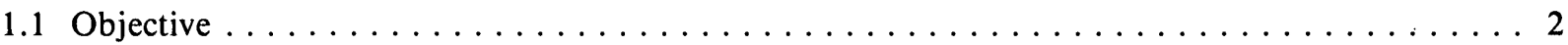

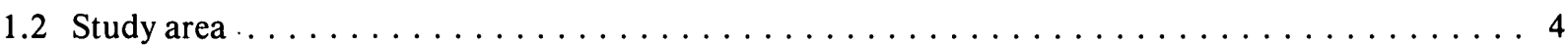

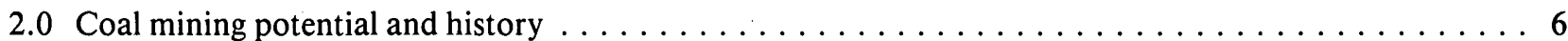

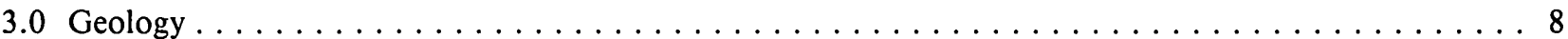

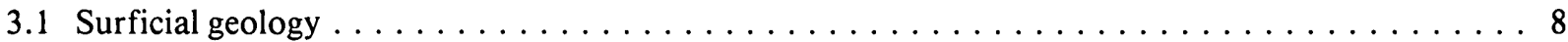

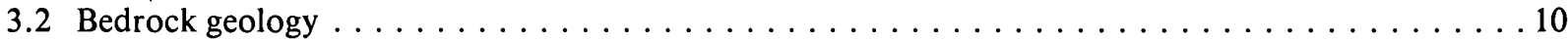

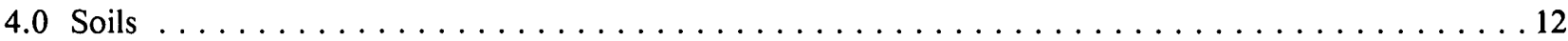

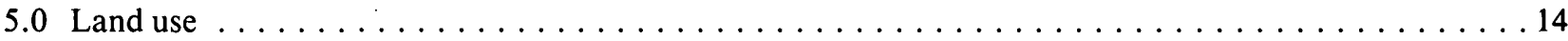

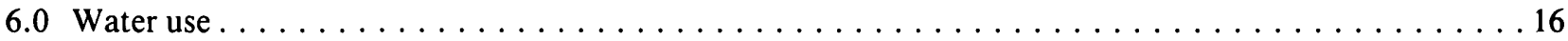

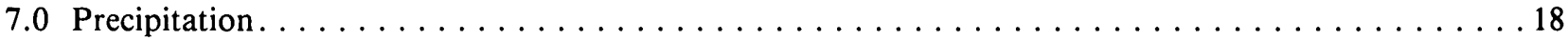

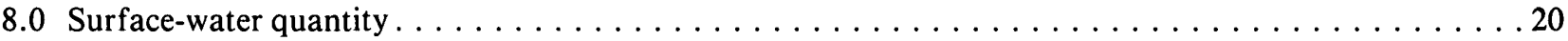

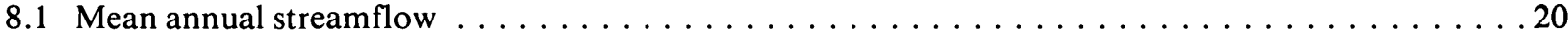

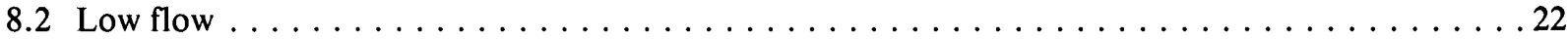

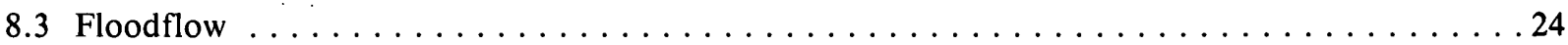

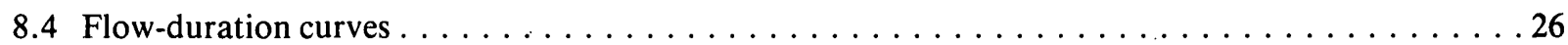

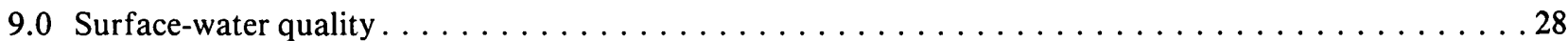

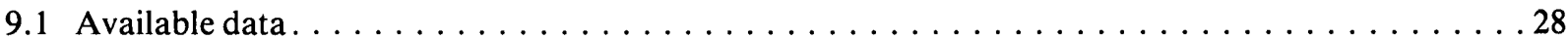

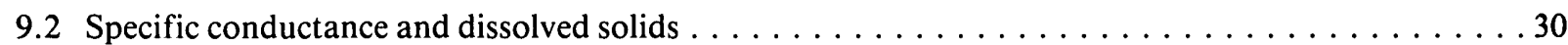

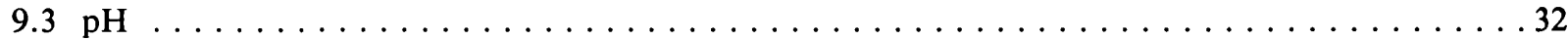

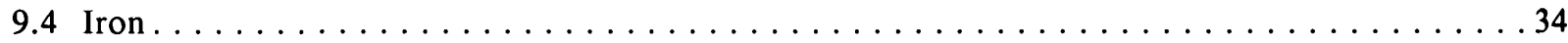

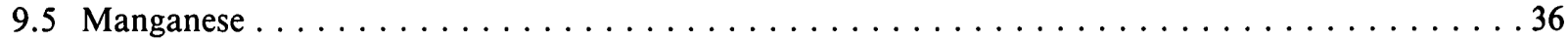

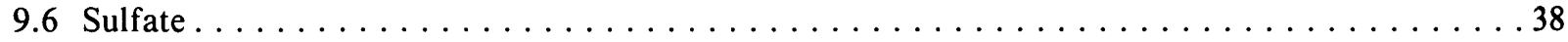

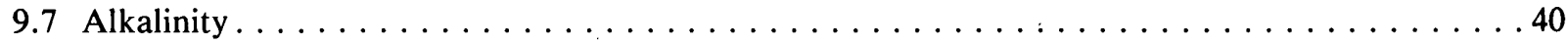

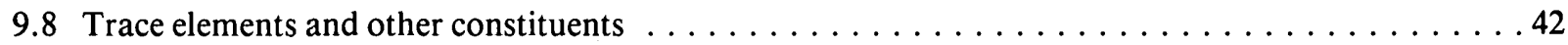

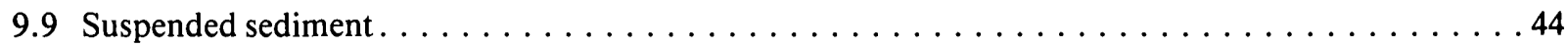

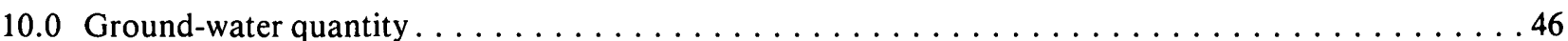

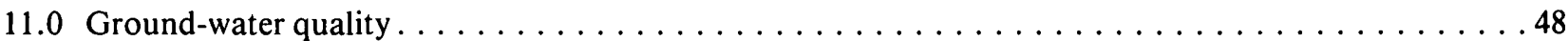

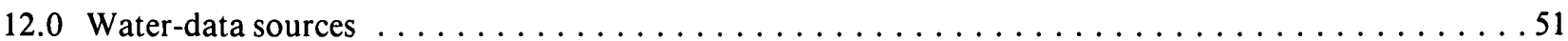

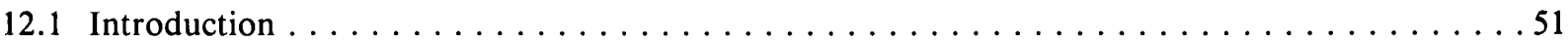




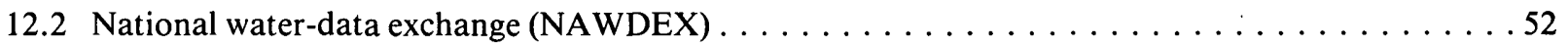

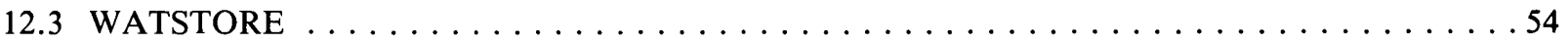

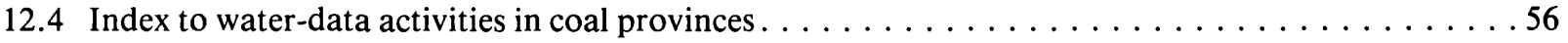

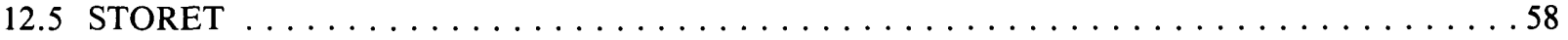

13.0 Surface-water discharge sites and surface-water-quality

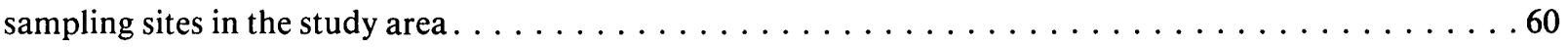

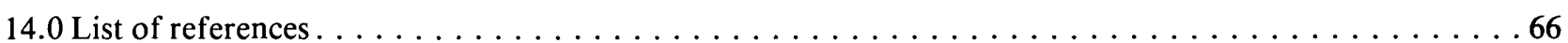




\section{FACTORS FOR CONVERTING INCH-POUND UNITS TO \\ INTERNATIONAL SYSTEM OF UNITS (SI)}

\section{For convenience of readers who may want to use the International System of Units (SI), the data may be converted by using the following factors:}

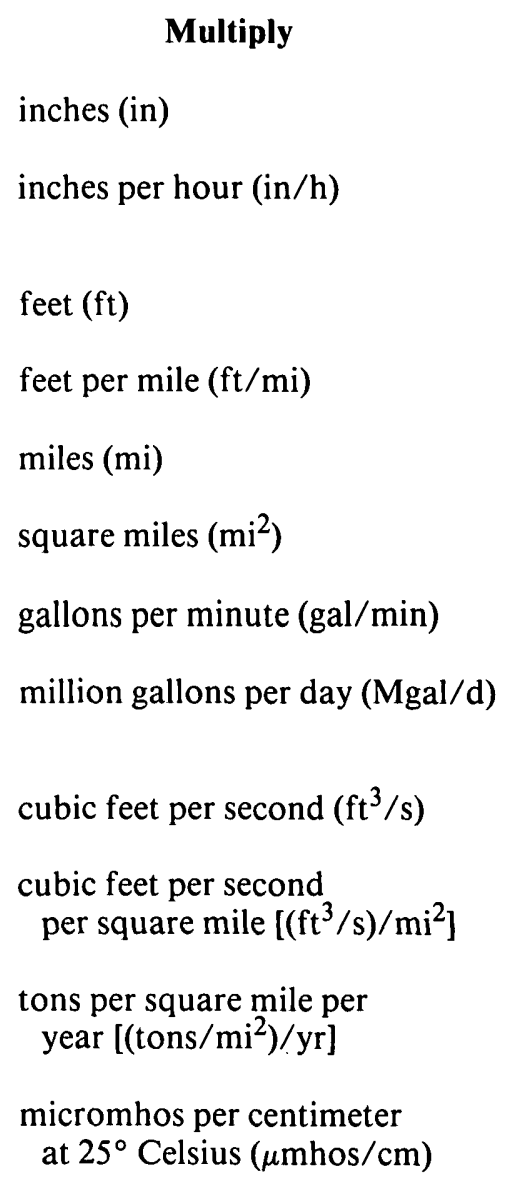

By

25.40

25.4

2.54

0.3048

0.1894

1.609

2.590

0.06309

0.04381 3785

0.02832

0.01093

0.3503

1.000

\section{To obtain}

millimeters (mm)

millimeters per hour $(\mathrm{mm} / \mathrm{h})$ centimeters per hour $(\mathrm{cm} / \mathrm{h})$

meters (m)

meters per kilometer $(\mathrm{m} / \mathrm{km})$

kilometers (km)

square kilometers $\left(\mathrm{km}^{2}\right)$

liters per second $(\mathrm{L} / \mathrm{s})$

cubic meters per second $\left(\mathrm{m}^{3} / \mathrm{s}\right)$ cubic meters per day $\left(\mathrm{m}^{3} / \mathrm{d}\right)$

cubic meters per second $\left(\mathrm{m}^{3} / \mathrm{s}\right) / \mathrm{km}^{2}$

cubic meters per second per square kilometer $\left[\left(\mathrm{m}^{3} / \mathrm{s}\right) \mathrm{km}^{2}\right]$

metric tons per square kilometer per year $\left[\left(\mathrm{t} / \mathrm{km}^{2}\right) / \mathrm{a}\right]$

microsiemens per centimeter at $25^{\circ}$ Celsius $(\mu \mathrm{S} / \mathrm{cm})$

National Geodetic Vertical Datum of 1929 (NGVD of 1929): A geodetic datum derived from a general adjustment of the first-order level nets of both the United States and Canada, formerly called mean sea level. NGVD of 1929 is referred to as sea level in this report. 


\section{HYDROLOGY OF AREA 28, EASTERN REGION, INTERIOR COAL PROVINCE, ILLINOIS}

BY

E.E. ZUEHLS, K.K. FITZGERALD, AND C.A. PETERS

\begin{abstract}
The Eastern Region of the Interior Coal Province is divided into 11 hydrologic reporting areas. The divisions are based upon hydrologic factors, location, and size. Hydrologic units (drainage basins) are combined to form each area. Area 28 is located in central Illinois and includes all of the Sangamon River basin, an area of 5,419 square miles.
\end{abstract}

Abstract

The area reports are designed to be useful to mining companies, their consultants, and regulatory authorities by presenting information concerning existing hydrologic conditions. The hydrology of the area is presented in a format of a series of sections, each with a brief text and accompanying illustration (s) on a single water-resource-related topic.

Major streams in Area 28, in addition to the Sangamon River, are the South Fork Sangamon River and Salt Creek. The southwestern half of the area is in the Springfield Plain physiographic division and the northeastern half is in the Bloomingion Ridged Plain physiographic division. Mean annual rainfall in the area ranges from 35 to 38 inches.

The area is covered with glacial till with a blanket of loess 5 to 10 feet thick on the surface. Pennsylvanian rocks with layers of sandstone, limestone, siltstone, shale, clay, and coal underlie about 90 percent of Area 28. Herrin (No. 6), HarrisburgSpringfield (No. 5), Colchester (No. 2), and Danville (No. 7) coals have been mined in the area. In Illinois, 75 different coal members have been identified in the Pennsylvanian System.
The U.S. Geological Survey operates a network of hydrologic monitoring stations in the study area. Streamflow and water-quality data are collected. These data are available from computer storage through the National Water Data Exchange (NAWDEX) managed by the U.S. Geological Survey.

Mean annual flow, low flow, and floodflow can be estimated at ungaged sites in the study area using equations developed from data collected at streamflow stations. This report presents surface-waterquality data collected at 37 sites. Water samples were analyzed for specific conductance, $\mathrm{pH}$, alkalinity, dissolved sulfate, total recoverable and dissolved iron and manganese, dissolved solids, and other properties. For streams in the study area, specific-conductance values can be multiplied by 0.60 to obtain an estimate of dissolved-solids concentration. The values of $\mathrm{pH}$ ranged from 6.5 to 9.5 , which is a somewhat wider range than that given by Hem (1970) for water "not influenced by pollution."

Ground water is found in unconsolidated materials and in bedrock aquifers throughout the area. Water taken from bedrock aquifers is of poorer quality than water taken from unconsolidated material. Well yields are smaller in bedrock aquifers than in unconsolidated aquifers in most areas. All water samples from collection sites were moderate to very hard. 


\subsection{INTRODUCTION \\ 1.1 Objective}

\section{Area 28 Report to Aid Permitting}

\section{Existing hydrologic conditions and sources of hydrologic information are described.}

A need for hydrologic information and analysis on a scale never before required nationally, was initiated when the "Surface Mining Control and Reclamation Act of 1977" was signed into law as Public Law 95-87 on August 3, 1977. This need is partially met by this report, which broadly characterizes the hydrology of Area 28 in the Eastern Region of the Interior Coal Province in central Illinois (fig. 1.1-1). This report is one of a series that covers the coal provinces nationwide. The report contains a brief text with an accompanying map, chart, graph, or other illustration for each of a number of waterresources related topics. The summation of the topical discussions provides a description of the hydrology of the area.

The hydrologic information presented or availa- ble through sources identified in this report may be used in describing the hydrology of the "general area" of any proposed mine. Furthermore, it is expected that this hydrologic information will be supplemented with the lease applicant's site-specific data as well as data from other sources to provide a more detailed picture of the hydrology in the vicinity of the mine and the anticipated hydrologic consequences of the mining operation.

The information contained herein should be useful to surface-mine owners, mine operators, and consulting engineers in preparing permits, and to regulatory authorities in appraising the adequacy of permit applications. 


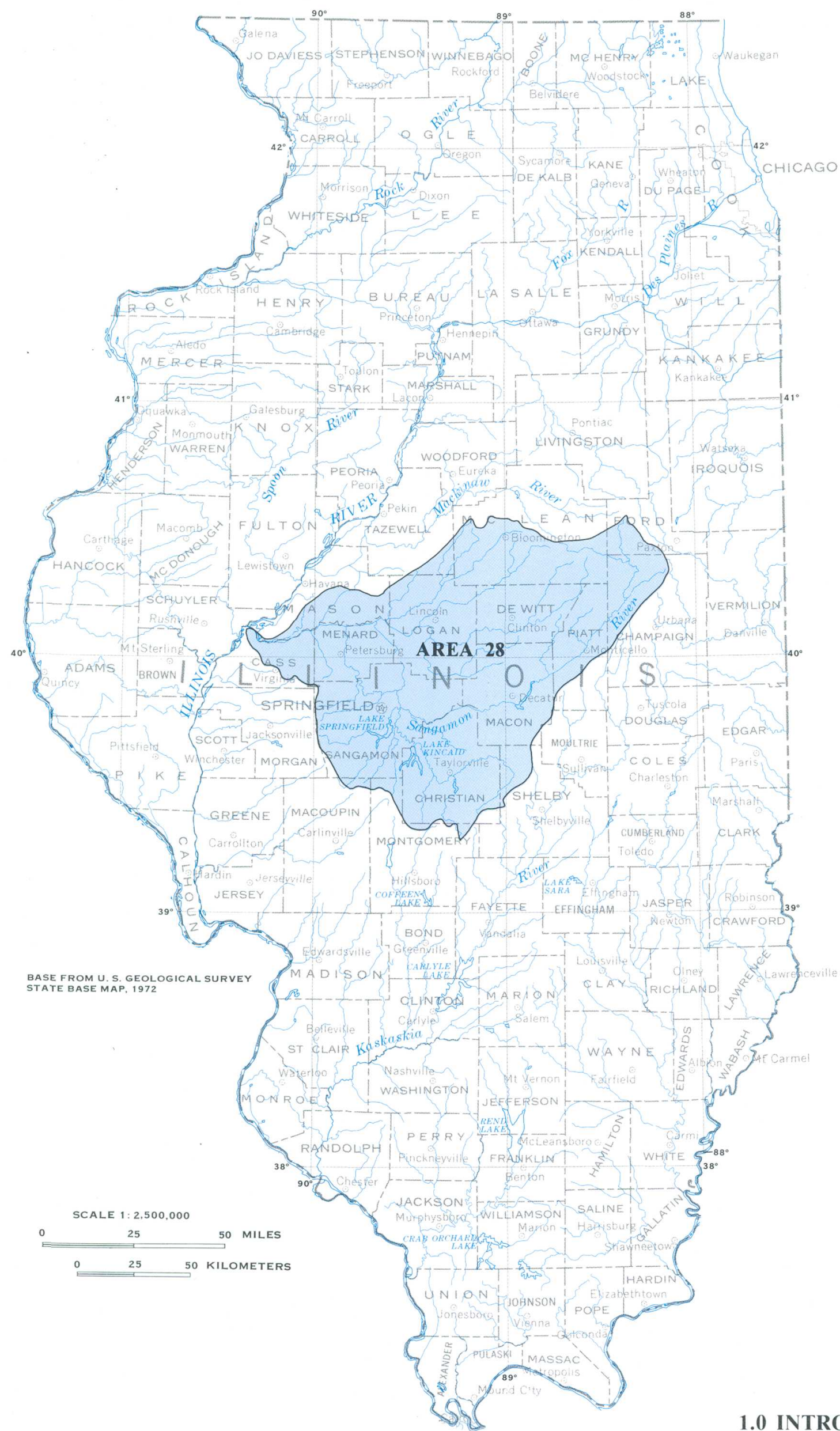




\subsection{INTRODUCTION--Continued \\ 1.2 Study Area}

\section{Area 28 is Located in Central Illinois}

\section{The Sangamon River drains Area 28. Area 28 is within two physiographic divisions: the Bloomington Ridged Plain and the Springfield Plain.}

The Eastern Region of the Interior Coal Province, commonly called the Eastern Interior Coal Field (Smith and Stall, 1975), has been divided into 11 hydrologic study areas. These are shown on the cover of this report. The areas are based on hydrologic factors, location, and size. Hydrologic units are combined to form each study area. Area 28 encompasses the Sangamon River basin and is divided into four hydrologic units (fig. 1.2-1). It covers 5,419 square miles in central Illinois (fig. 1.2-2). It includes Christian, De Witt, Logan, Macon, Menard, and Sangamon Counties and parts of Cass, Champaign, Ford, Mason, McLean, Montgomery, Piatt, Shelby, Macoupin, and Tazewell Counties.

The area includes parts of two physiographic divisions: the Bloomington Ridged Plain and the Springfield Plain (fig. 1.2-3). These are divisions of the Till Plains Section of the Central Lowland Province. The topography of the Bloomington Ridged
Plain is a series of low, broad, morainic ridges alternating with wide areas of relatively flat or gently undulating till plains. The topography of the Springfield Plain is level to gently undulating (Thornburn, 1963).

The population of the area is about 495,000 . The largest cities in the area are Springfield (population $91,753)$, Decatur $(90,397)$, Bloomington $(39,992)$, and Normal $(26,396)$ (Rockford Map Publishers, 1973).

The Sangamon River flows from the northeast to southwest in central Illinois, then north and west to its confluence with the Illinois River about 9 miles north of Beardstown. Salt Creek, which drains 37 percent of the area, is the major tributary to the Sangamon River and drains the north and central parts of the area. 


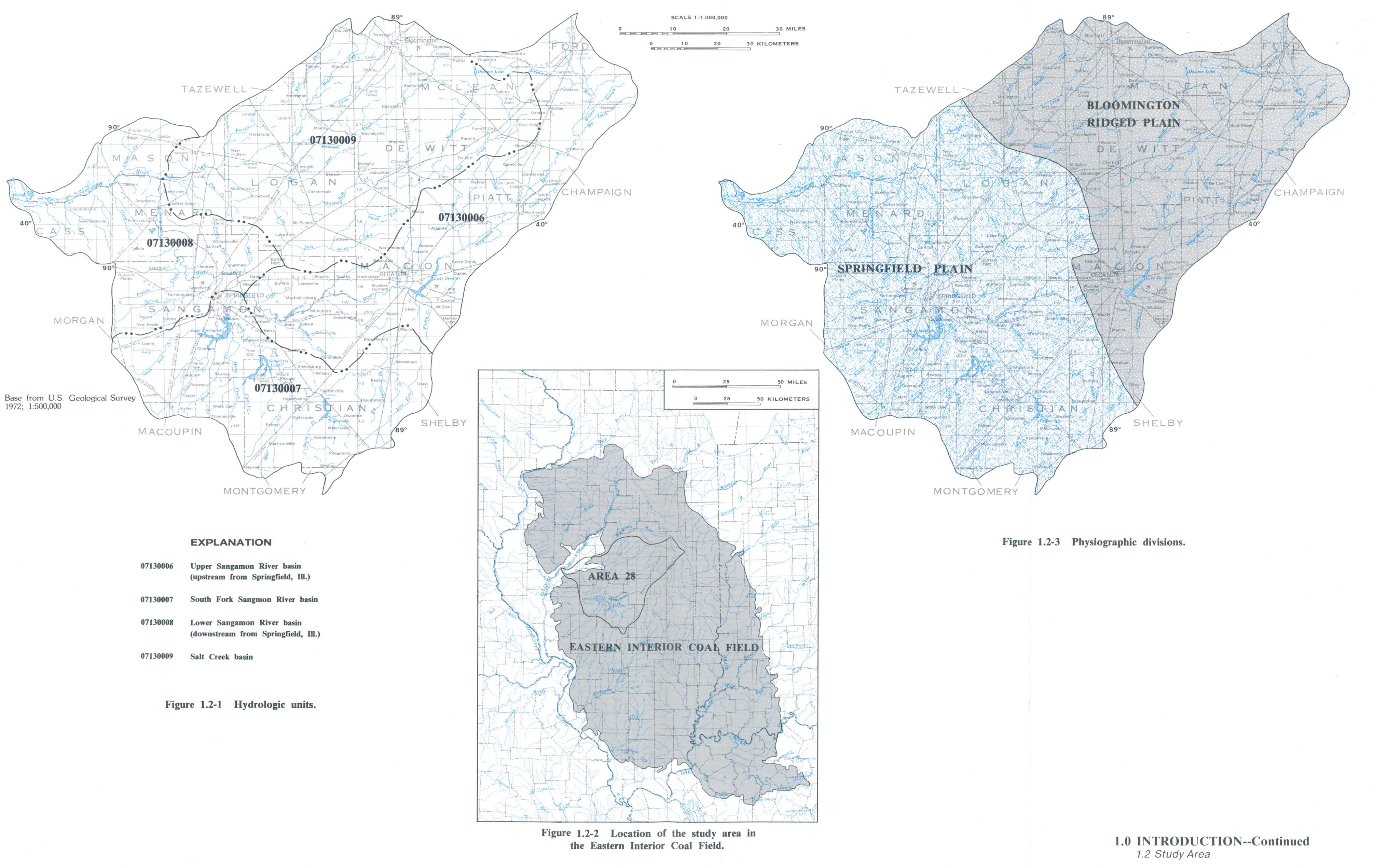




\title{
Illinois has Largest Bituminous Coal Reserves in the United States
}

\author{
Illinois is second only to Montana in total coal reserves. Illinois ranks \\ first in total reserves of bituminous coal. These reserves also have the \\ highest total heat content.
}

\begin{abstract}
Estimated coal reserves in Illinois (as of January 1975 , with revisions in 1980 ) are 161.6 billion tons which is 15.1 percent of the total demonstrated coal reserves in the United States (Nawrot and others, 1980). Illinois ranks first among the States in total bituminous coal reserves. These reserves also have the highest total heat content of any State's reserves in the Nation. Only Montana has larger total coal reserves (Rickert and others, 1979). About 12.1 percent of the Illinois reserves is considered surfaceminable (coal seams more than 18 inches thick and less than 150 feet deep), but currently only about 3.6 percent is economically and legally recoverable (Nawrot and others, 1980).
\end{abstract}

Total identified coal reserves in Area 28, as of January 1976, were about 19.1 billion tons. About 6.6 percent of this reserve is considered surfaceminable (Smith and Stall, 1975, updated in 1977). The surface-minable coal reserves and the two active underground mines in the area are shown in figure 2.0-1. These mines produced nearly 3 million tons of coal in 1981. This is 5.7 percent of the total amount of coal produced in Illinois and 10.1 percent of the coal produced from underground mines in 1981 (Illinois Department of Mines and Minerals, 1982).

Rickert and others (1979) have shown that Illinois coal resources are among those most likely to be used for synthetic fuel production due to the large amount of coal available, plentiful water supplies, lack of serious geologic constraints, and proximity to northeastern markets. In addition, the Nation's move toward energy independence and diminishing domestic supplies of oil and gas could increase the demand for Midwestern coal.

Oil and gas are also produced in Christian, Macon, and Sangamon Counties. These counties produced 1.9 percent (over 400,000 barrels) of the State's total oil production in 1979 (Van Den Berg and Elyn, 1981). The most heavily drilled areas are shown in figure 2.0-1.

The first coal discovery in North America was by Marquette and Joliet in 1673 along the Illinois River. The first commercial underground coal mine in Illinois was opened in 1810 in Jackson County (Andros, 1915). The first commercial surface mine in the United States was opened in 1866 near Danville, Illinois. Early surface mining was accomplished by removing overburden with horsedrawn scrapers and hauling coal out of the mine pit in wagons and wheelbarrows. Within two decades, the steam shovel came into use. The first steam shovels were made mostly of wood and were able to remove 8 to 12 feet of overburden and coal seams up to 3 feet thick. From these beginnings, coal mining technology has progressed to the giant electric-powered shovels of today that can remove up to 220 cubic yards of material in a single bite (Lewis, 1972).

Total coal production in Illinois from 1882 through 1981 was 4.8 billion tons. Area 28 accounted for 3.0 percent of that total. Peak production was reached during World War I. The Depression of the 1930's caused a decline in production which was reversed during World War II. Another decline in production occurred when diesel locomotives and alternate industrial fuel sources came into use. Increased energy consumption and declining oil and gas reserves have resulted in an increase and leveling off of production during the past two decades (Nawrot and others, 1980).

In 1981 , the 27 surface mines in operation in Illinois produced over 22 million tons of coal and the 31 underground mines produced a total of over 29 million tons (Illinois Department of Mines and Minerals, 1982). 


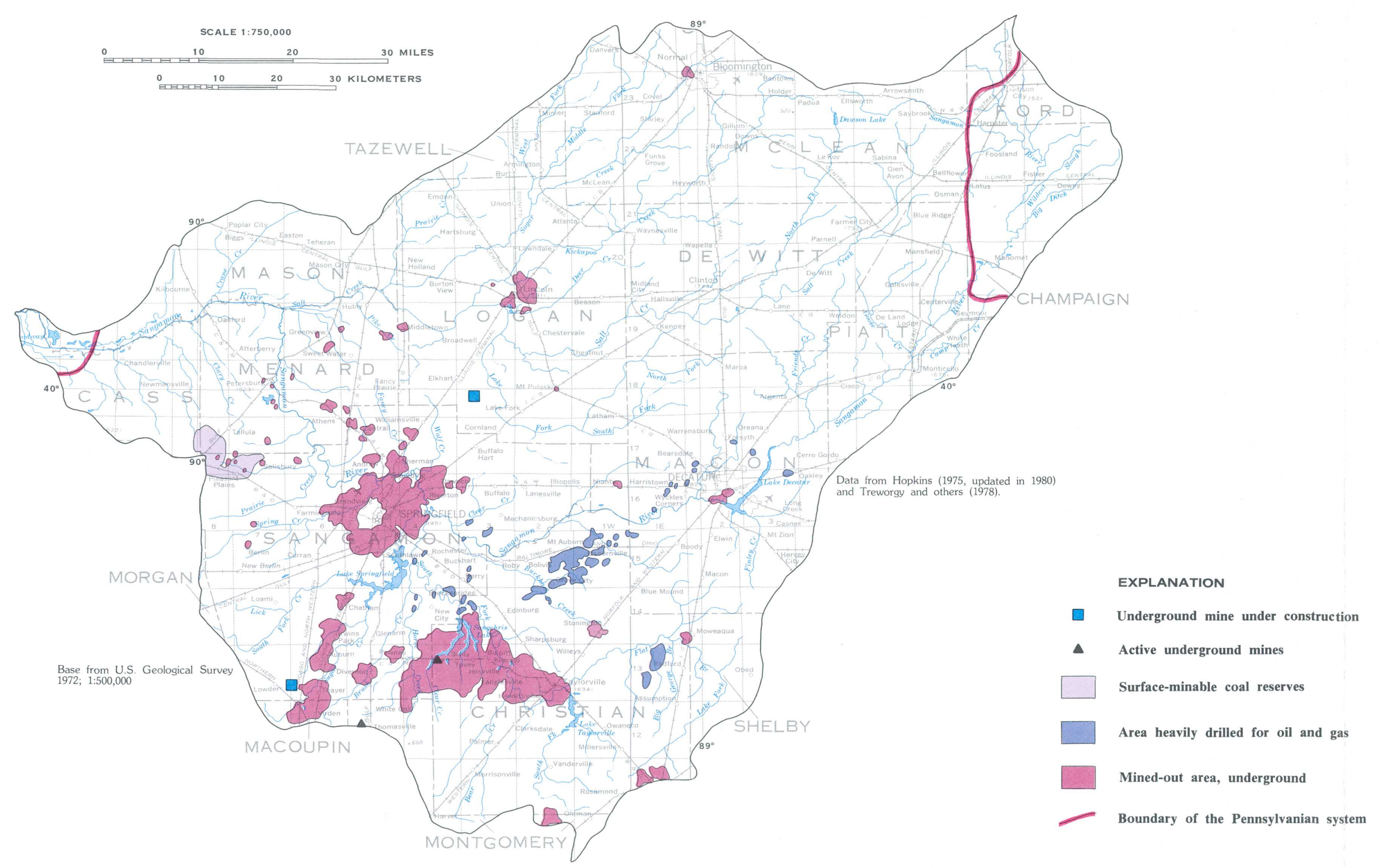




\subsection{GEOLOGY \\ 3.1 Surficial Geology}

\section{Glacial Deposits Cover the Area}

\section{Glacial deposits cover most of Area 28 to a maximum thickness of 400 feet in the Mahomet Bedrock Valley.}

The Quaternary System includes glacial deposits and other sediments deposited during the glacial epoch through the present time. Surficial glacial deposits cover all of Illinois except the northwestern corner and the southern tip. Glacial deposits in Area 28 reach a maximum thickness of 400 feet in the Mahomet Bedrock Valley, the axis of which is shown in figure 3.1-1. The glacial deposits are of Illinoian and Wisconsinan age. The Wisconsinan glacier was the last to cover the area. Loess 5 to 10 feet thick, of Wisconsinan age, was deposited when outwash material was blown from the valleys into the uplands (Lineback, 1979).

Stratigraphic members of the Glasford Forma- tion of Illinoian age cover the western half of Area 28. They are silty to sandy tills with interbedded sand and gravel and are generally calcareous. Members of the Wedron Formation of Wisconsinan age cover the eastern half of the area. They are silty to sandy tills with lenses of silt, sand, and gravel. Other formations found in the area are shown and described in figure 3.1-2.

Peoria Loess of Wisconsinan age is a massive, well-sorted silt and blankets most of Area 28. Peoria Loess is the parent material for many of the soils in the area (Willman and others, 1975). 

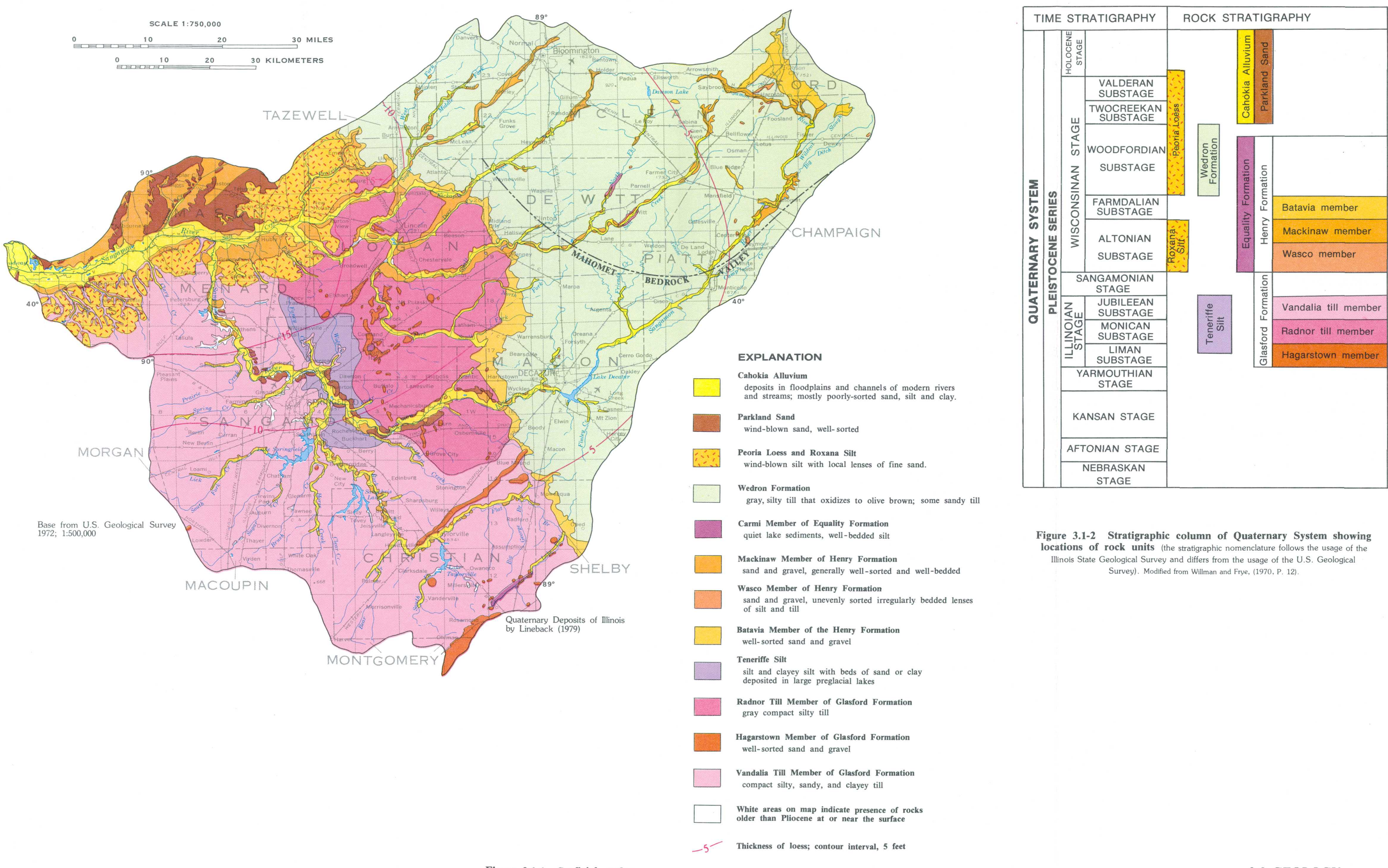

Figure 3.1-2 Stratigraphic column of Quaternary System showing Illinois State Geological Survey and differs from the usage of the U.S. Geological
Int

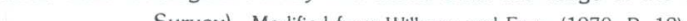




\subsection{GEOLOGY--Continued \\ 3.2 Bedrock Geology}

\section{Four Geologic Units Make Up the Bedrock Surface}

\section{The Pennsylvanian System forms the upper bedrock in about 90 percent of Area 28.}

The Pennsylvanian System is the uppermost bedrock in about 90 percent of Area 28. The underlying rocks of Mississippian, Devonian, and Silurian age make up the bedrock surface in the rest of the area (fig. 3.2-1).

The Pennsylvanian System in the area ranges from 0 to 1,200 feet thick. The rocks dip gently toward the southeast into the Illinois Basin, which is a spoon-shaped structure that is oriented northnorthwest to south-southeast, with the deepest part in southeastern Illinois. The Pennsylvanian System consists of sandstone, siltstone, limestone, shale, clay and coal. The lower section of the Pennsylvanian System in Illinois is 60 percent sandstone, 39 percent siltstone and shale, and less than 1 percent coal and limestone. Twenty-five percent of the middle and upper sections is sandstone, 5 to 10 percent is limestone, and 65 to 70 percent is shale and clay. Coal makes up no more than 2 percent of the Pennsylvanian System, and is more prominent in the middle section (fig. 3.2-2) (Willman and others, 1975).
The depth to the Herrin No. 6 coal, mined at the two active underground mines, ranges from less than 200 feet in the western part of the area to 800 feet in Shelby County (Smith and Stall, 1975). In the past, the Harrisburg-Springfield (No.5), Colchester (No. 2), and Danville (No. 7) coals also have been mined in the area (Nawrot and others, 1980).

Changes in lithology commonly are abrupt, indicating that the depositional environment at times was changing rapidly. The advance of saltwater seas into Illinois resulted in transgressive marine deposition of sandstone, shale, and limestone. As the seas receded, large freshwater swamps developed on broad deltaic plains. When the seas readvanced, marine sediments were deposited on top of the swamp debris. Biochemical and physical changes took place as the partially decayed plant material (peat) was buried, resulting in the formation of 75 identifiable coal members in Illinois. 

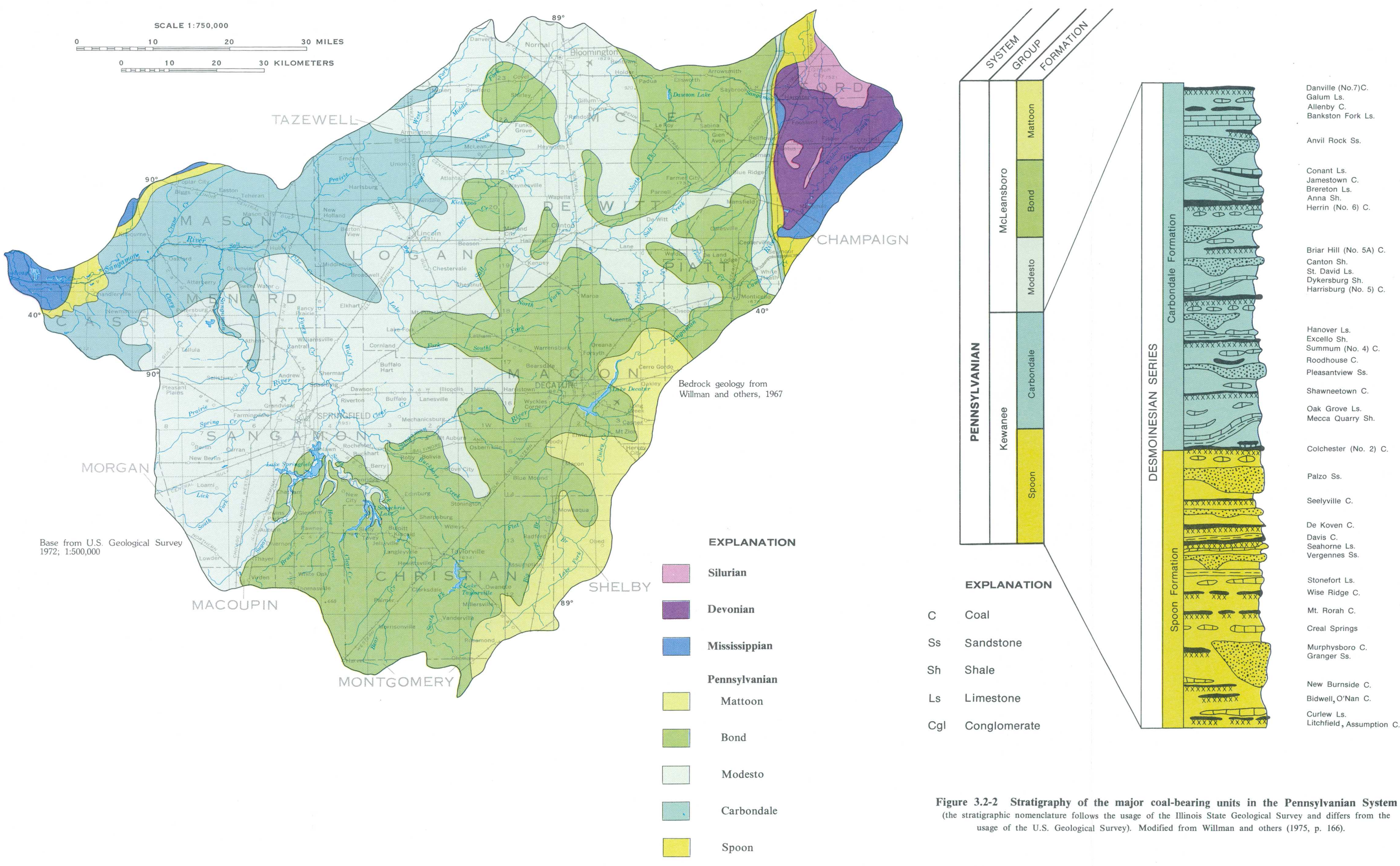


\title{
4.0 SOILS
}

\section{Area Soils are Good for Agricultural Productivity}

\author{
Soils are of moderate to high productivity. Erosion control is a problem on \\ slopes. Area soils have a wide range of permeability and $\mathrm{pH}$ values.
}

The soils in Area 28 are moderately to highly productive under intensive management (application of plant nutrients, maintenance of drainage, control of flooding and erosion, and control of weeds, diseases, and insects). Soils in Area 28 have permeabilities from 0.2 to 6.30 inches per hour and $\mathrm{pH}$ values from 4.5 to 8.4 . The predominant soil associations $\mathrm{A}$ and $\mathrm{B}$ have severe erosion problems on less than 9 percent of their area. Average annual soil loss is 0 to 10 tons per acre (U.S. Department of Agriculture, 1980). Bedrock outcrops are common where soils have been eroded. General descriptions of the soil associations in the area are given in table 4.0-1. These descriptions were compiled from soil surveys for individual counties (U.S. Department of Agriculture, 1974, 1980; Fehrenbacher and others, 1967; and Fehrenbacher and Odell, 1953).

The soil associations present in Area 28 are shown in figure 4.0-1. Most soil associations were developed from loess. Loess is a silty wind deposit that was produced by outwash material blown from the valleys onto the uplands during glacial times. When the loess was deposited, it was calcareous and contained many important plant nutrients. It was a friable, medium-textured silt loam with high moisture-storage capacity and formed very productive soils (Fehrenbacher and others, 1967). Thickness of loess in the area ranges from 5 to 10 feet (Lineback, 1979). Ground-water seepage may occur at the contact of the loess with the underlying drift or bedrock resulting in slope failure. To help prevent slope failure, slopes are benched and gutters are used at the top of the slopes and on the benches (Thornburn, 1963).

Soil association $\mathrm{Z}$ was developed from alluvium, which includes recent sediments deposited by streams on their flood plains. The grain size of these sediments range from sand to clay.

Soil associations $\mathrm{W}$ and $\mathrm{X}$ were developed from outwash materials that were deposited in the major river valleys by meltwater during the Illinoian and Wisconsinan glaciations. The grain sizes of the materials range from gravel to clay.

Soil associations $\mathbf{J}$ and $\mathrm{K}$ were developed from Illinoian age glacial till (Fehrenbacher and others, 1967). These soils were formed on the steeper slopes in the eastern part of the area and have a lower moisture-storage capacity and are more compact than loess.

Information on the engineering properties of soils in Area 28 and detailed soil maps can be found in soil surveys for individual counties. These are published by the U.S. Soil Conservation Service in cooperation with the University of Illinois Agriculture Experiment Station. Soil surveys and other information can be obtained from State and county offices of the Soil Conservation Service. Recent soil surveys are available for Sangamon, Logan, and Menard Counties. A report by Wischmeier and Smith (1978) contains useful information for predicting erosion losses from rainfall. 


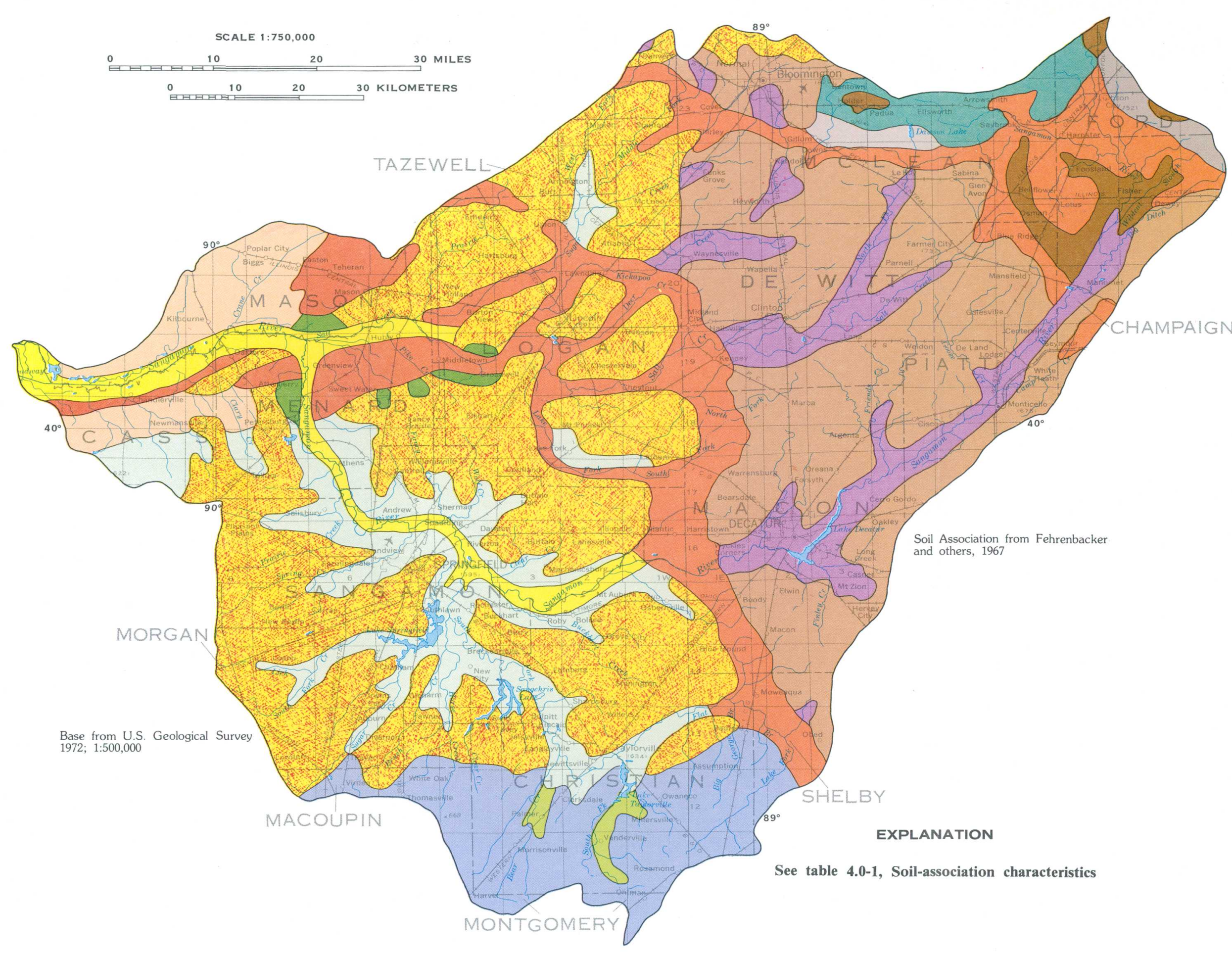

\begin{tabular}{|c|c|c|c|c|c|}
\hline Soll association & $\begin{array}{l}\text { Depth to } \\
\text { bedrock } \\
\text { (feet) }\end{array}$ & $\begin{array}{l}\text { Depth to } \\
\text { high water } \\
\text { table } \\
\text { (feet) }\end{array}$ & $\begin{array}{l}\text { Permeability } \\
\text { (inches } \\
\text { per hour) }\end{array}$ & $\begin{array}{c}\text { Avallable } \\
\text { water } \\
\text { capacity } \\
\text { (inches per } \\
\text { inch of soil) }\end{array}$ & $\begin{array}{l}\text { Soil } \\
\text { reaction } \\
\text { pH }\end{array}$ \\
\hline \multicolumn{6}{|l|}{$\begin{array}{l}\text { Dark-Colored Soils } \\
\text { Developed primarily from loess }\end{array}$} \\
\hline Joy-Tama-Muscatine-Ipara-Sable & NA & $0-6+$ & $0.20-2.0$ & $0.11-0.24$ & $5.1-7.8$ \\
\hline Sidell-Cattin-Flanagan-Drummer & NA & NA & $0.20-2.0$ & $0.16-0.25$ & $5.6-8.4$ \\
\hline Harrison-Herrick-Virden & $5+$ & $0-2$ & $0.20-2.0$ & $0.11-0.24$ & $5.6-8.4$ \\
\hline \multicolumn{6}{|l|}{ Developed primarily from glacial drift } \\
\hline LaRose-Saybrook-Lisbon & NA & NA & NA & NA & NA \\
\hline Elliott-Ashkum-Andres & NA & NA & NA & NA & NA \\
\hline Swygert-Bryce-Clarence-Rowe & NA & NA & NA & NA & NA \\
\hline \multicolumn{6}{|l|}{$\begin{array}{l}\text { Light-Colored-Soils } \\
\text { Developed primarily from loess }\end{array}$} \\
\hline Seaton-Fayette-Stronghurst & $5+$ & $5+$ & $0.60-2.0$ & $0.18-0.23$ & $4.5-7.8$ \\
\hline Birkbeck-Ward-Russell & $5+$ & $5-10$ & $0.63-2.0$ & $0.14-0.25$ & $5.1-8.4$ \\
\hline Clary-Clinton-Keomah & $5+$ & $0-4$ & $0.20-2.0$ & $0.18-0.25$ & $4.5-8.4$ \\
\hline Hosmer-Stoy-Weir & NA & NA & NA & NA & NA \\
\hline \multicolumn{6}{|l|}{ Developed primarily from glacial drift } \\
\hline Strawn-Miami & NA & $5-10$ & $0.63-2.0$ & $0.14-0.20$ & $5.6-8.4$ \\
\hline \multicolumn{6}{|c|}{$\begin{array}{l}\text { Dark- and Light-Colored Soils } \\
\text { Developed primarily from medium and fine textured outwash }\end{array}$} \\
\hline $\begin{array}{l}\text { Littleton-Proctor-Plano- } \\
\text { Camden-Hurst-Ginat }\end{array}$ & ${ }^{5+}$ & 5-10 & $0.60-6.3$ & $0.10-0.25$ & $5.1-8.4$ \\
\hline \multicolumn{6}{|l|}{ Developed primarily from sandy material } \\
\hline Hagener-Ridgeville-Bloomfield-Alvin & $5+$ & $6+$ & $0.60-2.0$ & $0.05-0.20$ & $5.1-7.8$ \\
\hline \multicolumn{6}{|l|}{ Developed primarily from alluvium } \\
\hline $\begin{array}{l}\text { Lawson-Beaucoup-Darwin- } \\
\text { Haymonde-dekiknap }\end{array}$ & $5+$ & $1-3$ & $0.60-2.0$ & $0.2-0.25$ & $6.1-7.8$ \\
\hline
\end{tabular}

Figure 4.0-1 Soil associations.

NA-data not available 


\title{
5.0 LAND USE
}

\section{Agriculture is Dominant Land Use}

\author{
Eighty-one percent of Area 28 is used for agriculture. There are no surface \\ mines in the area and underground mining has affected 0.04 percent of the \\ total land area.
}

\begin{abstract}
Area 28 covers about 5,419 square miles in central Illinois. Agriculture is the dominant land use with 73.5 percent cropland and 7.9 percent pasture. The main crops are corn and soybeans. Beef cattle and hogs also are raised. The remainder of the area is used in the following ways (fig. 5.0-1): 8.5 percent woodland, 6.1 percent urban land, 0.5 percent surface-water impoundments, 0.2 percent small water areas (ponds from 2 to 40 acres in size and streams less than $1 / 8$ mile wide), 0.04 percent land affected by underground coal mining, and 3.2 percent other land (rural land not used as cropland, pastureland, or woodland) (Illinois Conservation Needs Committee,
\end{abstract}

1970; U.S. Department of Agriculture, 1980; Illinois Environmental Protection Agency, 1978).

There are no surface coal mines in Area 28. Although only 0.04 percent of the land surface has been affected by underground coal mining, approximately 4.1 percent of the area has been undermined (13 percent of Christian County and 12 percent of Sangamon County) (Nawrot and others, 1980). There are two active underground mines and two under construction in the area (Hopkins, 1975, updated in 1980). Sand and gravel and stone are also mined in the area. Oil is produced in Christian, Macon, and Sangamon Counties (Samson, 1981). 


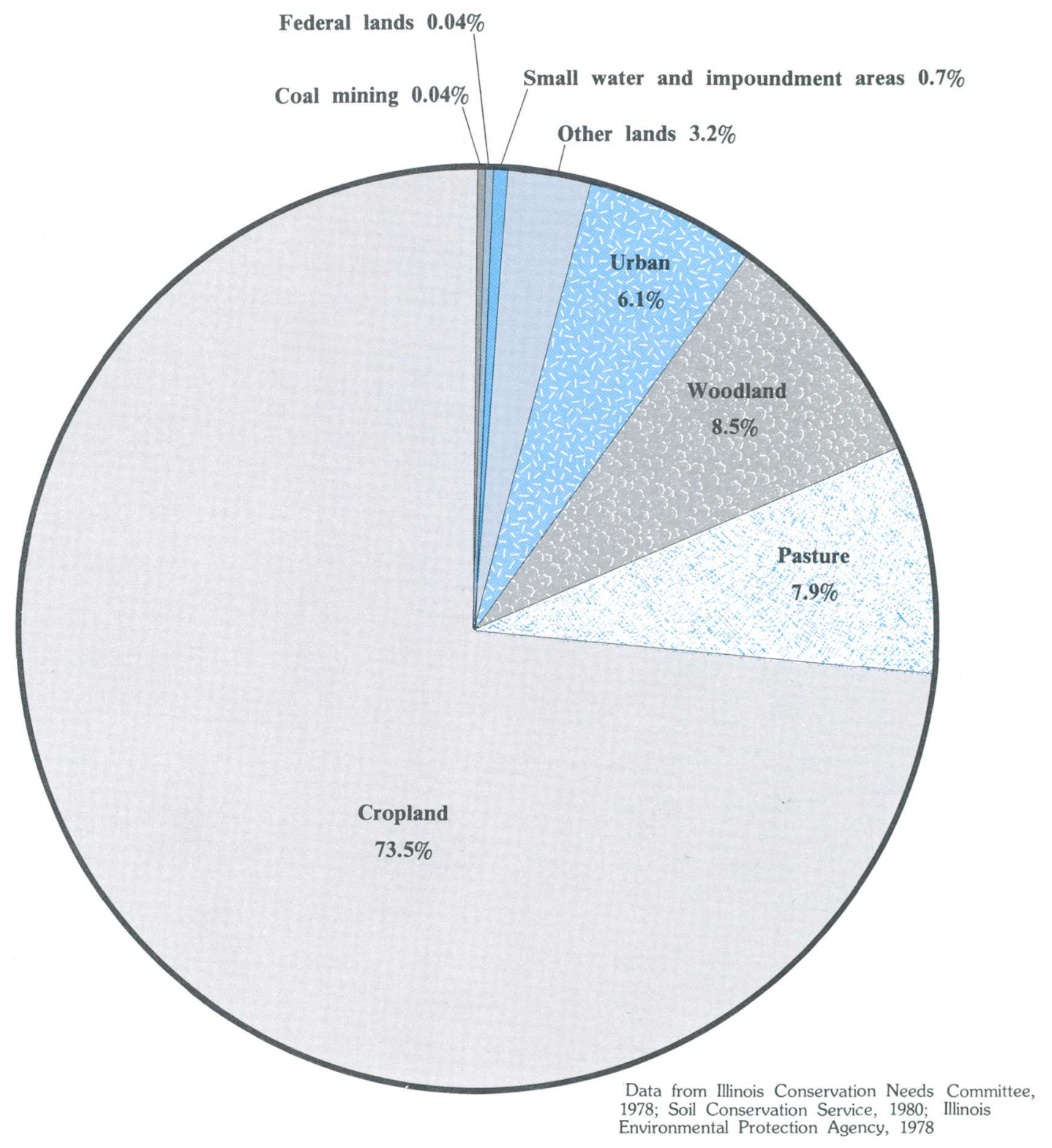

Figure 5.0-1 Land-use distribution. 


\title{
6.0 WATER USE
}

\section{Surface Water is the Major Source of Water in Area 28}

\author{
Ninety-six percent of the water used is obtained from surface-water sources, \\ with the remaining 4 percent drawn from ground-water sources.
}

Total water withdrawal in Area 28 was 1,341 million gallons per day (Mgal/d) in 1978 (Kirk and others, 1979). About $55.0 \mathrm{Mgal} / \mathrm{d}$ (4 percent) was from ground water (fig. 6.0-1). Of the total amount of water withdrawn, 93 percent $(1,245 \mathrm{Mgal} / \mathrm{d})$ was used for industry, 0.1 percent $(0.5 \mathrm{Mgal} / \mathrm{d})$ was used for mineral extraction, 4.6 percent $(61.4 \mathrm{Mgal} / \mathrm{d})$ was used for public supply, 2.4 percent $(31.9 \mathrm{Mgal} / \mathrm{d})$ was used for rural supplies (domestic, livestock, and irrigation), and 0.1 percent $(1.9 \mathrm{Mgal} / \mathrm{d})$ was used for fish and wildlife management.

There are 16 lakes in the area used for recreation (table 6.0-1). Six of the lakes are also used for potable water supply and four of the lakes also provide cooling water (Illinois Environmental Protection Agency, 1978, p. 134-159). There are 78 potential reservoir sites in the area (Dawes and Terstriep, 1966). 


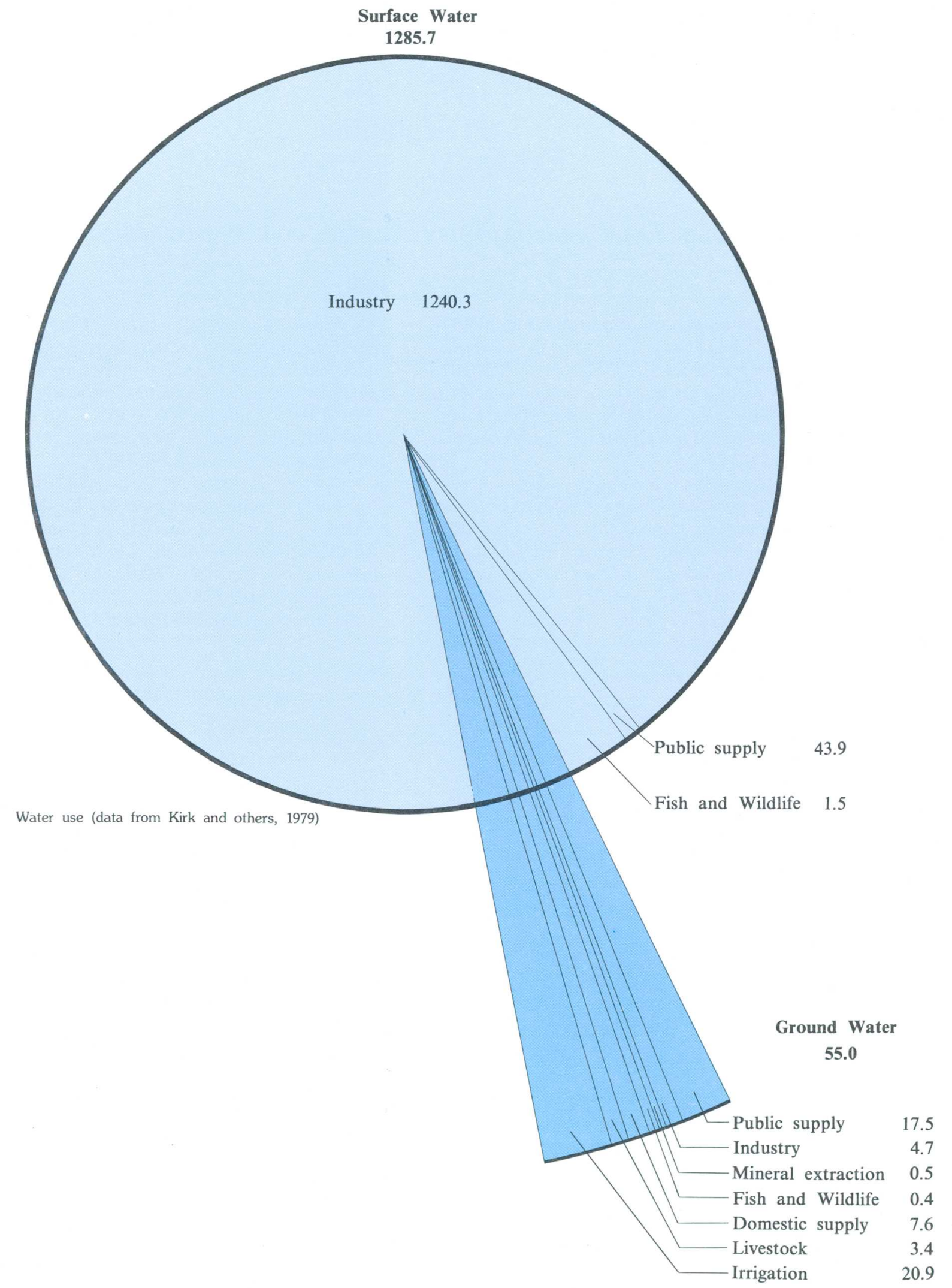

Figure 6.0-1 Water use, 1978, in million gallons per day.
Table 6.0-1 Lakes of Area 28.

\begin{tabular}{|c|c|c|}
\hline Lakes by county & $\begin{array}{l}\text { Surface area } \\
\quad \text { (acres) }\end{array}$ & water use \\
\hline $\begin{array}{l}\text { Cass: } \\
\quad \text { Sanganois Conservation Area }\end{array}$ & 600 & Recreation \\
\hline $\begin{array}{l}\text { Champaign: } \\
\text { Lake of the Woods }\end{array}$ & 25.5 & Recreation \\
\hline $\begin{array}{l}\text { Christian: } \\
\text { Kincaid City Lake } \\
\text { Lake Taylorville } \\
\text { Sangchris Lake }\end{array}$ & $\begin{array}{l}30.7 \\
1,148 \\
2,165\end{array}$ & $\begin{array}{l}\text { Rec., P.W.s. } \\
\text { Do. } \\
\text { Rec., C.w.P }\end{array}$ \\
\hline $\begin{array}{l}\text { De witt: } \\
\text { Clinton Lake } \\
\text { Weldon Springs Lake }\end{array}$ & $\begin{array}{l}4,260 \\
29.4\end{array}$ & $\begin{array}{l}\text { Rec., C.W.P. } \\
\text { Recreation }\end{array}$ \\
\hline $\begin{array}{l}\text { Macon: } \\
\text { Lake Decatur }\end{array}$ & 3,093 & Rec., P.W.S., C.W.P. \\
\hline $\begin{array}{l}\text { Mason: } \\
\text { Crane Lake } \\
\text { Ingram Lake } \\
\text { Otter Lake }\end{array}$ & $\begin{array}{r}756 \\
1,283 \\
289\end{array}$ & $\begin{array}{l}\text { Recreation } \\
\text { Do. } \\
\text { Do. }\end{array}$ \\
\hline $\begin{array}{l}\text { McLean: } \\
\text { Dawson Lake }\end{array}$ & 150 & Recreation \\
\hline $\begin{array}{l}\text { Menard: } \\
\text { Lake Petersburg }\end{array}$ & 190 & Recreation \\
\hline $\begin{array}{l}\text { Sangamon: } \\
\text { Lake Springfield } \\
\text { Loami City Lake } \\
\text { New Berlin Public water Supply }\end{array}$ & $\begin{array}{r}4,024 \\
4.5 \\
4.0\end{array}$ & $\begin{array}{l}\text { Rec., P.W.s., C.W.P. } \\
\text { Rec., p.W.s. } \\
\text { Do. }\end{array}$ \\
\hline
\end{tabular}

$\begin{aligned} \text { Rec. } & =\text { Recreation } \\ \text { P.w.S. } & \text { Public wate }\end{aligned}$

upply

C.W.P. $=$ Cooling water for powerplant 


\subsection{PRECIPITATION}

\section{Precipitation}

\section{Mean annual precipitation in Area 28 ranges from 35 to 38 inches, about 60 percent of which occurs between April and September.}

The mean annual precipitation ranges from 35 to 38 inches (fig. 7.0-1). February is the driest month followed closely by December. The wettest months generally are May and June. About 60 percent of the annual precipitation occurs between April and September and is produced mostly by spring and summer thunderstorms.

The mean annual snowfall ranges from 18 inches along the southeastern edge of the area to 24 inches in the northernmost part of the area (fig. 7.0-2). The cold winters and high winds produce severe weather conditions, which include below $0^{\circ} \mathrm{F}$ wind-chill temperatures and reduced visibility. Freezing rain and sleet occur on an average of 10 to 12 days per year (Dawes and Terstriep, 1966).
The 24-hour rainfall amount that can be expected to be equaled or exceeded on the average of once in 2 years ranges from 3.0 inches in the northeastern part of the area to 3.3 inches in the southwestern part (fig. 7.0-3) (Herschfield, 1961). Rainfall amounts that can be expected for various frequencies and durations are given in table 7.0-1.

Daily precipitation records for Illinois are published by the National Oceanic and Atmospheric Administration (NOAA), Environmental Data and Information Service, National Climatic Center, Asheville, North Carolina 28801. NOAA also publishes hourly precipitation data. 


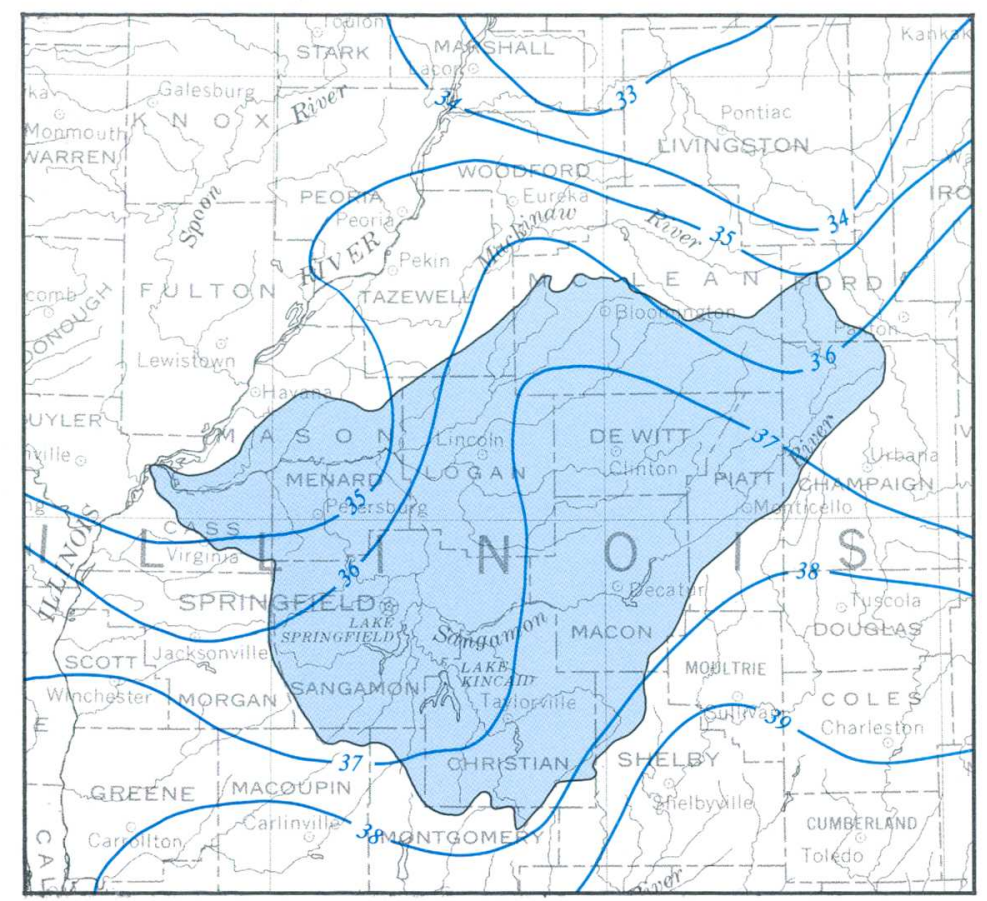

Figure 7.0-1 Mean annual precipitation in the study area (shade), in intes (from Dawes and Terstriep, 1966).

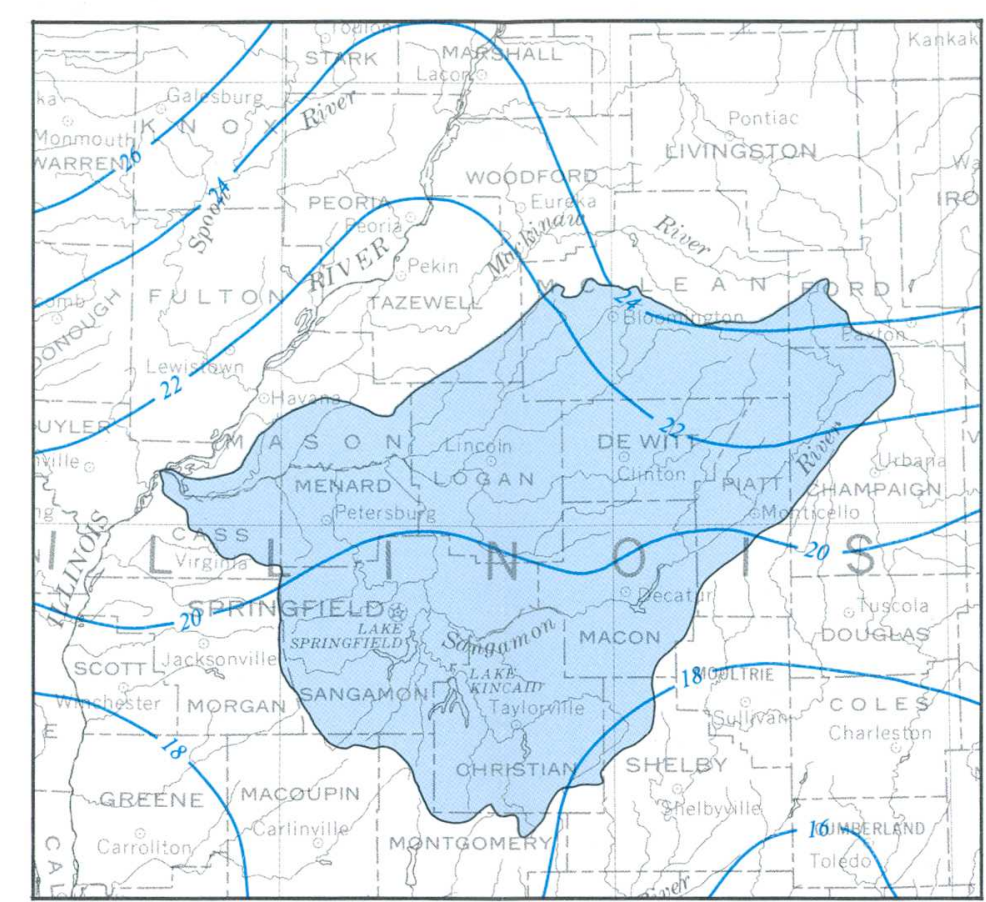

Figure 7.0-2 Mean annual snowfall in the study area (shaded), in inches (from Dawes and Terstriep, 1966).

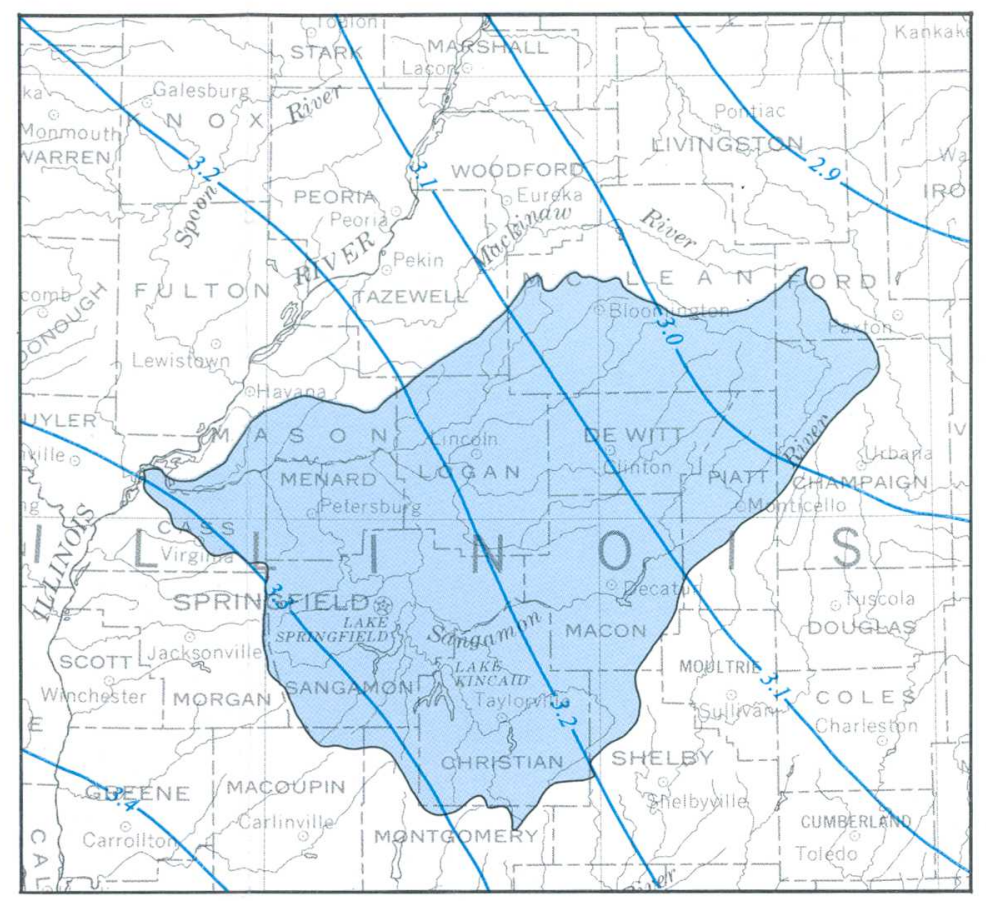

Figure 7.0-3 Two-year, 24-hour rainfall in the study area (shaded), in inches (from Herschfield, 1961).

Table 7.0-1 Precipitation duration-frequency values, in inches

\begin{tabular}{|c|c|c|c|c|c|}
\hline \multirow{3}{*}{$\begin{array}{l}\text { Frequency } \\
\text { (years) }\end{array}$} & \multicolumn{5}{|c|}{$\begin{array}{l}\text { 30-, 60-minute values from Frederick and others, 1977; } \\
\text { 12-, and 24-hour values from Hershfield, 1961] }\end{array}$} \\
\hline & \multicolumn{5}{|c|}{$\begin{array}{c}\text { Duration } \\
\text { (time) }\end{array}$} \\
\hline & 10 minute & 30 minute & 60 minute & 12 hour & 24 hour \\
\hline 2 & 0.70 & 1.18 & 1.50 & 2.80 & 3.20 \\
\hline 5 & 0.85 & 1.48 & 1.91 & 3.50 & 4.00 \\
\hline 10 & 0.96 & 1.70 & 2.20 & 4.00 & 4.50 \\
\hline 25 & 1.11 & 2.00 & 2.61 & 4.50 & 5.20 \\
\hline 50 & 1.23 & 2.23 & 2.93 & 5.00 & 5.90 \\
\hline 100 & 1.36 & 2.47 & 3.25 & 5.60 & 6.40 \\
\hline
\end{tabular}




\subsection{SURFACE-WATER QUANTITY \\ 8.1 Mean Annual Streamflow}

\section{Mean Annual Flow can be Estimated}

\section{Mean annual streamflow is computed at gaging stations and can be estimated at ungaged sites in the study area.}

Area 28 has 28 gaging stations (fig. 8.1-1) with more than 1 year of daily streamflow records. Table $8.1-1$ is a list of 12 stations with less than 20 years of streamflow record and table 8.1-2 is a list of 16 stations with more than 20 years of streamflow records. Each station has a computed mean annual streamflow based on existing records.

Mean annual streamflow is estimated at ungaged sites using the equation $\mathrm{Qa}=0.677 \mathrm{~A}^{0.999}$, where mean annual streamflow $(\mathrm{Qa})$ is in cubic feet per second and the drainage area (A) is in square miles. This equation is derived from a regression analysis using the 16 gaging-station records found in table 8.1-2 which have an average of 34 years of streamflow record and have drainage areas ranging from 11 to 5,093 square miles. The standard error is $0.042 \mathrm{log}$ units or +10.3 and -9.3 percent. Figure $8.1-2$ shows this relation.

Mean annual streamflow is dependent on drainage area, soil characteristics, mean annual precipitation, area of lakes and ponds, area of forests, elevation, and stream length and slope as described by Sieber (1970). Drainage area is the most significant and only variable needed to adequately estimate the mean annual streamflow in the Sangamon River basin. The drainage area can be determined from topographic maps.

All surface-water stations are listed in section 13.0. The U.S. Geological Survey 8-digit station number and the years of record are included along with the station location description. 


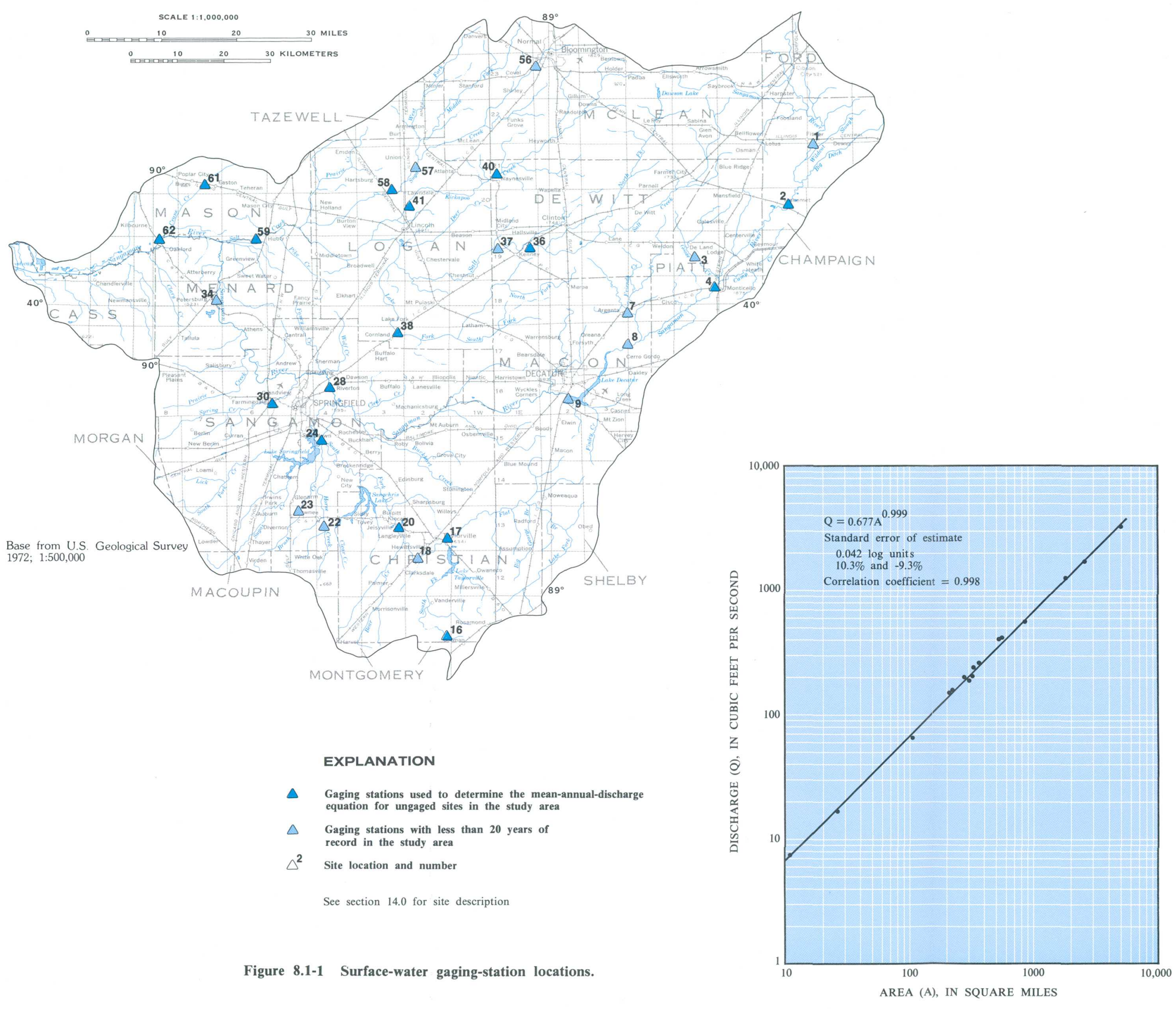

Figure 8.1-2 Mean-annual streamflow.
Table 8.1-1 Gaging stations in the study are

\begin{tabular}{|c|c|c|c|c|}
\hline $\begin{array}{l}\text { Map } \\
\text { site } \\
\text { number }\end{array}$ & Station name & $\begin{array}{c}\text { Drainage } \\
\text { area } \\
\left(\min ^{2}\right)\end{array}$ & $\begin{array}{c}\text { Mean } \\
\text { annual } \\
\text { discharges } \\
(\mathrm{ft} / \mathrm{s})\end{array}$ & $\begin{array}{l}\text { No. of } \\
\text { years } \\
\text { of } \\
\text { record }\end{array}$ \\
\hline 1 & Sangamon River at Fisher & 240 & 259 & 3 \\
\hline 3 & Goose Creek near De Land & 47.9 & 25.4 & 8 \\
\hline 7 & Friends Creek at Argenta & 111 & 96.3 & 15 \\
\hline 8 & Sangamon River near Oakley & 774 & 331 & 5 \\
\hline 9 & Sangamon River at Take Decatur & 925 & 1,080 & 2 \\
\hline 18 & $\begin{array}{l}\text { South Fork Sanganon Ri ver } \\
\text { near Traylorvil11e }\end{array}$ & 434 & 314 & 3 \\
\hline 22 & Horse Creek at Pawnee & 52.2 & 40.5 & 14 \\
\hline 23 & Brush Creek near Divernon & 32.4 & 21.6 & 8 \\
\hline 34 & Sangamon River at Petersburg & 3,063 & 1,620 & 1 \\
\hline 37 & Salt Creek near Kenney & 390 & 232 & 3 \\
\hline 56 & Sugar Creek near Bloomington & 34.6 & 51.2 & 7 \\
\hline 57 & Sugar Creek near Armington & 314 & 125 & \\
\hline
\end{tabular}

Table 8.1-2 Gaging stations in the study area used

to corte the regional-mean-annual-streamflow equation.

\begin{tabular}{|c|c|c|c|c|}
\hline $\begin{array}{l}\text { Map } \\
\text { site } \\
\text { number }\end{array}$ & station name & $\begin{array}{c}\text { Drainage } \\
\text { area } \\
\left(\operatorname{mi}^{2}\right)\end{array}$ & $\begin{array}{c}\text { Mean } \\
\text { annual } \\
\text { discharge } \\
(\mathrm{st} / \mathrm{t} / \mathrm{s})\end{array}$ & $\begin{array}{l}\text { No. of } \\
\text { years } \\
\text { of } \\
\text { record }\end{array}$ \\
\hline 2 & Sangamon River at Mahomet & 362 & 261 & 30 \\
\hline 4 & Sangamon River at Monticello & 550 & 401 & 71 \\
\hline 16 & $\begin{array}{l}\text { South Fork Sanganon River } \\
\text { near Nokomis }\end{array}$ & 11 & 7.25 & 24 \\
\hline 17 & Flat Branch near Taylorville & 276 & 198 & 32 \\
\hline 20 & $\begin{array}{l}\text { South Frork Sangamon River } \\
\text { at Kincaid }\end{array}$ & 562 & 408 & 31 \\
\hline 24 & $\begin{array}{l}\text { South Fork Sangamon River } \\
\text { near Rochester }\end{array}$ & 867 & 558 & 32 \\
\hline 28 & Sangamon River at Riverton & 2,618 & 1,695 & 46 \\
\hline 30 & Spring Creek at Springfield & 107 & 64.8 & 32 \\
\hline 36 & Salt Creek near Rowell & 335 & 237 & 35 \\
\hline 38 & Lake Fork near cornland & 214 & 147 & 33 \\
\hline 40 & Kickapoo Creek at Waynesville & 227 & 155 & 33 \\
\hline 41 & Kickapoo Creek near Linncoln & 306 & 187 & 27 \\
\hline 58 & Sugar creek near Hartsburg & 333 & 197 & 27 \\
\hline 59 & Salt creek near Greenview & 1,804 & 1,245 & 40 \\
\hline 61 & Crane creek near Easton & 26.5 & 16.5 & 26 \\
\hline 62 & Sangamon River near oakford & 5,093 & 3,261 & 54 \\
\hline
\end{tabular}




\subsection{SURFACE-WATER QUANTITY--Continued \\ 8.2 Low Flow}

\section{Low Flow Values Differ Widely Throughout Area}

\section{Low-flow values are low in the southern and eastern parts of the area and relatively high in the northwestern part.}

The low-flow discharge of a stream is used to determine its ability to dilute contaminated wastewater which can originate from city or industrial effluent, mine waste runoff, or contaminated ground-water seeps. The 7-day, 10-year low flow $\left(\mathrm{M}_{7,10}\right)$ is the common index used and referred to in environmental laws. It is the lowest average rate of flow or discharge for 7 consecutive days expected to occur once in a 10-year period.

The 7-day, 10-year low flow $\left(\mathrm{M}_{7,10}\right)$ for 17 continuous-record gaging stations is presented in table 8.2-1. The values range from 0.02 to 145 cubic feet per second $\left(\mathrm{ft}^{3} / \mathrm{s}\right)$. In terms of discharge per square mile, the values range from 0.00018 to $0.04189 \mathrm{ft}^{3} / \mathrm{s}$. Figure 8.2-1 shows ranges of low flow values and indicates that the higher values occur in the northwestern part and the lower values all occur along the eastern and southern parts of the area in the Sangamon River basin upstream from Springfield.
A log-Pearson Type III frequency distribution analysis for each station record was used to determine the low-flow values. The following regional regression equation was developed to estimate the low flow at ungaged sites (D. M. Mades, written commun., 1983):

$$
M_{7,10}=10^{-8} A^{2.72} S^{2.15}
$$

The standard error is $0.48 \log$ units or +202 and -67 percent. The $M_{7,10}$ is the 7-day, 10-year low flow in cubic feet per second per square mile, and $A$ is the drainage area in square miles. $\mathrm{S}$ is the river-channel slope based on the difference in altitude divided by the distance between points 10 and 85 percent of the total distance measured along the low-water channel from the site to the basin divide and is in feet of fall per mile of channel. 


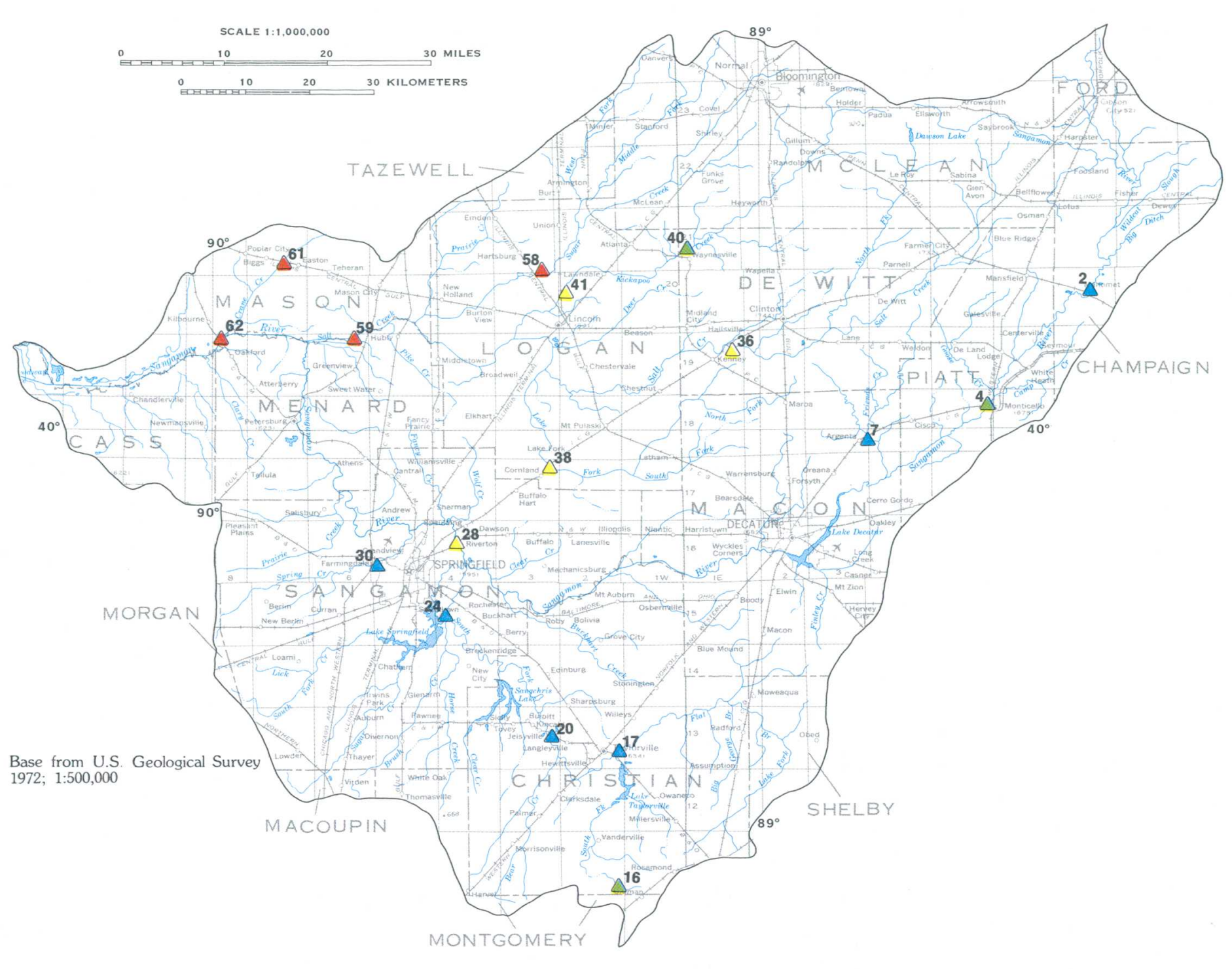

EXPLANATION

Low flow at gaging stations

$\Delta \quad$ Less than $0.002 \mathrm{ftt}^{3} / \mathrm{sec}$. $/ \mathrm{sq}$. mi.

$\Delta \quad 0.002$ to $0.005 \mathrm{ft}^{3} /$ /sec. /sq. mi.

$\triangle \quad 0.005$ to $0.020 \mathrm{ft}^{3} / \mathrm{sec}$. $/ \mathrm{sq}$. mi.

$\triangle \quad$ Greater than $0.020 \mathrm{ft}^{3}$. /sec. / /sq. mi.

$\triangle^{7} \quad$ Site and number

See section 14.0 for site description
Table 8.2-1 Lowflow, 7-day, 10-year $(M 7,10)$ at study area gaging stations.

\begin{tabular}{|c|c|c|c|c|c|}
\hline $\begin{array}{l}\text { Map } \\
\text { site } \\
\text { number }\end{array}$ & Station name & $\begin{array}{c}\mathrm{M}_{7}, 10 \\
\left(\mathrm{ft}^{3} / \mathrm{s}\right) \\
\end{array}$ & $\begin{array}{c}\mathrm{M}_{7,10} \text { per } \\
\text { square mile } \\
{\left[\left(\mathrm{ft}^{3} / \mathrm{s}\right) / \mathrm{mi}^{2}\right]}\end{array}$ & $\begin{array}{c}\text { Drainage } \\
\text { area } \\
\left(\mathrm{mi}^{2}\right)\end{array}$ & $\begin{array}{c}\text { Slope } \\
\text { (ft/mi) }\end{array}$ \\
\hline 2 & Sangamon River at Mahomet & 0.53 & 0.001 & 362 & 3.59 \\
\hline 4 & Sangamon River at Monticello & 2.47 & .005 & 550 & 2.75 \\
\hline 7 & Friends Creek at Argenta & .02 & .0002 & 111 & - \\
\hline 16 & South Fork Sangamon River near Nokomis & .053 & .005 & 11.0 & 18.8 \\
\hline 17 & Flat Branch near Taylorville & .37 & .001 & 276 & 2.01 \\
\hline 20 & South Fork Sangamon River at Kincaid & 1.10 & .002 & 562 & 2.01 \\
\hline 24 & South Fork Sangamon River near Rochester & .90 & .001 & 867 & 1.32 \\
\hline 28 & Sangamon River at Riverton & 20.4 & .008 & 2,618 & 1.48 \\
\hline 30 & Spring Creek at Springfield & .04 & .0004 & 107 & 5.39 \\
\hline 36 & Salt Creek near Rowell & 2.83 & .008 & 335 & 2.59 \\
\hline 38 & Lake Fork near Cornland & 2.54 & .012 & 214 & 4.65 \\
\hline 40 & Kickapoo Creek at waynesville & .74 & .003 & 227 & 6.23 \\
\hline 41 & Kickapoo Creek near Lincoln & 2.14 & .007 & 306 & 5.12 \\
\hline 58 & Sugar Creek near Hartsburg & 6.87 & .021 & 333 & 5.76 \\
\hline 59 & Salt Creek near Greenview & 69.2 & .038 & 1,804 & 2.20 \\
\hline 61 & Crane Creek near Easton & 1.11 & .042 & 26.5 & 2.16 \\
\hline 62 & Sangamon River near Oakford & 145 & .028 & 5,093 & 1.27 \\
\hline
\end{tabular}

Figure 8.2-1 Gaging stations with calculated 7-day, 10-year low flow values. 


\subsection{SURFACE-WATER QUANTITY-Continued 8.3 Floodflow}

\section{Floodflow can be Estimated}

\section{Floodflow and peak discharge can be estimated by using equations developed from many years of streamflow records.}

Floodflow in a stream occurs when there is excessive rainfall and or rapid snowmelt. Regional floodflow can be estimated at ungaged sites using equations developed from streamflow records. Figure 8.3-1 shows the location of 17 gaging stations with more than 10 years of streamflow data used to develop the regional floodflow equations.

To estimate the 7-day, 10-year floodflow $\left(\mathrm{V}_{7,10}\right)$, use the equation:

$$
\mathrm{V}_{7,10}{ }^{5} 16.6 \mathrm{~A}^{0.92}
$$

The standard error is 0.0767 log units or -19.3 and -16.2 percent. The highest 7 -consecutive-day mean discharge in cubic feet per second expected to be exceeded at intervals averaging 10 years, is the 7-day, 10-year floodflow. The drainage area (A) is measured in square miles. The 7-day, 10-year floodflow for each gaging station is plotted against its corresponding drainage area as shown in figure 8.3-2.

The peak discharge $\left(\mathrm{Q}_{\mathrm{T}}\right)$ for the study area can be estimated using the equations defined by Curtis (1977) as follows:

$$
\begin{array}{lll}
Q_{2}{ }^{5} 42.7 & A^{0.776} \mathrm{~S}^{0.466}(\mathrm{I}-2.5)^{0.834} \text { Af } \\
\mathrm{Q}_{10}{ }^{5} 90.8 \mathrm{~A}^{0.767} \mathrm{~S}^{0.494}(\mathrm{I}-2.5)^{0.833} & \text { Af } \\
\mathrm{Q}_{50}{ }^{5} 134 & \mathrm{~A}^{0.763} \mathrm{~S}^{0.510}(\mathrm{I}-2.5)^{0.836} & \text { Af } \\
\mathrm{Q}_{100}{ }^{5} 152 & \mathrm{~A}^{0.762} \mathrm{~S}^{0.515}(\mathrm{I}-2.5)^{0.836} & \text { Af }
\end{array}
$$

For the peak discharge $\left(Q_{T}\right), T$ is the recurrence interval in years. Therefore $Q_{2}, Q_{10}, Q_{50}$, and $Q_{100}$ can be expected to be equaled or exceeded once in any $2-, 10-, 50-$, and 100-year period, respectively. The peak discharge is measured in cubic feet per second. The drainage area $(\mathrm{A})$ is in square miles. The river channel slope (S) is measured from the 10 to 85 percent points on the low-water channel as measured from the site to the basin divide. The rainfall intensity (I) is the maximum 24-hour rainfall, in inches, expected to be exceeded at intervals averaging 2 years in length. The areal factor (Af) for the entire study area is 0.85 (Curtis, 1977). Across the Sangamon River basin, rainfall intensity increases from 3.0 inches in the northeast to 3.3 inches in the southwest. The value of rainfall intensity used in the above equation should be the average for the drainage basin under consideration (Curtis, 1977).

The 7-day, 10-year floodflow and 10-year peak discharge equations are based on records from U.S. Geological Survey streamflow gaging stations having an average of 32 years of record. The drainage areas range from 11 to 5,093 square miles.

Table 8.3-1 shows the $Q_{2}, Q_{10}, Q_{50}$, and $Q_{100}$ for gaging stations in study area (Curtis, 1977). 


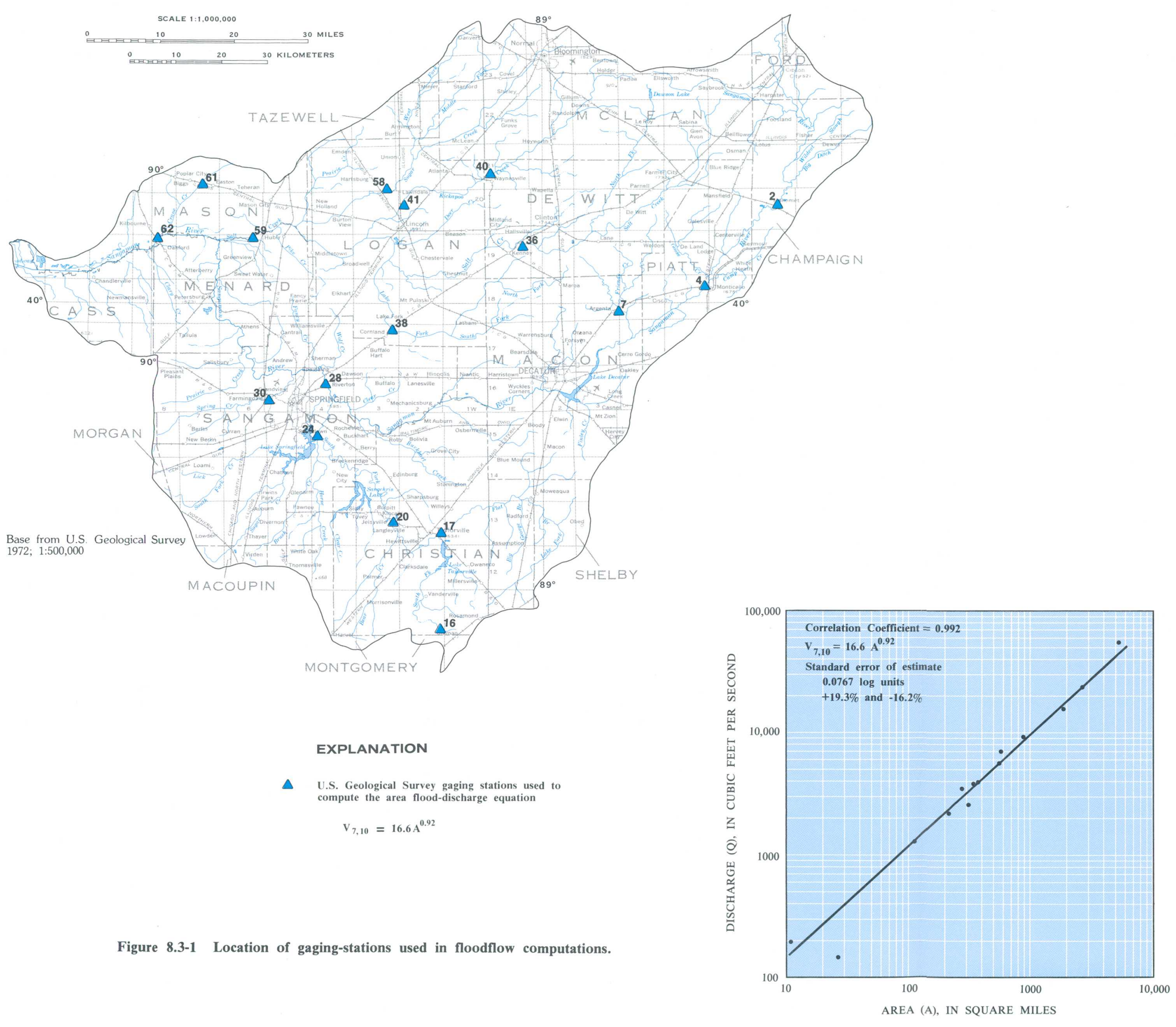

Table 8.3-1 Area gaging station peak discharge and floodflow, in cubic feet per second, calculated from station record.

\begin{tabular}{|c|c|c|c|c|c|c|}
\hline \multirow{2}{*}{$\begin{array}{l}\text { Map } \\
\text { site } \\
\text { number }\end{array}$} & \multirow{2}{*}{$\begin{array}{c}\text { Drainage } \\
\text { area } \\
\left(\mathrm{mi}^{2}\right)\end{array}$} & \multicolumn{4}{|c|}{ Peak discharge } & \multirow{2}{*}{$\begin{array}{c}\text { Flood- } \\
\text { flow } \\
\mathrm{v}_{7}, 10 .\end{array}$} \\
\hline & & $\mathrm{Q2}_{2}$ & $Q_{10}$ & 250 & $Q_{100}$ & \\
\hline 2 & 362 & 4,180 & 9,100 & 13,600 & 15,500 & 3,930 \\
\hline 4 & 550 & 5,140 & 11,400 & 17,200 & 19,600 & 5,550 \\
\hline 7 & 111 & (a) & (a) & (a) & (a) & 1,260 \\
\hline 16 & 11.0 & 1,050 & 2,670 & 4,270 & 4,920 & 193 \\
\hline 17 & 276 & 3,630 & 8,580 & 13,300 & 15,100 & 3,410 \\
\hline 20 & 562 & 4,680 & 11,000 & 17,300 & 20,100 & 6,950 \\
\hline 24 & 867 & 5,290 & 12,200 & 18,800 & 21,600 & 9,010 \\
\hline 28 & 2,618 & 14,900 & 30,800 & 41,900 & 45,800 & 23,200 \\
\hline 30 & 107 & 1,650 & 4,500 & 7,520 & 8,870 & 1,090 \\
\hline 36 & 335 & 3,810 & 9,930 & 16,400 & 19,300 & 3,770 \\
\hline 38 & 214 & 2,180 & 6,100 & 10,400 & 12,400 & 2,180 \\
\hline 40 & 227 & 3,840 & 8,370 & 12,600 & 14,400 & 2,170 \\
\hline 41 & 306 & 4,270 & 9,230 & 13,900 & 15,800 & 2,580 \\
\hline 58 & 333 & 4,710 & 9,790 & 14,500 & 16,500 & 2,320 \\
\hline 59 & 1,804 & 12,000 & 25,700 & 38,400 & 43,700 & 15,300 \\
\hline 61 & 26.5 & 218 & 529 & 844 & 996 & 145 \\
\hline 62 & 5,093 & 21,100 & 47,700 & 71,800 & 81,700 & 53,100 \\
\hline
\end{tabular}
Figure 8.3-2 Relation of $\mathbf{V}_{7,10}$ floodflow
to drainage area.. 


\subsection{SURFACE-WATER QUANTITY--Continued \\ 8.4 Flow-Duration Curves}

\section{Shapes of Flow-Duration Curves Vary with Geology and Land Use}

\section{Flow-duration curves summarize long-term daily discharge data and flow characteristics.}

A flow-duration curve, which is based on streamflow at a site, is used to show the percentage of time that a specific stream discharge can be expected to be equaled or exceeded. Table 8.4-1 shows discharges that will be equaled or exceeded at various percentages of time. The sites for which flow-duration statistics are given are shown in figure 8.4-1.

Geologic characteristics and land use are the principle factors that determine the shape of the flow-duration curve. A curve with a steep slope indicates highly variable streamflow such as that resulting from rapid surface runoff. Rapid runoff is caused by impervious soils, roads, and terrain. Streams in the upper Sangamon River basin have steep flow-duration curves (fig. 8.4-2). Although the terrain is relatively flat, many drain tiles in agricultural fields provide rapid runoff after percolation of only a few feet. Flow-duration curves for Salt Creek (fig. 8.4-3) reflect the same flow pattern.

The flow-duration curve for Crane Creek (site No. 61) has a more gentle slope and is characteristic of streams with high base flows. The high base flow may be caused by high ground-water discharge or delayed surface runoff such as from reservoir storage (fig. 8.4-4). Crane Creek is located directly over a sand and gravel aquifer which transmits ground water easily. Low flow is as much as 10 times greater in this basin compared to most of the study area. However, the high flows are less in Crane Creek than at other sites in Area 28.

Flow-duration data are used for planning purposes in waste-water treatment, water supply, and flood control.

Table 8.4-1 Flow-duration statistics, in cubic feet per second per square mile.

\begin{tabular}{|c|c|c|c|c|c|c|c|c|c|}
\hline \multirow{2}{*}{$\begin{array}{c}\text { Map } \\
\text { site } \\
\text { number }\end{array}$} & \multirow[b]{2}{*}{ Station name } & \multirow{2}{*}{$\begin{array}{c}\text { Drainage } \\
\text { area } \\
\text { (mi }{ }^{2} \text { ) }\end{array}$} & \multicolumn{7}{|c|}{$\begin{array}{c}\text { Percent of time stream discharge } \\
\text { is equaled or exeeded }\end{array}$} \\
\hline & & & 95 & 90 & 75 & 70 & 50 & 25 & 10 \\
\hline & Upper Sangamon RAver basin & & & & & & & & \\
\hline 2 & Sangamon River at Mahomet & 362 & 0.008 & 0.02 & 0.05 & 0.07 & 0.25 & 0.75 & 1.82 \\
\hline 7 & Friends creek at Argenta & 111 & .0009 & .002 & .05 & .10 & .34 & .99 & 2.16 \\
\hline 17 & Flat Branch near Taylorville & 276 & .001 & .007 & .03 & .05 & .19 & .62 & 1.74 \\
\hline 18 & $\begin{array}{l}\text { South Fork Sangamon River } \\
\text { near Taylorville }\end{array}$ & 434 & .01 & .02 & .07 & .10 & .23 & .67 & 2.28 \\
\hline 24 & $\begin{array}{l}\text { South Fork Sangamon River } \\
\text { near Rochester }\end{array}$ & 867 & .004 & .01 & .04 & .06 & .17 & .61 & 1.73 \\
\hline \multirow[t]{2}{*}{30} & Spring Creek at Springfield & 107 & 0 & 0 & .02 & .04 & .18 & .54 & 1.40 \\
\hline & Salt Creek basin & $:$ & & & & & & & \\
\hline 36 & Salt Creek near Rowell & 335 & 0.02 & 0.03 & 0.07 & 0.10 & 0.27 & 0.78 & 1.76 \\
\hline 38 & Lake Fork near cornland & 214 & .02 & .03 & .06 & .08 & .24 & .70 & 1.68 \\
\hline 40 & Rickapoo Creek at Waynesville & 227 & .01 & .02 & .05 & .07 & .24 & .70 & 1.59 \\
\hline 41 & Rickapoo Creek near Lincoln & 306. & .02 & .02 & .06 & .08 & .23 & .65 & 1.47 \\
\hline \multirow[t]{2}{*}{58} & Sugar creek near Hartsburg & 333 & .04 & .05 & .08 & .10 & .25 & .66 & 1.35 \\
\hline & Lower Sangamon Rdver basin & & & & & & & & \\
\hline 59 & Salt creek near Greenview & 1,804 & 0.05 & 0.07 & 0.10 & 0.14 & 0.33 & 0.83 & 1.66 \\
\hline 61 & Crane Creek near Easton & 26.5 & .10 & .15 & .24 & .27 & .42 & .79 & 1.25 \\
\hline 62 & Sangamon River near Oakford & 5,093 & .04 & .05 & .09 & .12 & .30 & .75 & 1.65 \\
\hline
\end{tabular}




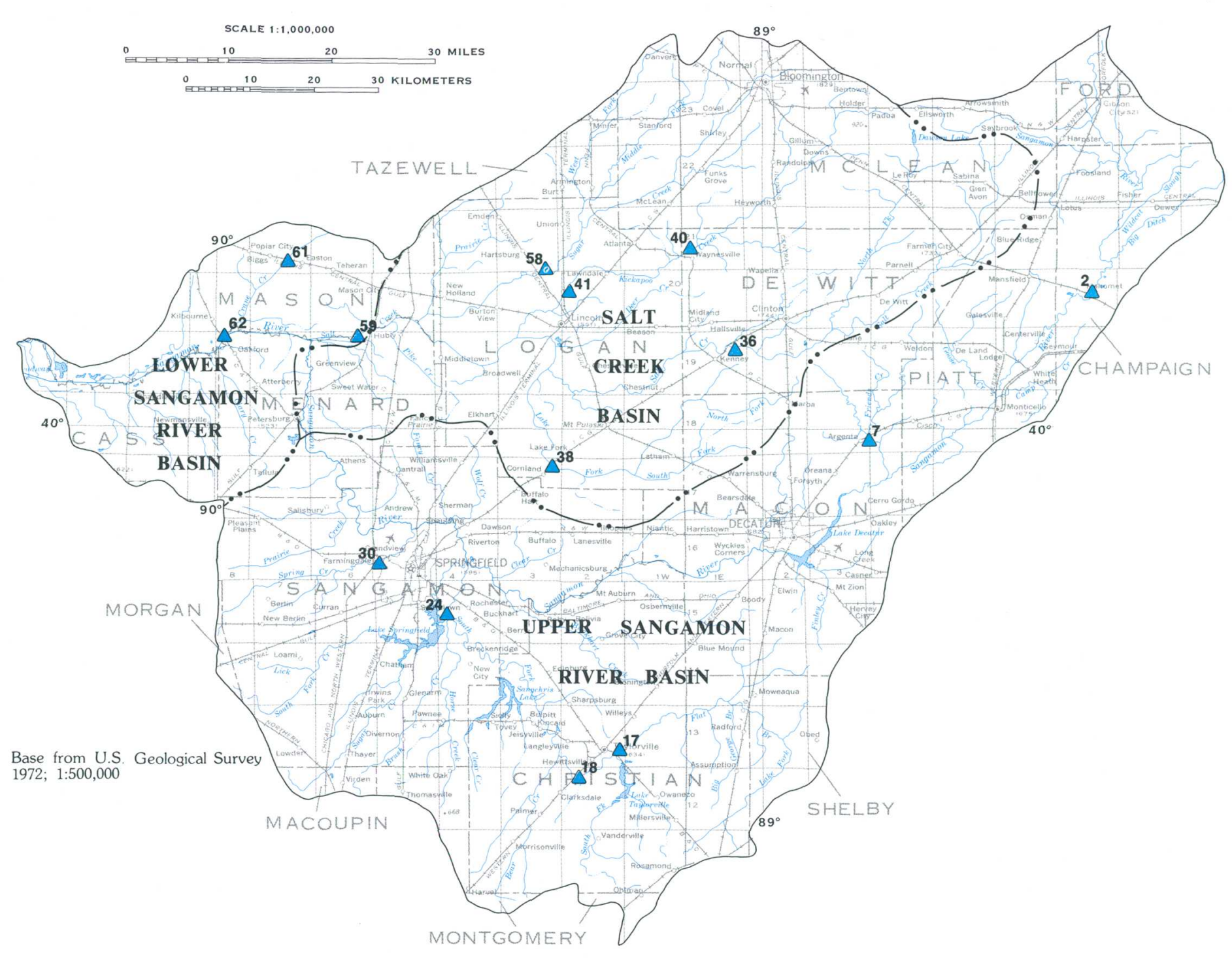

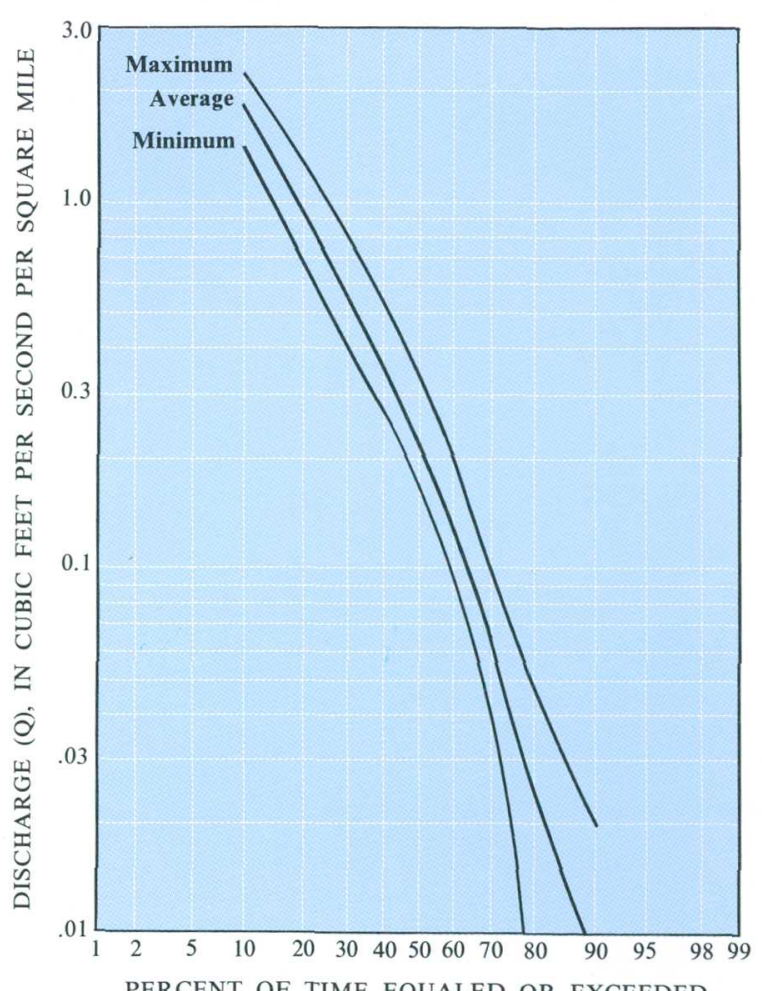

PERCENT OF TIME EQUALED OR EXCEEDED

Figure 8.4-2 Flow duration in upper

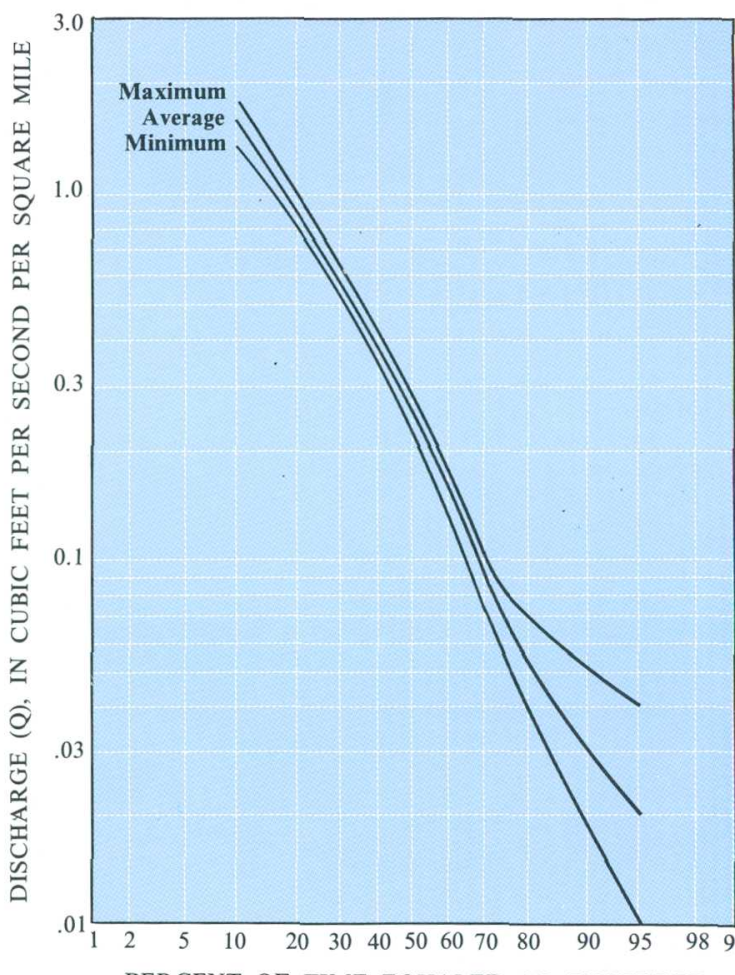

PERCENT OF TIME EQUALED OR EXCEEDED

Figure 8.4-3 Flow duration in

\section{EXPLANATION}

$\triangle \quad \begin{gathered}\text { U.S. Geological Survey } \\ \text { gaging stations used for }\end{gathered}$

flow-duration analysis

_.. - Basin boundaries

Figure 8.4-1 Location of gaging stations used in flow-duration analysis.

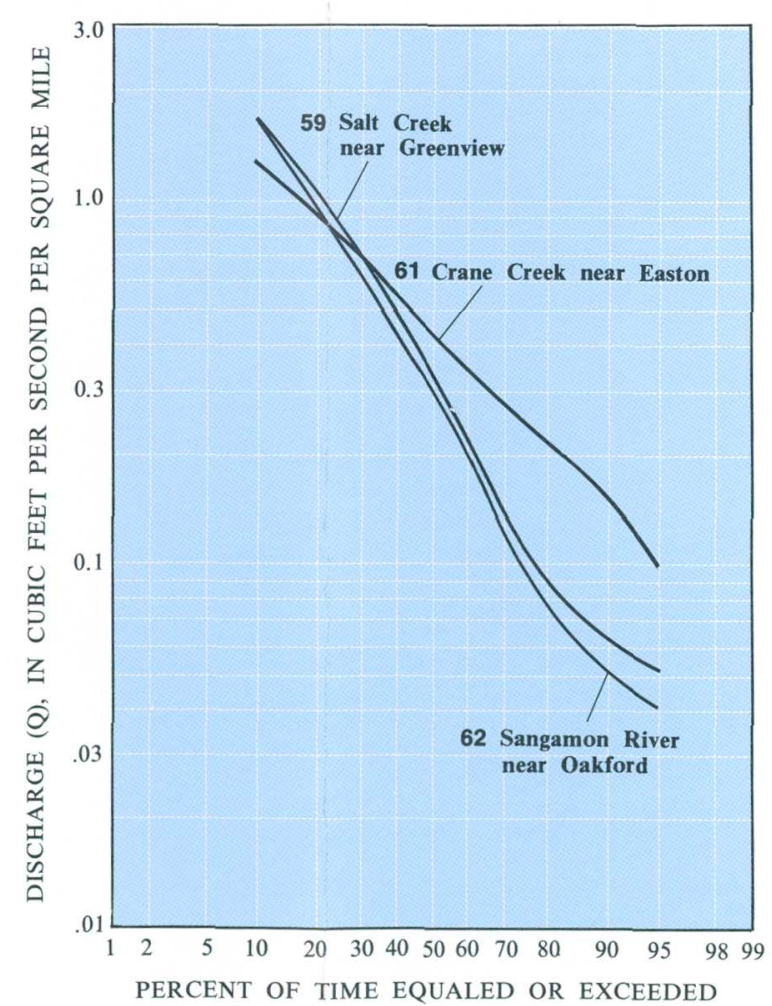

Figure 8.4-4 Flow duration in lower basin. 


\title{
9.0 SURFACE-WATER QUALITY
}

9.1 Available Data

\section{Water-Quality Data Available for Sites Throughout Area}

\author{
Chemical and physical water-quality data were collected by the U.S. Geological \\ Survey, Illinois Environmental Protection Agency, and the Bloomington-Normal \\ Sanitary District at 47 sites throughout the study area.
}

\begin{abstract}
Specific conductance, $\mathrm{pH}$, alkalinity, sulfate, iron, and manganese data are important in assessing the water quality in areas affected by coal mining. The Illinois Environmental Protection Agency collects monthly water-quality samples at 25 sites in Area 28 as part of a statewide ambient waterquality-monitoring network. Synoptic water-quality sampling was done at 24 of the 25 sites plus 9 U.S. Geological Survey sites. Synoptic sampling is collecting samples from various locations within a short period of time. Each of four sets of synoptic samples
\end{abstract}

was collected by the U.S. Geological Survey within a period of 3 days to insure similar streamflow conditions at all sites for each set. The BloomingtonNormal Sanitary District collected samples periodically from 13 sites in and near their cities. Data from four of these sites are used in this report. The water-quality samples from 47 sites (fig. 9.1-1) provide chemical and physical data along with suspended-sediment data for this report. The periods of water-quality record can be found in section 13.0. 


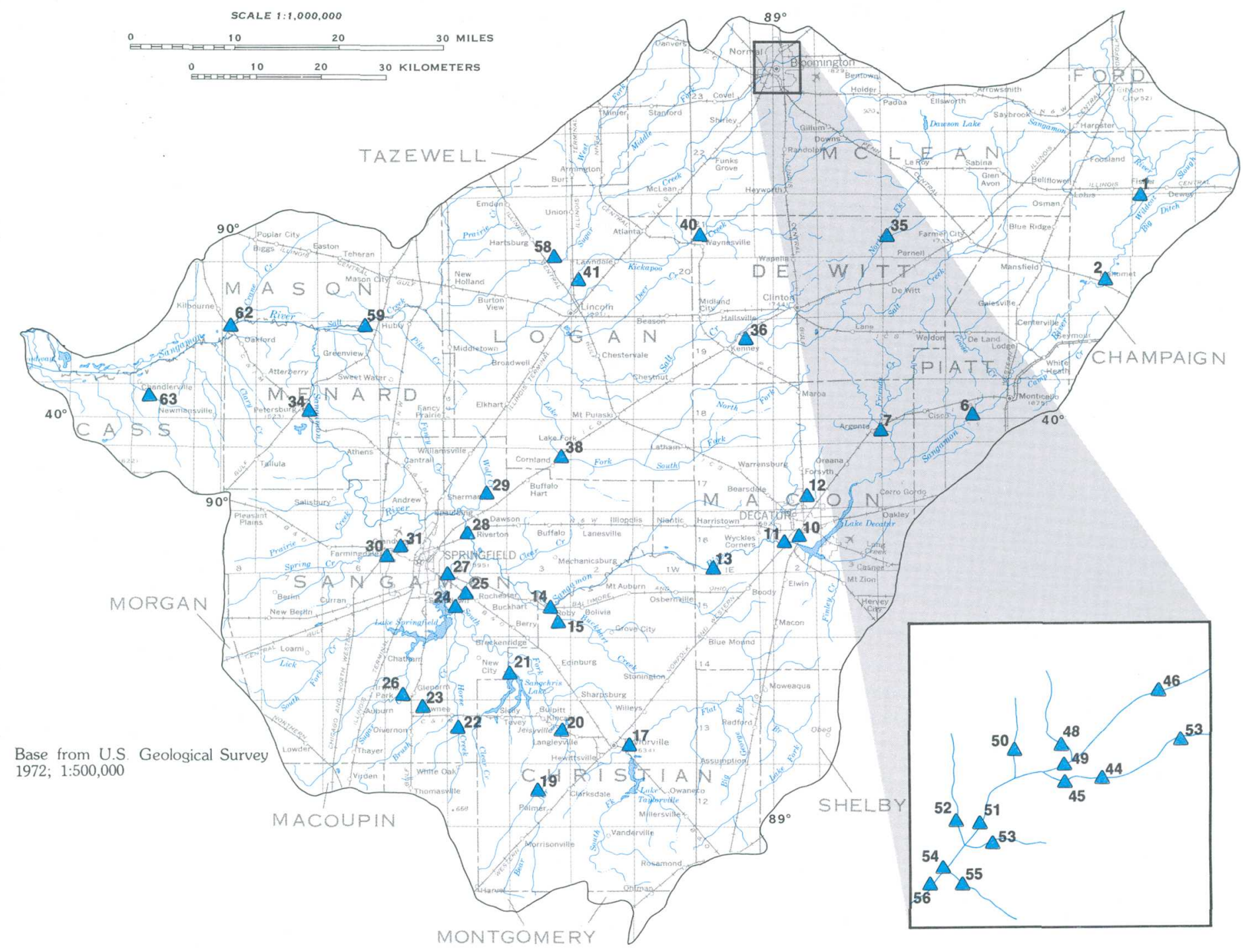

EXPLANATION

$\Delta^{2} \quad$ Water-quality site and number

See section 14.0 for site description

Figure 9.1-1 Location of water-quality sites (see section 14.0 for station names). 


\title{
9.0 SURFACE-WATER QUALITY--Continued \\ 9.2 Specific Conductance and Dissolved Solids
}

\section{Specific Conductance can be Used to Estimate Dissolved-Solids Concentrations}

\author{
Specific conductance and dissolved-solids concentrations varied inversely \\ with water discharge.
}

Electrical conductance is a measure of the ability of a substance to conduct electrical current. Specific electrical conductance, or simply specific conductance, is defined as "the reciprocal of the resistance in ohms, measured between opposite faces of a centimeter cube of an aqueous solution at a specific temperature" (Hem, 1970). In this report, the unit of measurement for specific conductance is the micromho per centimeter at $25^{\circ}$ Celsius $(\mu \mathrm{mho})$. Ranges of average values for 37 sites are indicated in figures 9.2-1 and 9.2-2.

Dissolved solids is a measure of the concentration of dissolved minerals expressed in milligrams per liter of water. Because most dissolved solids are present as ions in natural waters, specific conductance gives an indication of the concentration of dissolved solids.

The relation between specific conductance and dissolved solids at 34 sites is nearly linear as shown in figure 9.2-3. Dissolved-solid concentrations (S) can be estimated from specific conductance $(\mathrm{K})$ with the equation $\mathrm{KA}=\mathrm{S}$. The factor $(\mathrm{A})$ is 0.60 for the study area. For natural streams, A generally ranges from 0.55 to 0.75 with higher values of $\mathrm{A}$ being commonly associated with water containing higher concentrations of sulfate (Hem, 1970).

Measured values of specific conductance ranged from 50 to $5,100 \mu$ mhos (table 9.2-1). Maximum measured dissolved-solids concentration was 3,260 milligrams per liter (table 9.2-2). The higher dissolved-solids concentrations occur during lowflow periods when ground-water discharge is the principle component of streamflow. In general, lower concentrations occur in the spring due to the increased runoff from snowmelt and spring rains which tend to dilute the ground-water inflows. 


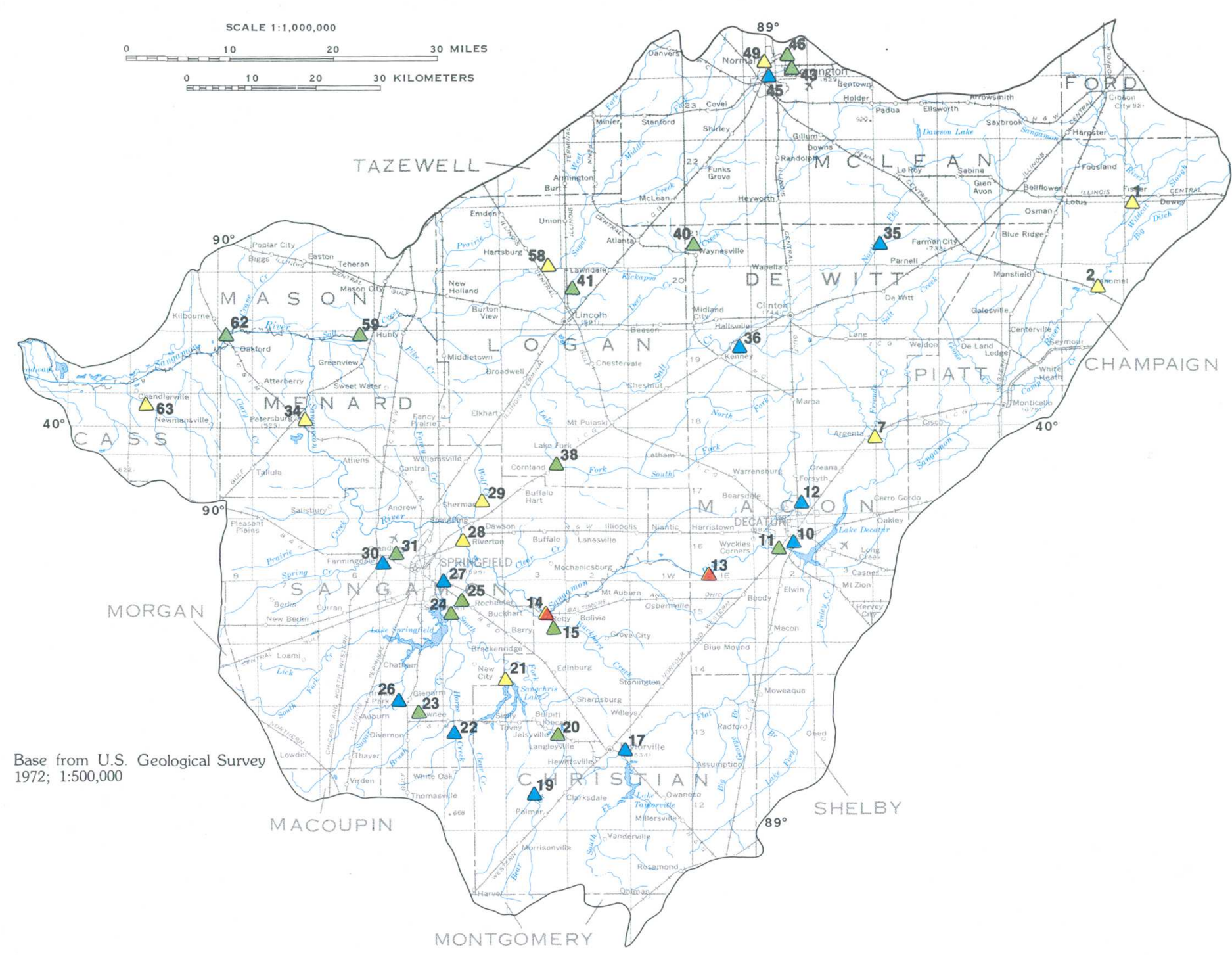

EXPLANATION

\section{verage values for specific conductance
at each site, in micromhos per
centimeter at $25^{\circ}$ Celsius}

$\triangle \quad$ Less than 550

$\triangle \quad 550-700$

$\triangle \quad 701-850$

$\triangle$ Greater than 850

$\partial^{2}$ Site location and number

See section 14.0 for site description
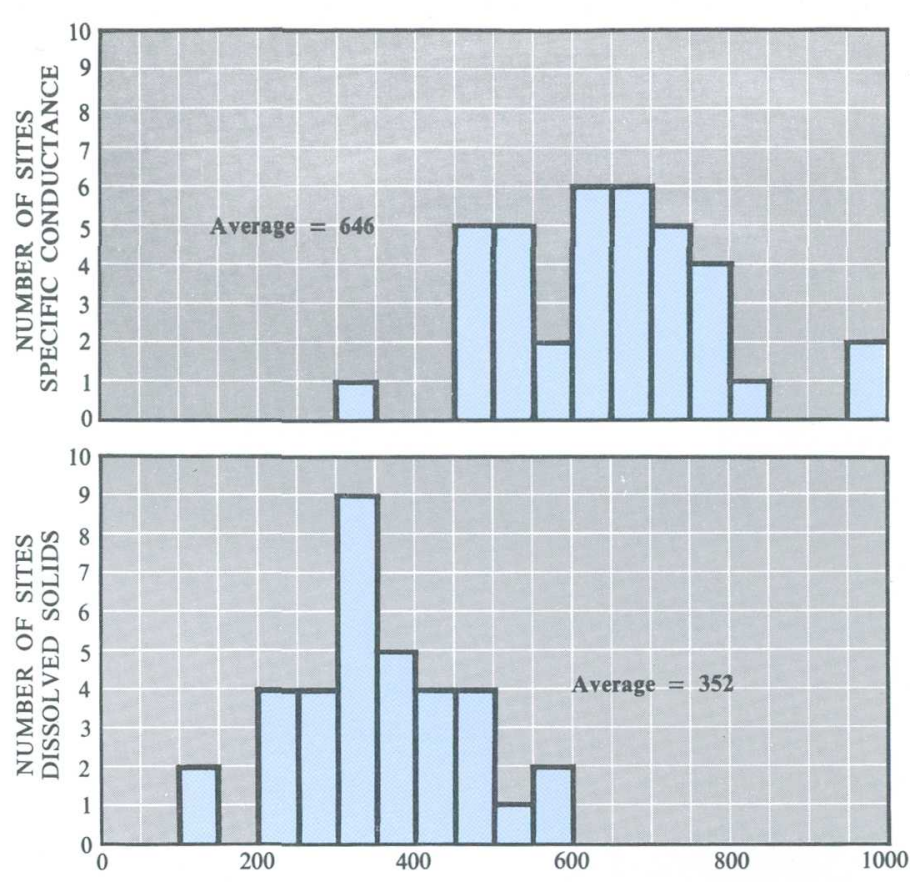

RANGE OF SPECIFIC CONDUCTANCE, IN MICROMHOS,
AND DISSOLVED SOLIDS, IN MILLIGRAMS PER LITER

Figure 9.2-2 Range and frequency distribution of average values of specific conductance and dissolved

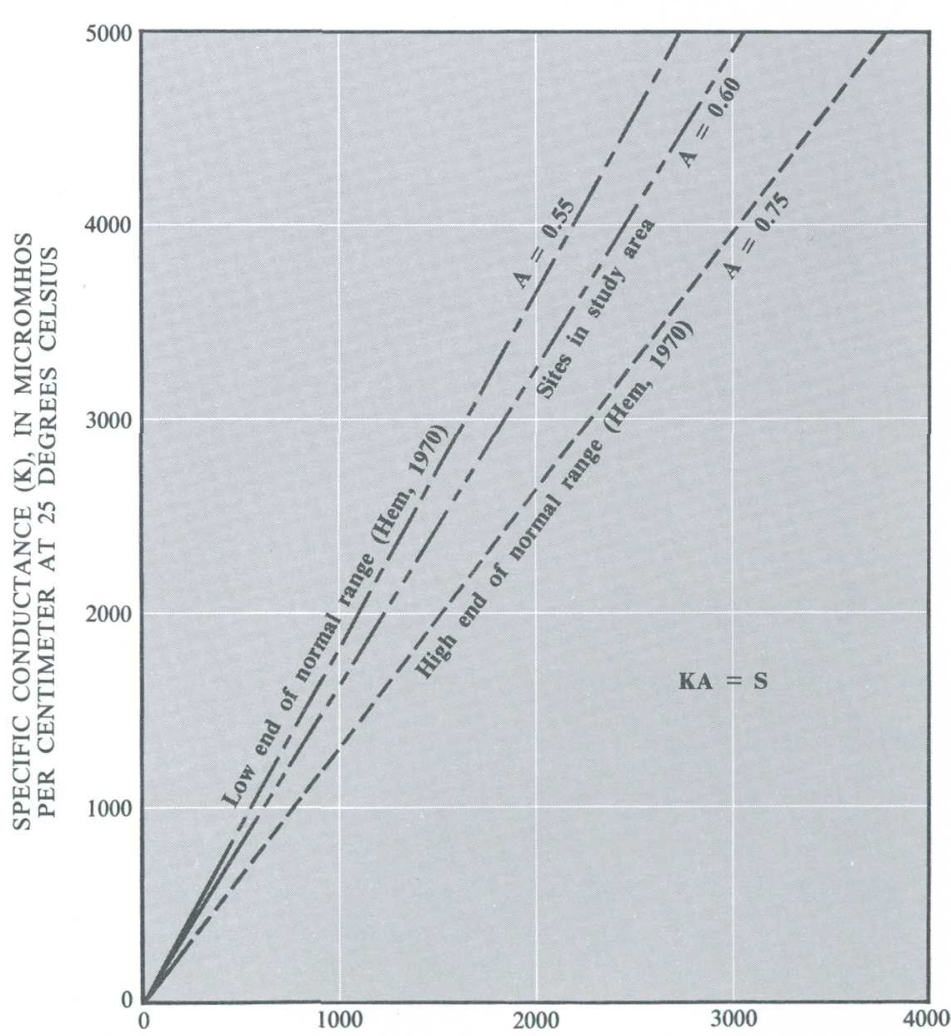

DISSOLVED SOIDS (S), RO MHLIGRAMS PER UTER Figure 9.2-3 $\begin{gathered}\text { Relation between specific conductance } \\ \text { and dissolved solids. }\end{gathered}$
Table 9.2-1 Specific conductance values

\begin{tabular}{|c|c|c|c|c|}
\hline $\begin{array}{c}\text { Map } \\
\text { site } \\
\text { number } \\
\text { numbers }\end{array}$ & $\begin{array}{l}\text { Mumber of } \\
\text { observations }\end{array}$ & \multicolumn{3}{|c|}{ 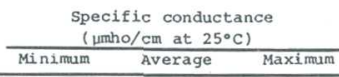 } \\
\hline $\begin{array}{c}2 \\
7 \\
10 \\
11\end{array}$ & $\begin{array}{l}36 \\
11 \\
29 \\
56 \\
56\end{array}$ & $\begin{array}{l}390 \\
600 \\
730 \\
300 \\
300 \\
300\end{array}$ & $\begin{array}{l}750 \\
7190 \\
732 \\
588\end{array}$ & 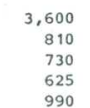 \\
\hline $\begin{array}{l}12 \\
13 \\
13\end{array}$ & $\begin{array}{l}32 \\
70\end{array}$ & $\begin{array}{l}75 \\
320\end{array}$ & $\begin{array}{l}314 \\
993 . \\
993\end{array}$ & $\begin{array}{r}730 \\
2,580\end{array}$ \\
\hline $\begin{array}{l}\text { 点 } \\
17\end{array}$ & $\begin{array}{l}56 \\
1 \\
37\end{array}$ & $\begin{array}{c}330 \\
693 \\
50\end{array}$ & $\begin{array}{l}\begin{array}{l}976 \\
693 \\
539\end{array} \\
539\end{array}$ & $\begin{array}{l}3.1400 \\
6993 \\
9220\end{array}$ \\
\hline $\begin{array}{l}19 \\
20\end{array}$ & $\begin{array}{c}6 \\
53\end{array}$ & $\begin{array}{l}345 \\
90 \\
90\end{array}$ & $\begin{array}{l}486 \\
638\end{array}$ & $\begin{array}{r}661 \\
1,120\end{array}$ \\
\hline 丝2 & $\begin{aligned} 21 \\
2 \\
4\end{aligned}$ & $\begin{array}{l}510 \\
510 \\
445\end{array}$ & $\begin{array}{l}514 \\
509 \\
609\end{array}$ & $\begin{array}{l}1,060 \\
519 \\
717\end{array}$ \\
\hline $\begin{array}{l}24 \\
25\end{array}$ & $\begin{array}{l}6 \\
47\end{array}$ & $\begin{array}{l}245 \\
180\end{array}$ & $\begin{array}{l}595 \\
640 \\
640\end{array}$ & $\begin{array}{c}873 \\
1,350\end{array}$ \\
\hline 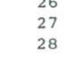 & $\begin{array}{l}33 \\
49\end{array}$ & $\begin{array}{l}295 \\
\text { 2950 } \\
340\end{array}$ & $\begin{array}{l}\text { sit } \\
\text { st1 } \\
717\end{array}$ & $\begin{array}{c}750 \\
1,650 \\
1\end{array}$ \\
\hline $\begin{array}{l}\text { 29 } \\
30 \\
31\end{array}$ & $\begin{array}{r}6 \\
32\end{array}$ & $\begin{array}{l}739 \\
3250 \\
200\end{array}$ & $\begin{array}{l}739 \\
497 \\
604\end{array}$ & 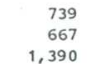 \\
\hline $\begin{array}{l}34 \\
35\end{array}$ & si & $\begin{array}{l}300 \\
\text { s.54 } \\
454\end{array}$ & $\begin{array}{l}780 \\
\text { as } \\
454\end{array}$ & $\begin{array}{l}1,380 \\
1,380 \\
4545\end{array}$ \\
\hline $\begin{array}{l}36 \\
38 \\
40\end{array}$ & $\begin{array}{l}51 \\
54 \\
68 \\
48\end{array}$ & 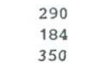 & 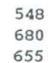 & $\begin{array}{l}835 \\
\text { s50 } \\
\text { sio }\end{array}$ \\
\hline $\begin{array}{l}41 \\
43\end{array}$ & ${ }_{23}^{43}$ & $\begin{array}{l}215 \\
520 \\
520\end{array}$ & $\begin{array}{l}618 \\
660 \\
660\end{array}$ & $\begin{array}{l}700 \\
7900 \\
900\end{array}$ \\
\hline $\begin{array}{l}y_{45}^{45} \\
496\end{array}$ & $\begin{array}{c}185 \\
162 \\
161\end{array}$ & $\begin{array}{c}7.6 \\
360 \\
100\end{array}$ & $\begin{array}{l}460 \\
680 \\
721\end{array}$ & $\begin{array}{l}2,530 \\
\text { 2.580 } \\
\text { s.100 }\end{array}$ \\
\hline $\begin{array}{l}58 \\
59 \\
59\end{array}$ & $\begin{array}{l}54 \\
53\end{array}$ & 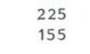 & 7 & $\begin{array}{c}1,060 \\
{ }_{335}\end{array}$ \\
\hline $\begin{array}{l}62 \\
63\end{array}$ & $\begin{array}{c}64 \\
1 \\
1\end{array}$ & $\begin{array}{l}2880 \\
807 \\
807\end{array}$ & $\begin{array}{l}645 \\
807\end{array}$ & $\begin{array}{l}1,120 \\
\text { 1.1207 } \\
807\end{array}$ \\
\hline
\end{tabular}

Table 9.2-2 Dissolved solids, residue

\begin{tabular}{|c|c|c|c|c|}
\hline $\begin{array}{c}\text { Map } \\
\text { sate } \\
\text { number } \\
\text { number }\end{array}$ & $\begin{array}{c}\text { Number of } \\
\text { observations }\end{array}$ & \multicolumn{3}{|c|}{ Dissolved solids (mg/t/s) } \\
\hline & & ${ }_{238}$ & 349 & ${ }_{447}$ \\
\hline $\begin{array}{c}2 \\
10 \\
10 \\
11\end{array}$ & & $\begin{array}{l}251 \\
2545 \\
2857 \\
287\end{array}$ & $\begin{array}{l}-451 \\
2515 \\
2485\end{array}$ & $\begin{array}{l}451 \\
245 \\
2857 \\
287\end{array}$ \\
\hline 徒 & $i$ & $\overline{392}$ & 392 & $\overline{392}$ \\
\hline $\begin{array}{l}14 \\
15 \\
17\end{array}$ & $\frac{1}{3}$ & $\begin{array}{l}411 \\
419 \\
293\end{array}$ & 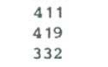 & $\begin{array}{l}411 \\
419 \\
398\end{array}$ \\
\hline$\underset{\substack{19 \\
20}}{20} \mathrm{Cl}-2$ & 4 & ${ }^{264}$ & $\begin{array}{l}312 \\
130 \\
130\end{array}$ & $\begin{array}{c}394 \\
259 \\
259\end{array}$ \\
\hline $\begin{array}{l}21 \\
22 \\
23 \\
23\end{array}$ & ${ }_{4}^{2}$ & $\begin{array}{l}578 \\
315 \\
280\end{array}$ & $\begin{array}{l}578 \\
377 \\
370\end{array}$ & $\begin{array}{l}578 \\
340 \\
4320 \\
432\end{array}$ \\
\hline${ }_{25}^{24}$ & $1^{3}$ & 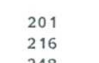 & 崩16 & $\begin{array}{c}537 \\
216 \\
216\end{array}$ \\
\hline $\begin{array}{l}26 \\
27 \\
28\end{array}$ & 1 & 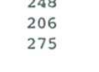 & $\begin{array}{l}3196 \\
2765 \\
275\end{array}$ & $\begin{array}{l}\text { 292 } \\
206 \\
275\end{array}$ \\
\hline 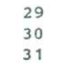 & $\frac{1}{4}$ & 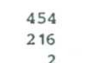 & $\begin{array}{c}454 \\
309 \\
309\end{array}$ & 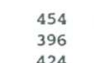 \\
\hline $\begin{array}{l}31 \\
34 \\
35\end{array}$ & ${ }_{1}^{2}$ & $\begin{array}{r}2 \\
2 \\
261\end{array}$ & $\begin{array}{l}213 \\
146 \\
261\end{array}$ & $\begin{array}{l}\text { 年240 } \\
2901 \\
261\end{array}$ \\
\hline $\begin{array}{c}36 \\
38 \\
38\end{array}$ & $3^{3}-1$ & 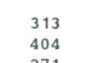 & $\substack{346 \\
454}_{450}$ & $\begin{array}{l}407 \\
532\end{array}$ \\
\hline $\begin{array}{l}40 \\
41 \\
43\end{array}$ & $\begin{array}{l}2 \\
2 \\
2\end{array}$ & 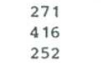 & 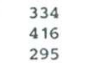 & $\begin{array}{l}396 \\
346 \\
3138\end{array}$ \\
\hline $\begin{array}{l}45 \\
46 \\
46 \\
40\end{array}$ & $\begin{array}{c}123 \\
23 \\
21\end{array}$ & $\begin{array}{c}88 \\
376 \\
376\end{array}$ & $\begin{array}{c}325 \\
542 \\
54\end{array}$ & $\begin{array}{l}2,050 \\
708\end{array}$ \\
\hline 49 & $\begin{array}{c}11 \\
3 \\
1\end{array}$ & $\begin{array}{l}600 \\
392 \\
371\end{array}$ & $\begin{array}{l}559 \\
442 \\
371\end{array}$ & $\begin{array}{r}3.260 \\
527 \\
377\end{array}$ \\
\hline $\begin{array}{c}62 \\
63 \\
63\end{array}$ & ${ }_{1}^{53}$ & $457^{0}$ & $\begin{array}{l}376 \\
457\end{array}$ & $\begin{array}{l}565 \\
457 \\
457\end{array}$ \\
\hline
\end{tabular}




\title{
9.0 SURFACE-WATER QUALITY--Continued \\ $9.3 \mathrm{pH}$
}

\section{Values for $\mathrm{pH}$ are Usually in the Near-Neutral Range}

\author{
The $\mathrm{pH}$ values of area streams indicate the presence of carbonates in rocks \\ and surficial deposits.
}

The activity of hydrogen ions involved in reactions with dissolved constituents is indicated by the $\mathrm{pH}$ of a solution. Mathematically, $\mathrm{pH}$ is defined as the negative logarithm to base 10 of the hydrogen-ion activity in moles per liter.

The $\mathrm{pH}$ values of the study area streams ranged from 6.5 to 9.5 (table 9.3-1 and figs. 9.3-1 and 9.3-2). This range is somewhat larger than the range given by Hem (1970) of 6.5 to 8.5 for "river water in areas not influenced by pollution." A pH of 6.9 or less was observed in more than one sample at only 6 of 37 sites. Waters from most streams in the study area have $\mathrm{pH}$ values higher than 7.0 (neutral) and are therefore considered basic. The presence of carbon- ate rock throughout the area probably is responsible for the above-neutral $\mathrm{pH}$ values although the higher values also could be a result of photosynthesis.

The recommended range for the $\mathrm{pH}$ of domestic water supplies is 5.0 to 9.0 (U.S. Environmental Protection Agency, 1976, p. 178). This rather wide range is considered acceptable because $\mathrm{pH}$ is relatively easy to adjust during water treatment. $\mathrm{A} \mathrm{pH}$ within the range of 6.5 to 9.0 is recommended to provide adequate protection for survival of freshwater aquatic life. Outside of this range, aquatic animal life may suffer adverse physiological effects. 


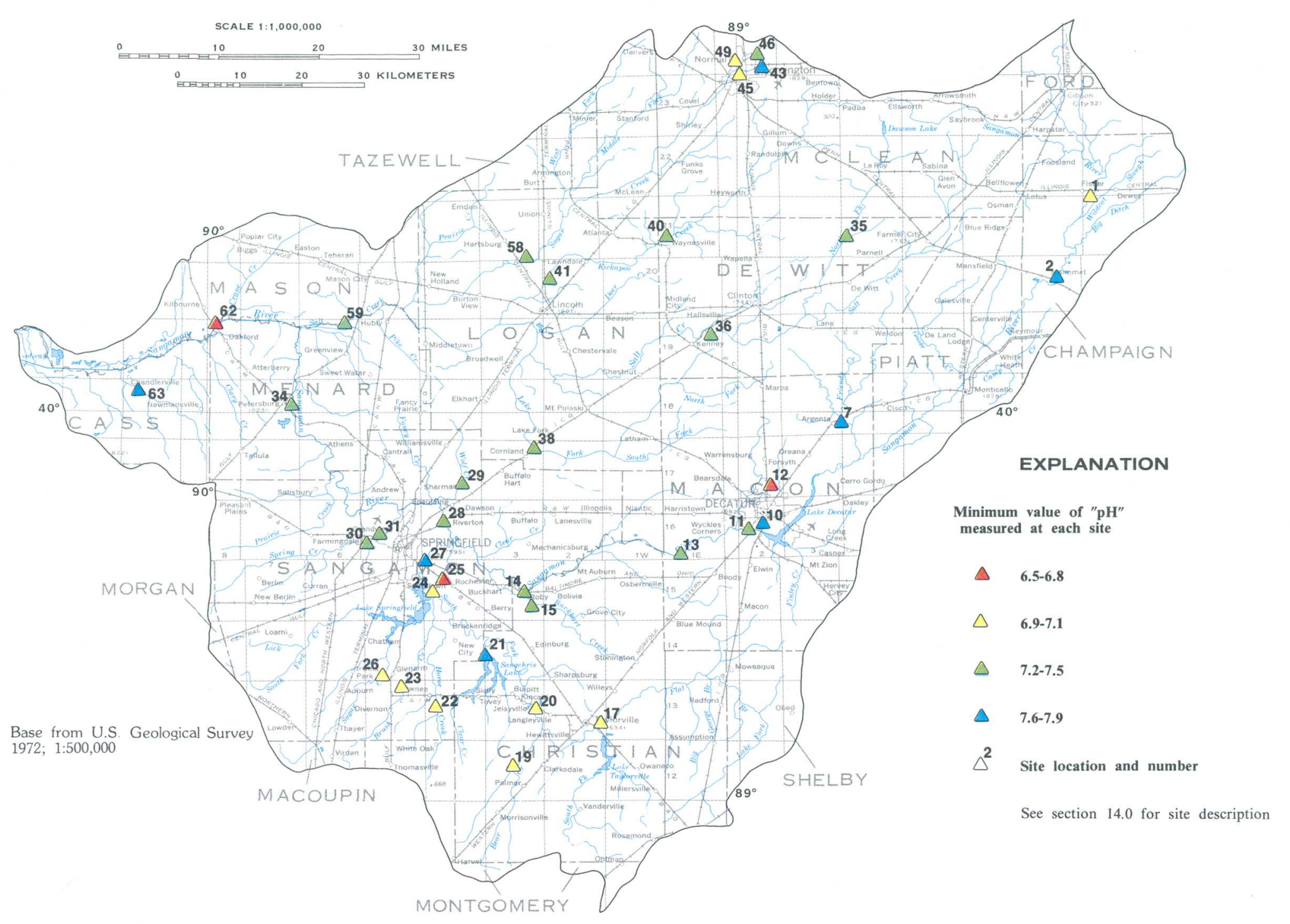

Table 9.3-1 Maximum and minimum $\mathrm{pH}$ values measured in the area.

\begin{tabular}{|c|c|c|c|}
\hline \multirow{2}{*}{$\begin{array}{c}\text { Map } \\
\text { site } \\
\text { number }\end{array}$} & \multirow{2}{*}{$\begin{array}{l}\text { Number of } \\
\text { observations }\end{array}$} & \multicolumn{2}{|c|}{$\mathrm{pH}$ values } \\
\hline & & Minimum & Maximum \\
\hline 1 & 31 & 6.9 & 8.5 \\
\hline 2 & 11 & 7.8 & 8.5 \\
\hline 7 & 1 & 7.6 & \\
\hline 10 & 27 & 7.8 & 8.8 \\
\hline 11 & 53 & & 8.6 \\
\hline 12 & 32 & 6.5 & 7.7 \\
\hline 13 & 66 & 7.4 & 8.5 \\
\hline 14 & 55 & 7.2 & 8.9 \\
\hline 15 & 1 & 7.3 & \\
\hline 17 & 36 & 7.0 & 8.5 \\
\hline 19 & 6 & 7.0 & 7.6 \\
\hline 20 & 52 & 6.9 & 8.1 \\
\hline 21 & 27 & 7.6 & 8.4 \\
\hline 22 & 2 & 6.9 & 7.3 \\
\hline 23 & 4 & 7.1 & 8.0 \\
\hline 24 & 6 & 7.0 & 8.3 \\
\hline 25 & 46 & 6.8 & 8.7 \\
\hline 26 & $\begin{array}{r}7 \\
33\end{array}$ & $\begin{array}{l}7.0 \\
7.6\end{array}$ & 8.3 \\
\hline $\begin{array}{l}27 \\
28\end{array}$ & $\begin{array}{l}33 \\
47 \\
47\end{array}$ & 7.6 & 8.6 \\
\hline 28 & 47 & 7.3 & 8.5 \\
\hline 29 & 1 & 7.4 & 7.4 \\
\hline 30 & 6 & 7.5 & 7.8 \\
\hline 31 & 32 & 7.2 & 8.3 \\
\hline 34 & 51 & 7.2 & 9.0 \\
\hline 35 & 1 & 7.2 & 7.2 \\
\hline 36 & 45 & 7.3 & 8.8 \\
\hline 38 & 53 & 7.3 & 8.7 \\
\hline 40 & 43 & 7.2 & 8.6 \\
\hline 41 & 41 & 7.3 & 8.6 \\
\hline 43 & 2 & 7.9 & 8.4 \\
\hline 45 & 187 & 7.0 & 8.6 \\
\hline 46 & 2 & 7.7 & 9.4 \\
\hline 49 & 167 & 7.0 & 9.5 \\
\hline 58 & 53 & 7.5 & 8.7 \\
\hline 59 & 50 & 7.5 & 8.6 \\
\hline 62 & 60 & 6.5 & 9.1 \\
\hline 63 & 1 & 7.8 & 7.8 \\
\hline
\end{tabular}

Figure 9.3-1 Minimum values of $\mathrm{pH}$ measured at water-quality sites.

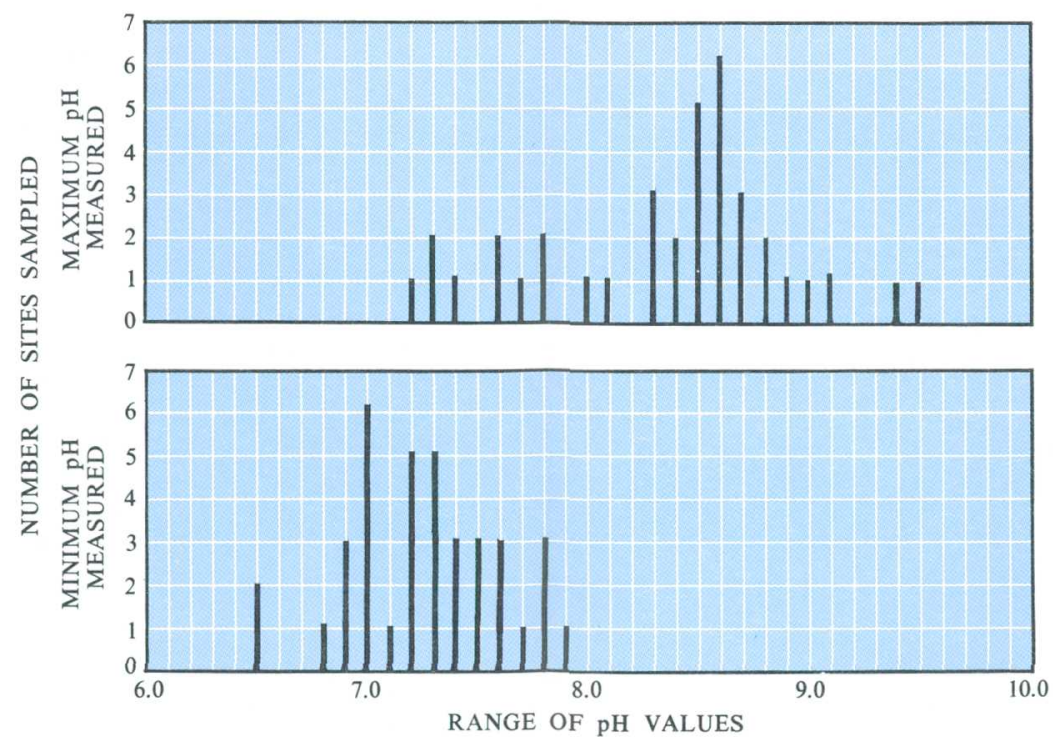
Figure 9.3-2 Range and distribution of maximum and
minimum values of $\mathrm{pH}$ at water-quality sites. 


\subsection{SURFACE-WATER QUALITY--Continued 9.4 Iron}

\section{Concentrations of Iron Vary Widely}

\section{Iron, an element essential to plants and animals, is commonly associated with coal in the Pennsylvanian System.}

Iron is a common constituent of the surface and ground waters of the study area. It is commonly associated with coal of the Pennsylvanian System in the ferrous form $\left(\mathrm{Fe}^{+2}\right)$. This soluble form of iron is easily changed to the relatively insoluble ferric form $\left(\mathrm{Fe}^{+3}\right)$ when it enters an oxidizing system (exposure to air). The dissolution of iron is dependent upon, and inversely related to, $\mathrm{pH}$. Therefore, in streams it can occur as dissolved iron (in solution), precipitated iron (found in bed material), or suspended iron (moving in suspension). Total recoverable iron in this report refers to the dissolved plus the suspended concentrations. Surface mining can increase the amount of iron available to waters downstream by exposing more iron-bearing minerals to weathering.

The average concentrations of total recoverable iron at sites in the area ranged from 441 to 9,700 micrograms per liter $(\mu \mathrm{g} / \mathrm{L})($ table 9.4-1). The average total recoverable iron concentrations at area sites are shown by ranges in figure 9.4-1.

Average dissolved iron concentrations at area sites ranged from 6 to $1,380 \mu \mathrm{g} / \mathrm{L}$ (table 9.4-2). The average dissolved iron concentrations at area sites are shown by ranges in figure 9.4-2.

The range and distribution of the average values of total and dissolved iron concentrations for sites in the area are shown in figure 9.4-3. The average concentration based on all sampling sites is $126 \mu \mathrm{g} / \mathrm{L}$ for dissolved iron and $2,410 \mu \mathrm{g} / \mathrm{L}$ for total recoverable iron.

Concentrations of dissolved iron in surface waters seldom reach 1,000 $\mu \mathrm{g} / \mathrm{L}$ (American Public Health Association, 1976, p. 207). Concentrations were generally below this level in the study area. However, four sites had maximum concentrations that exceeded the $1,000 \mu \mathrm{g} / \mathrm{L}$ level.

Iron is an essential element to plants and animals. It is vital to the oxygen transport mechanism in the blood of all vertebrate animals, and its absence in plants can be a limiting growth factor. However, a maximum limit of $300 \mu \mathrm{g} / \mathrm{L}$ has been recommended by the U.S. Environmental Protection Agency (1976, p. 79) to prevent staining and objectionable tastes in domestic water supplies. The limit for iron is based on aesthetic rather than toxicological considerations. Total recoverable concentrations of iron commonly exceeded $300 \mu \mathrm{g} / \mathrm{L}$, whereas only two sites had average concentrations of dissolved iron in excess of the recommended limit. 




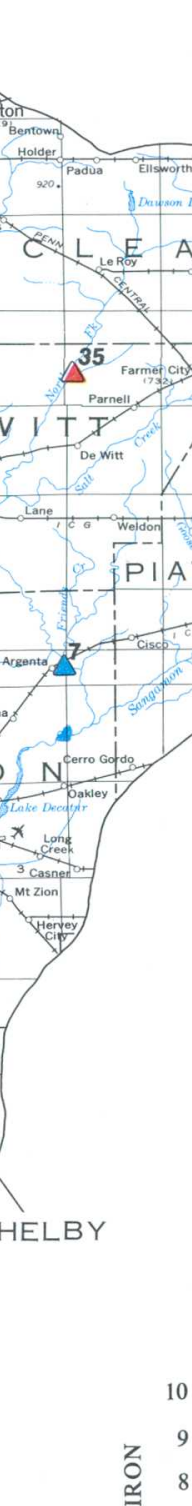

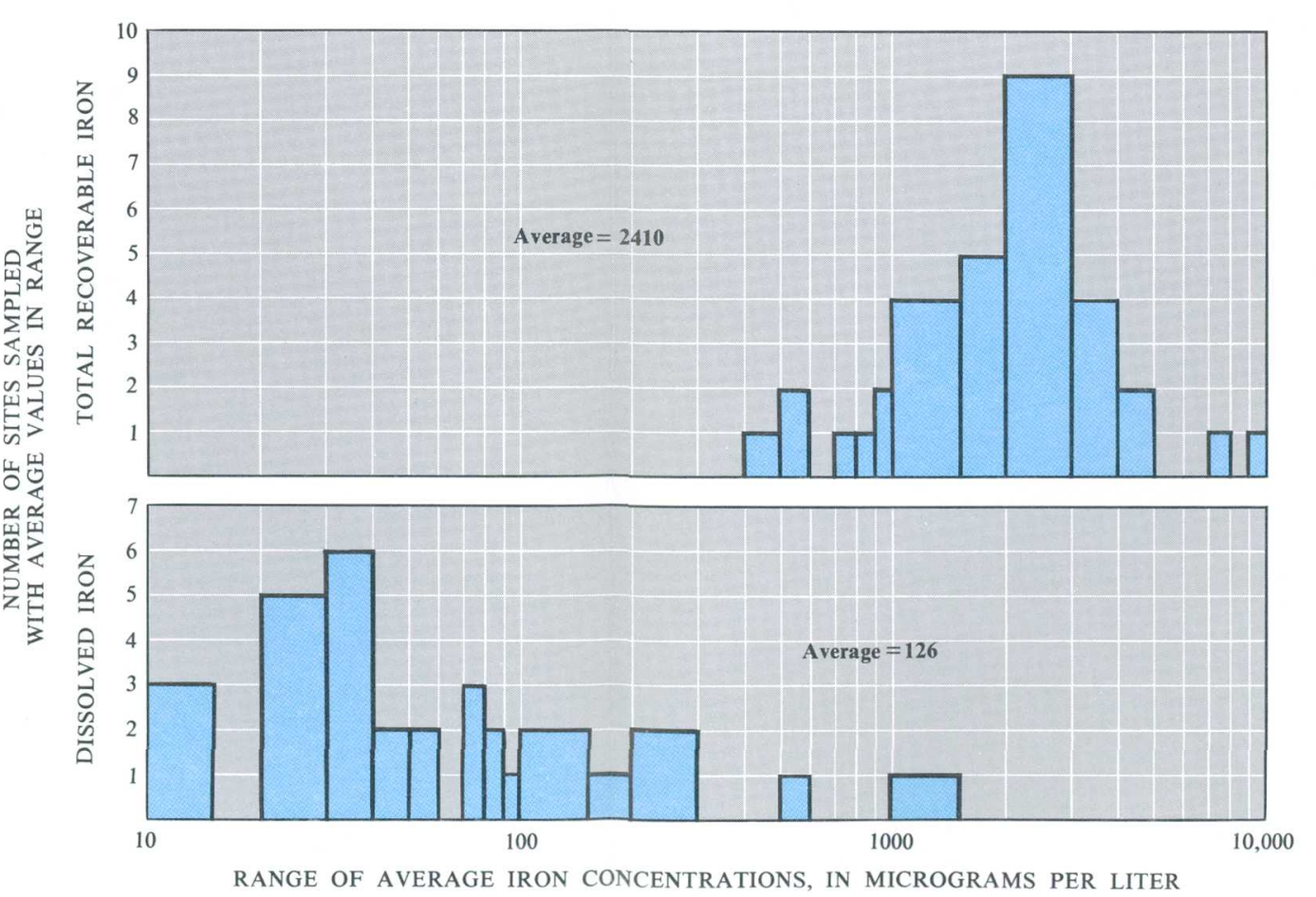

RANGE OF AVERAGE IRON CONCENTRATIONS, IN MICROGRAMS PER LITER

Figure 9.4-3 Range and distribution of average values of total recoverable
EXPLANATION Average concentration of total
recoererabe irro at each site,
in mierogorams per liter

$\triangle$ Less than 1000

$\triangle \quad 1000-2000$

$\triangle \quad 2001-3000$

$\Delta \quad$ Greater than 3000

$\triangle^{8} \quad$ Site location and number

See section 14.0 for site descriptio and dissolved iron concentrations measured at water-quality sites.
TAEWELL

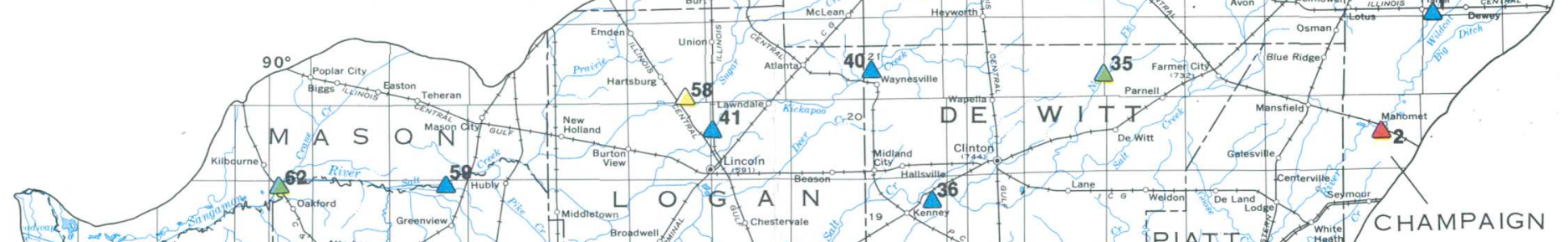

M.m.

CAS S

EXPLANATION

Average concentration of
dissolved iron at each site,

$\Delta \quad$ Less than 40

$\triangle \quad 41-100$

$\triangle \quad$ Greater than 100

$\triangle$ unsampled sites

$\triangle^{8} \quad$ Site location and number See section 14.0 for site
description ints

Figure 9.4-2 Average values of dissolved iron at water-quality sites.

\begin{tabular}{|c|c|c|c|c|}
\hline 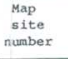 & 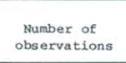 & $\begin{array}{l}\text { Iron, } \\
\text { Minninum }\end{array}$ & 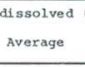 & 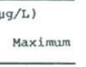 \\
\hline 10 & & 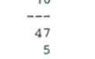 & 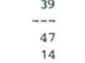 & $\begin{array}{l}98 \\
-97 \\
24\end{array}$ \\
\hline 13 & $\stackrel{0}{2}$ & 16 & 23 & 30 \\
\hline $\begin{array}{l}18 \\
17 \\
17\end{array}$ & 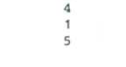 & 党 & $\begin{array}{l}58 \\
80 \\
86\end{array}$ & 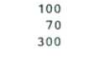 \\
\hline $\begin{array}{l}19 \\
201 \\
21 \\
21\end{array}$ & : & 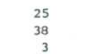 & 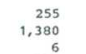 & 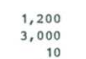 \\
\hline $\begin{array}{l}22 \\
23 \\
23\end{array}$ & $\frac{2}{4}$ & $\begin{array}{c}63 \\
65 \\
37\end{array}$ & $\begin{array}{r}266 \\
242 \\
111\end{array}$ & 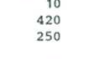 \\
\hline 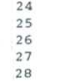 & & $\begin{array}{c}20 \\
\text { 20 } \\
30 \\
5 \\
5\end{array}$ & $\begin{array}{l}198 \\
1,16 \\
1,16\end{array}$ & $\begin{array}{l}530 \\
230 \\
\text { 230 } \\
700\end{array}$ \\
\hline $\begin{array}{l}290 \\
30 \\
31\end{array}$ & & 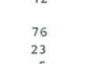 & 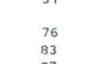 & $\frac{176}{170}$ \\
\hline 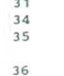 & 2 & $\begin{array}{c}5 \\
\text { so } \\
\text { s. }\end{array}$ & 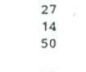 & 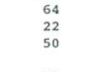 \\
\hline 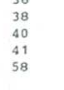 & ${ }_{3}^{6}$ & $\begin{array}{l}5 \\
5 \\
5 \\
5\end{array}$ & 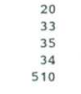 & 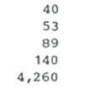 \\
\hline 步 & 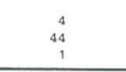 & 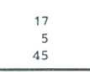 & 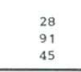 & $\begin{array}{c}50 \\
1,800 \\
450 \\
45\end{array}$ \\
\hline
\end{tabular}

9.0 SURFACE-WATER QUALITY--Continued 


\title{
9.0 SURFACE-WATER QUALITY-Continued \\ 9.5 Manganese
}

\section{Concentrations of Manganese Often Exceed Recommended Limits}

\author{
Measured concentrations of manganese were commonly in excess of the \\ U.S. Environmental Protection Agency recommended limit for domestic water supply.
}

Manganese is an element widely distributed in igneous rocks and soils, but its total abundance in the Earth's crust is small enough to consider it a minor element. Manganese and iron are chemically similar. However, because manganese has a lower affinity for oxygen, it stays in solution longer than does iron (Rankama and Sahama, 1950).

Average concentrations of total recoverable and dissolved manganese for each of 33 water-quality sites are shown in figures 9.5-1 and 9.5-2, respectively. Average concentrations of total recoverable manganese at area sites ranged from 40 to 814 micrograms per liter $(\mu \mathrm{g} / \mathrm{L})$ with the average for all sites being $280 \mu \mathrm{g} / \mathrm{L}$ (table $9.5-1$ and fig. 9.5-3). Average dissolved manganese con- centrations in the area ranged from 5 to $710 \mu \mathrm{g} / \mathrm{L}$, with the average for all sites being $180 \mu \mathrm{g} / \mathrm{L}$ (table 9.5-2 and fig. 9.5-3).

Manganese is both vital for plants and animals (U.S. Environmental Protection Agency, 1976, p. 95). Inadequite amounts can inhibit plant growth or adversely affect animal reproduction. A maximum allowable concentration of less than 50 $\mu \mathrm{g} / \mathrm{L}$ is recommended for domestic water supplies to prevent staining of laundry and objectionable tastes (U.S. Environmental Protection Agency, 1976, p. 96). Average concentrations of both total recoverable and dissolved manganese in the study area commonly exceeded $50 \mu \mathrm{g} / \mathrm{L}$. 

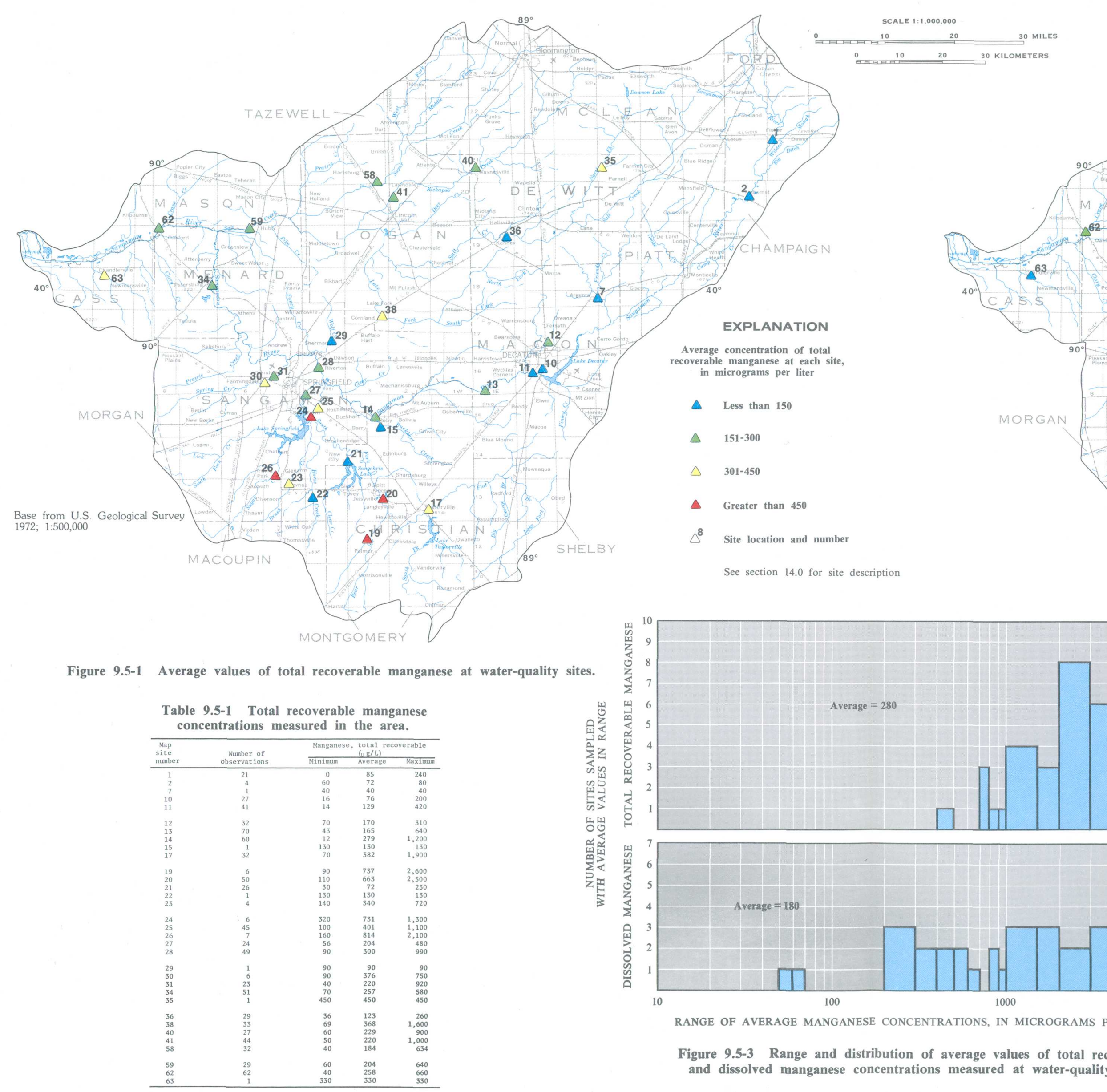

Average concentration of

Average concentration of total
recoverable manganese at each sit,
in microgans per

Less than 150

$\triangle \quad 151-300$

$\triangle \quad 301-450$

$\triangle \quad$ Greater than 450

$\triangle \quad$ Site location and number

See section 14.0 for site descriptio

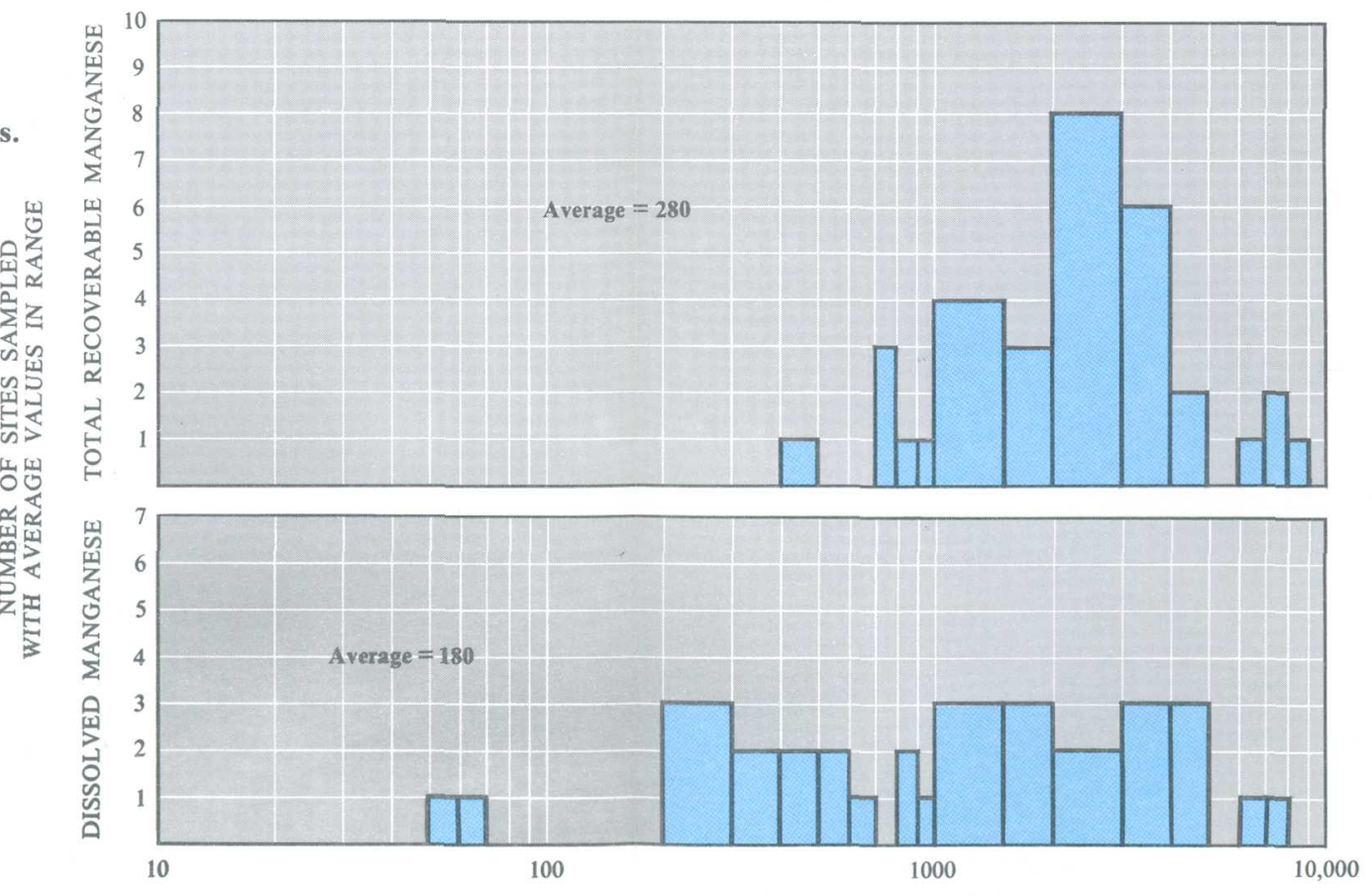

Figure 9.5-2 Average values of dissolved manganese at water-quality sites.

RANGE OF AVERAGE MANGANESE CONCENTRATIONS, MNGROGRAMS PER LITER Figure 9.5-3 Range and distribution of average values of total recoverable
and dissolved manganese concentrations measured at water-quality sites.

\begin{tabular}{|c|c|c|c|c|}
\hline Nap & & Mangan & dis soll & $(\mu \mathrm{g} / \mathrm{t})$ \\
\hline$\frac{\text { siter }}{\text { number }}$ & 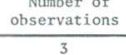 & $\frac{\frac{\text { Mininum }}{17}}{17}$ & $\begin{array}{ll}\text { Average } \\
\\
46\end{array}$ & \begin{tabular}{|l|} 
Maximu \\
70
\end{tabular} \\
\hline $\begin{array}{l}10 \\
11\end{array}$ & 3 & $\begin{array}{l}25 \\
5 \\
5\end{array}$ & 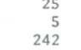 & $\begin{array}{c}25 \\
\text { at } \\
410\end{array}$ \\
\hline 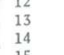 & $\frac{2}{2}$ & ${ }_{5}^{5}$ & $\begin{array}{l}\substack{128 \\
311} \\
311\end{array}$ & $\begin{array}{l}250 \\
600 \\
600\end{array}$ \\
\hline $\begin{array}{l}17 \\
19\end{array}$ & & $\begin{array}{l}24 \\
5.5 \\
5.5\end{array}$ & $\begin{array}{l}321 \\
710 \\
710\end{array}$ & $\begin{array}{l}980 \\
2600 \\
2000\end{array}$ \\
\hline $\begin{array}{l}\frac{21}{22} \\
25 \\
25\end{array}$ & $\frac{4}{1}$ & 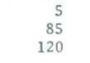 & $\begin{array}{c}86 \\
\text { sos } \\
305\end{array}$ & 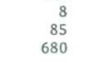 \\
\hline $\begin{array}{l}24 \\
25 \\
25\end{array}$ & 6 & $\begin{array}{c}50 \\
30 \\
40 \\
40\end{array}$ & 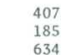 & $\begin{array}{l}1,300 \\
\text { 1, 2000 } \\
\text {, } 100\end{array}$ \\
\hline $\begin{array}{l}27 \\
27 \\
28\end{array}$ & ${ }^{6}$ & 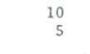 & $\begin{array}{l}116 \\
488 \\
488\end{array}$ & $\begin{array}{l}450 \\
970 \\
970\end{array}$ \\
\hline $\begin{array}{l}29 \\
330 \\
31\end{array}$ & 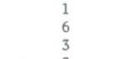 & $\begin{array}{l}57 \\
57 \\
57 \\
57\end{array}$ & $\begin{array}{c}57 \\
203 \\
84 \\
83\end{array}$ & 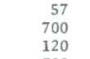 \\
\hline 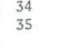 & ${ }_{1}^{t}$ & ${ }_{35}^{5}$ & 年 & $\begin{array}{l}300 \\
300\end{array}$ \\
\hline $\begin{array}{l}38 \\
\text { sit } \\
41 \\
41\end{array}$ & $\begin{array}{l}3 \\
3 \\
6 \\
6\end{array}$ & $\begin{array}{r}26 \\
10 \\
10 \\
10\end{array}$ & $\begin{array}{l}187 \\
167 \\
596 \\
59\end{array}$ & $\begin{array}{l}620 \\
\text { s. } \\
170\end{array}$ \\
\hline $\begin{array}{l}59 \\
62 \\
65 \\
6.5\end{array}$ & 4 & 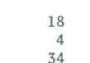 & 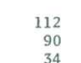 & $\begin{array}{c}230 \\
630 \\
630\end{array}$ \\
\hline
\end{tabular}




\subsection{SURFACE-WATER QUALITY--Continued \\ 9.6 Sulfate}

\section{Sulfate Concentrations are Low to Moderate}

\section{Measured concentrations of sulfate seldom exceed the criterion established by the U.S. Environmental Protection Agency.}

Metallic sulfides, mainly pyrite $\left(\mathrm{FeS}_{2}\right)$ and marcasite $\left(\mathrm{FeS}_{2}\right)$, are oxidized to yield sulfate ions. Both pyrite and marcasite are present in coal beds that underlie almost the entire study area. Crystals of pyrite are also commonly found in black shale and bituminous sandstones (Krauskopf, 1967). Sulfate in water can be used as an indicator of acid mine drainage in mined areas (Toler, 1982). The measured concentrations of sulfate in Area 28 ranged from 6 to 270 milligrams per liter $(\mathrm{mg} / \mathrm{L})$ with an average of 64 $\mathrm{mg} / \mathrm{L}$ for all sites. The areal distribution of average sulfate concentrations among sites is shown in figure 9.6-1. The average sulfate concentrations ranged from 27 to $170 \mathrm{mg} / \mathrm{L}$ (table 9.6-1 and fig. 9.6-2).

Concentrations of sulfate in excess of $250 \mathrm{mg} / \mathrm{L}$ can cause physiological problems, undesirable tastes, and can raise the costs of water treatment (U.S. Environmental Protection Agency, 1976, p. 205). None of the water-quality-sampling sites had average sulfate concentrations in excess of this limit. 


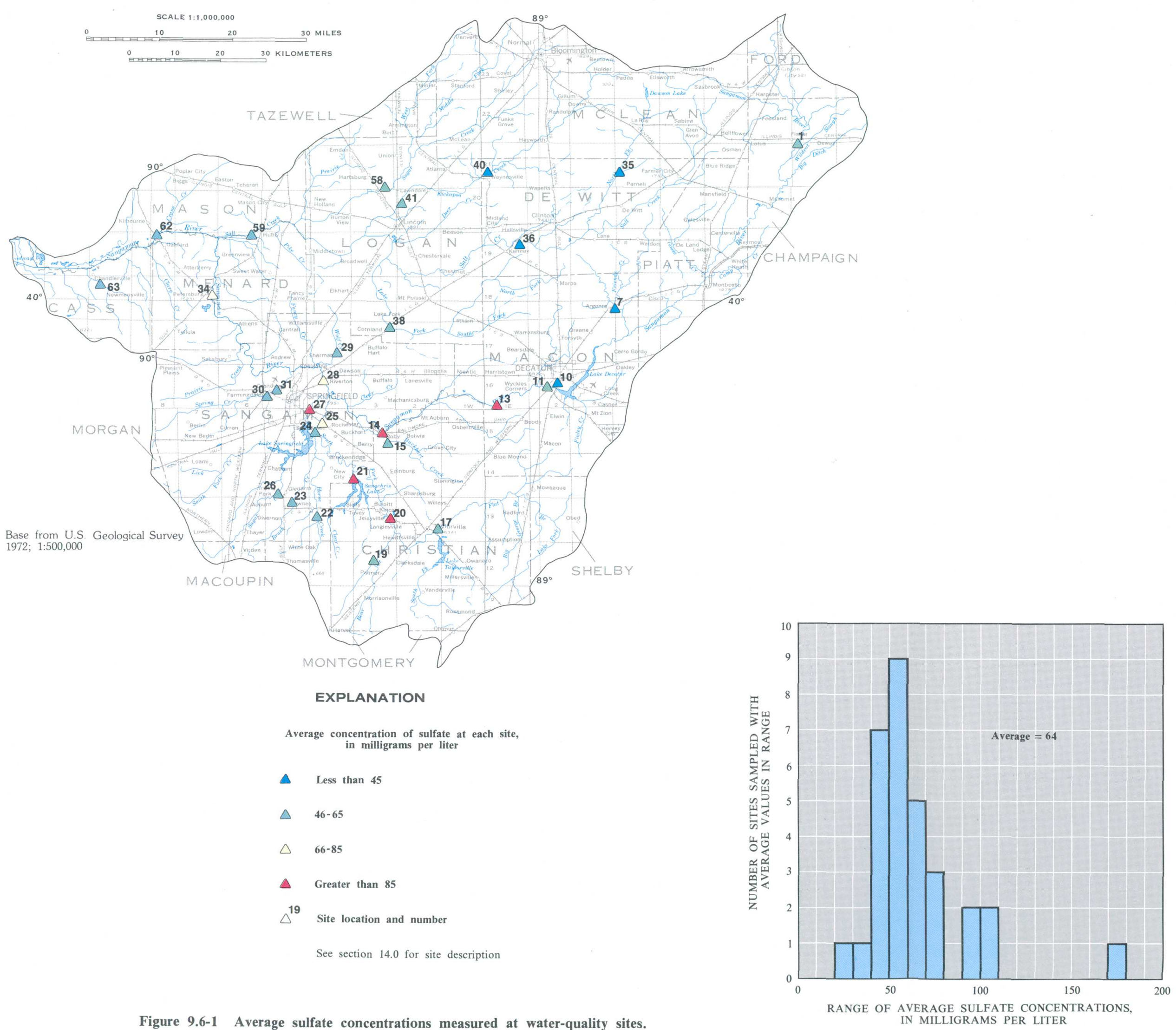

Table 9.6-1 Sulfate concentrations measured in the area.

\begin{tabular}{|c|c|c|c|c|}
\hline \multirow{2}{*}{$\begin{array}{l}\text { Map } \\
\text { site } \\
\text { number }\end{array}$} & \multirow{2}{*}{$\begin{array}{c}\text { Number of } \\
\text { observations }\end{array}$} & \multicolumn{2}{|c|}{ Sulfate concentration } & \multirow{2}{*}{$\frac{(\mathrm{mg} / \mathrm{L})}{\text { Maximun }}$} \\
\hline & & Minimum & Average & \\
\hline 1 & 3 & 27 & 60 & 110 \\
\hline${ }_{7}^{2}$ & $\begin{array}{l}0 \\
1\end{array}$ & 44 & $\overline{44}$ & -74 \\
\hline $\begin{array}{l}10 \\
11\end{array}$ & $\begin{array}{l}29 \\
56\end{array}$ & $\begin{array}{l}29 \\
25\end{array}$ & $\begin{array}{l}44 \\
55\end{array}$ & $\begin{array}{r}70 \\
120\end{array}$ \\
\hline 12 & & $\ldots$ & & \\
\hline $\begin{array}{l}12 \\
13\end{array}$ & 70 & 28 & $\overline{97}$ & $\overline{260}$ \\
\hline 14 & 60 & 30 & 100 & 270 \\
\hline $\begin{array}{l}15 \\
17\end{array}$ & $\frac{1}{36}$ & $\begin{array}{l}48 \\
24\end{array}$ & $\begin{array}{l}48 \\
46\end{array}$ & $\begin{array}{l}48 \\
74\end{array}$ \\
\hline 19 & 6 & 42 & & \\
\hline 20 & 50 & & 109 & $\begin{array}{l}27 \\
270\end{array}$ \\
\hline 21 & 1 & 170 & 170 & 170 \\
\hline $\begin{array}{l}22 \\
23\end{array}$ & $\frac{2}{4}$ & $\begin{array}{l}21 \\
54\end{array}$ & $\begin{array}{l}58 \\
65\end{array}$ & $\begin{array}{l}94 \\
75\end{array}$ \\
\hline 23 & & & 65 & 75 \\
\hline $\begin{array}{l}24 \\
25\end{array}$ & 5 & 26 & 60 & 99 \\
\hline $\begin{array}{l}25 \\
26\end{array}$ & $\begin{array}{r}46 \\
7\end{array}$ & ${ }_{11}^{27}$ & $\begin{array}{l}76 \\
56\end{array}$ & $\begin{array}{r}190 \\
79\end{array}$ \\
\hline 27 & 34 & 32 & $\begin{array}{l}56 \\
93\end{array}$ & 170 \\
\hline 28 & 50 & 6 & 78 & 180 \\
\hline 29 & 1 & 56 & 56 & 56 \\
\hline $\begin{array}{l}30 \\
31\end{array}$ & $\begin{array}{c}6 \\
33\end{array}$ & ${ }_{23}^{29}$ & $\begin{array}{l}50 \\
54\end{array}$ & $\begin{array}{l}81 \\
86\end{array}$ \\
\hline 34 & $\begin{array}{l}33 \\
51\end{array}$ & ${ }_{36}^{23}$ & $\begin{array}{l}54 \\
79\end{array}$ & $\begin{array}{r}86 \\
160\end{array}$ \\
\hline 35 & 1 & 27 & 27 & 27 \\
\hline 36 & 6 & 31 & 41 & 48 \\
\hline $\begin{array}{l}38 \\
40\end{array}$ & 3 & 51 & 54 & 57 \\
\hline & 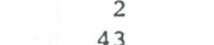 & 32 & & $\begin{array}{l}44 \\
65\end{array}$ \\
\hline $\begin{array}{l}41 \\
58\end{array}$ & $\begin{array}{l}43 \\
54\end{array}$ & $\begin{array}{l}35 \\
34\end{array}$ & 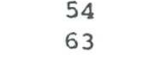 & $\begin{array}{l}65 \\
86\end{array}$ \\
\hline 59 & 4 & 42 & 50 & 58 \\
\hline $\begin{array}{l}62 \\
63 \\
63\end{array}$ & $\begin{array}{r}61 \\
1\end{array}$ & $\begin{array}{l}29 \\
46\end{array}$ & $\begin{array}{l}60 \\
46\end{array}$ & $\begin{array}{r}140 \\
46\end{array}$ \\
\hline
\end{tabular}

Figure 9.6-2 Range and distribution of average values of sulfate measured at water-quality sites in the study area.
in 


\subsection{SURFACE-WATER QUALITY--Continued \\ 9.7 Alkalinity}

\section{Alkalinity Concentrations Vary Widely}

\section{Alkalinity concentrations generally are large enough to buffer small acid inflows.}

\begin{abstract}
Alkalinity, the capacity of a solution to neutralize acid, can be caused by a variety of different solute species. In most natural waters, the alkalinity is produced mainly by carbonate and bicarbonate ions. Because differences occur in the proportions of constituents contributing to alkalinity, its concentrations are commonly reported as an equivalent amount of calcium carbonate $\left(\mathrm{CaCO}_{3}\right)$ in milligrams per liter (mg/L).
\end{abstract}

Measurements of alkalinity in 577 samples from Area 28 streams ranged from 9 to $385 \mathrm{mg} / \mathrm{L}$ as $\mathrm{CaCO}_{3}$. The areal variation in average alkalinity concentrations at sites in the study area is shown in figure 9.7-1. The average alkalinity concentrations ranged from 90 to $280 \mathrm{mg} / \mathrm{L}$ as $\mathrm{CaCO}_{3}$, with an average value of $182 \mathrm{mg} / \mathrm{L}$ as $\mathrm{CaCO}_{3}$ for all of the sites (table 9.7-1 and fig. 9.7-2).

Alkalinity values of $20 \mathrm{mg} / \mathrm{L}$ as $\mathrm{CaCO}_{3}$ or more are generally recommended for freshwater aquatic life. Values less than this leave the water susceptible to rapid changes in $\mathrm{pH}$. Components of alkalinity, such as carbonate and bicarbonate, can chemically combine with toxic heavy metals and reduce their toxicity markedly (U.S. Environmental Protection Agency, 1976, p. 7). Streams within the study area generally had alkalinities capable of maintaining a sufficient buffering capacity against small volumes of acid inflow. 


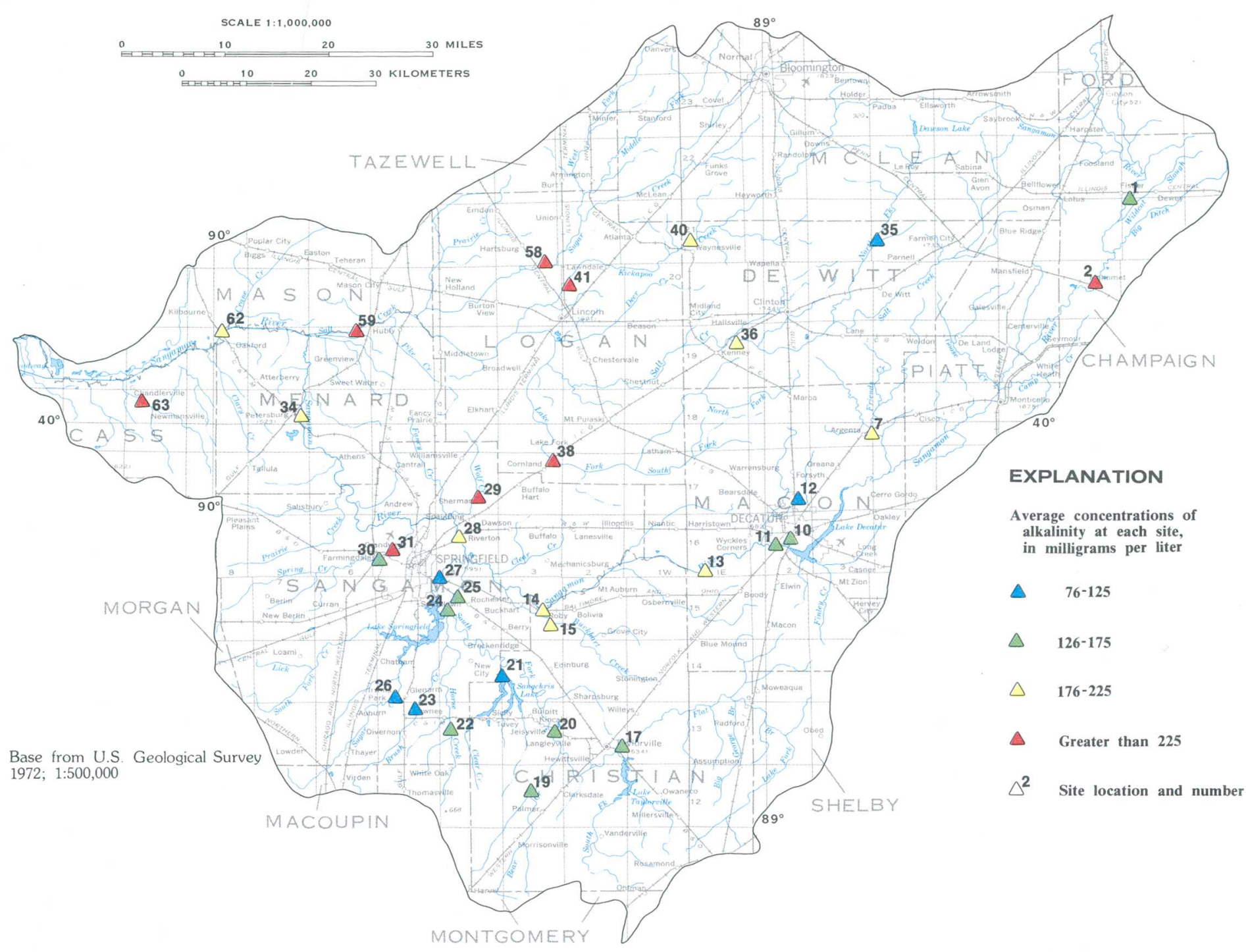

Figure 9.7-1 Average values of alkalinity measured at water-quality sites.

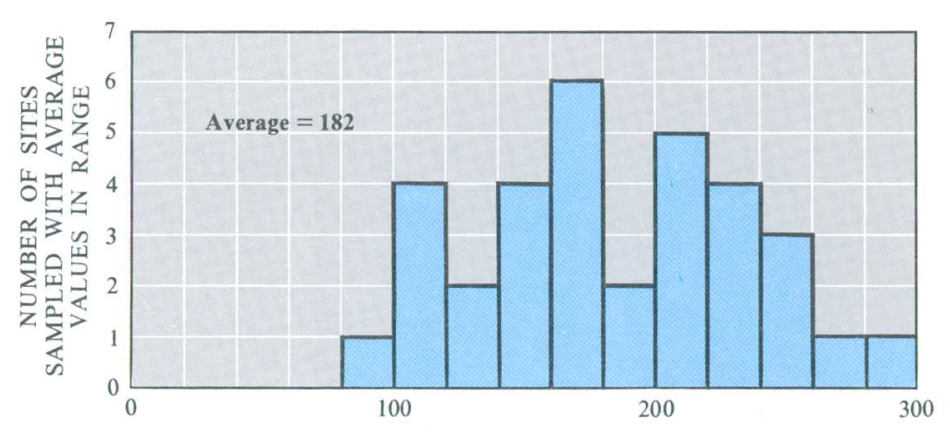

RANGE OF AVERAGE ALKALINITY CONCENTRATION,
IN MILLIGRAMS PER LITER

Figure 9.7-2 Range and distribution of average values of alkalinity measured at water-quality sites
in the study area.

Table 9.7-1 Alkalinity concentrations measured in the area.

\begin{tabular}{|c|c|c|c|c|}
\hline \multirow{2}{*}{$\begin{array}{c}\text { Map } \\
\text { site } \\
\text { number }\end{array}$} & \multirow{2}{*}{$\begin{array}{l}\text { Number of } \\
\text { observations }\end{array}$} & \multicolumn{3}{|c|}{ Alkalinity as $\mathrm{CaCO}_{3}(\mathrm{mg} / \mathrm{L})$} \\
\hline & & Minimum & Average & Maximum \\
\hline 1 & 3 & 81 & 175 & 240 \\
\hline 2 & 4 & 205 & 232 & 262 \\
\hline 7 & 1 & 220 & 220 & 220 \\
\hline 10 & 4 & 143 & 164 & 190 \\
\hline 11 & 25 & 91 & 170 & 274 \\
\hline 12 & 32 & 23 & 108 & 270 \\
\hline 13 & 66 & 42 & 204 & 319 \\
\hline 14 & 58 & 50 & 210 & 298 \\
\hline 15 & 1 & 180 & 180 & 180 \\
\hline 17 & 28 & 10 & 170 & 316 \\
\hline 19 & 6 & 93 & 147 & 210 \\
\hline 20 & 53 & 9 & 136 & 285 \\
\hline 21 & 2 & 89 & 90 & 90 \\
\hline 22 & 2 & 94 & 147 & 200 \\
\hline 23 & 4 & 57 & 123 & 200 \\
\hline 24 & 5 & 67 & 143 & 210 \\
\hline 25 & 47 & 23 & 152 & 342 \\
\hline 26 & 7 & 21 & 113 & 200 \\
\hline 27 & 3 & 96 & 102 & 110 \\
\hline 28 & 46 & 65 & 176 & 284 \\
\hline 29 & 1 & 240 & 240 & 240 \\
\hline 30 & 6 & 87 & 170 & 250 \\
\hline 31 & 1 & 241 & 241 & 241 \\
\hline 34 & 51 & 52 & 188 & 385 \\
\hline 35 & 1 & 110 & 110 & 110 \\
\hline 36 & 8 & 147 & 202 & 250 \\
\hline 38 & 6 & 180 & 270 & 358 \\
\hline 40 & ${ }^{4}$ & 160 & 217 & 245 \\
\hline $\begin{array}{l}41 \\
50\end{array}$ & 38 & 102 & 230 & 363 \\
\hline 58 & 13 & 79 & 238 & 305 \\
\hline 59 & 9 & 178 & 250 & 294 \\
\hline 62 & 47 & & 212 & 298 \\
\hline 63 & 1 & 280 & 280 & 280 \\
\hline
\end{tabular}




\subsection{SURFACE-WATER QUALITY--Continued \\ 9.8 Trace Elements and Other Constituents}

\section{Concentrations of Trace Elements are Variable}

\section{Concentrations of many trace elements and other constituents are dependent on their availability and the $\mathrm{pH}$ of surface water.}

Trace elements and other constituents commonly occur in most streams. Major sources of these elements include soils, geologic strata underlying the basin, and atmospheric fallout.

Average concentrations of dissolved trace elements and other constituents in Area 28 generally are small due to the near-neutral $\mathrm{pH}$ values of streams in the study area, however, concentration ranges generally are large (table 9.8-1). At lower pH values (acidic waters), many minerals are more soluable and concentrations of trace elements are often higher.

In low concentrations, most trace elements are essential to life. However, in high concentrations, the same elements may be toxic to man, plants, or animals. Although high concentrations of trace elements can occur naturally, most high concentrations in surface waters generally are associated with industrial- waste discharge.

The recommended maximum concentrations for selected elements (U.S. Environmental Protection Agency, 1976) are: crops;

Boron, 750 micrograms per liter $(\mu \mathrm{g} / \mathrm{L})$ for field

Cadmium, $10 \mu \mathrm{g} / \mathrm{L}$ for domestic water supply, $0.4 \mu \mathrm{g} / \mathrm{L}$ for the most sensitive aquatic life;
Chloride, 250 milligrams per liter $(\mathrm{mg} / \mathrm{L})$ for domestic water supplies;

Chromium, $50 \mu \mathrm{g} / \mathrm{L}$ for domestic water supply, $100 \mu \mathrm{g} / \mathrm{L}$ for aquatic life;

Copper, $1 \mathrm{mg} / \mathrm{L}$ for domestic supply;

Nitrate, $10 \mathrm{mg} / \mathrm{L}$ nitrate nitrogen $(\mathrm{N})$ for domestic water supply;

Zinc, $5 \mathrm{mg} / \mathrm{L}$ for domestic water supplies.

Maximum measured concentrations for all the above elements, except chromium and copper, exceeded the recommended limit. However, average concentrations were well below the limits for all elements except phosphorus which is in fertilizers used extensively in the study area. High phosphorus concentrations often promote nuisance algal growth in lakes, reservoirs, and streams. To prevent these nuisances in natural waters, the U.S. Environmental Protection Agency (1976, p. 188) recommends the following maximum limits for phosphorus concentrations:

$25 \mu \mathrm{g} / \mathrm{L}$ within lakes and reservoirs;

$50 \mu \mathrm{g} / \mathrm{L}$ in any stream at the point of entry to a lake or reservoir;

$100 \mu \mathrm{g} / \mathrm{L}$ in any stream not discharging directly into a lake or reservoir. 


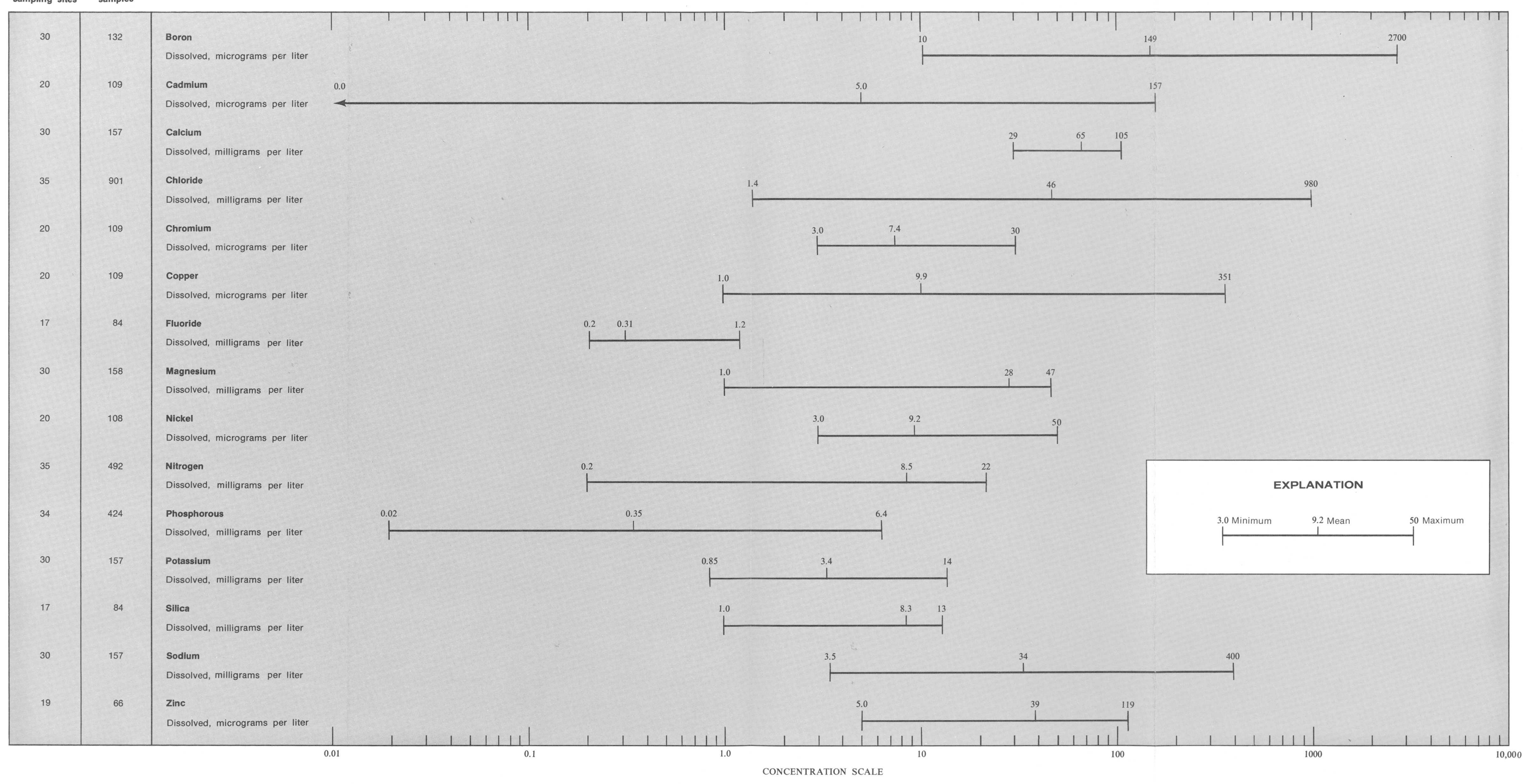

Figure 9.8-1 Range of concentrations of selected constituents measured at water-quality sites. 


\title{
9.0 SURFACE-WATER QUALITY--Continued \\ 9.9 Suspended Sediment
}

\section{Suspended-Sediment Yield Related to Water Yield}

\author{
Correlation exists between suspended-sediment yield and water yield \\ in the study area.
}

Suspended sediment is the portion of sediment that is carried in suspension by the turbulent component of streamflow. Suspended-sediment discharge is the rate at which suspended material passes a section of a stream.

Suspended-sediment samples were collected during various flow conditions at 17 sites throughout the study area (fig. 9.9-1). Drainage areas at these sites ranged from 32 to 5,090 square miles. Figure 9.9-2 shows the relation of stream yield to the suspendedsediment yield.
The energy available to transport suspended sediment increases as the stream velocity increases. The size and availability of sediment along with stream velocity determine the suspended-sediment yield. Over 93 percent of the suspended sediment was silt and clay size (finer than 0.062 millimeters) in 28 of 39 particle-size analyses. The remaining 11 samples consisted of 78 to 88 percent silt- and claysized material. 


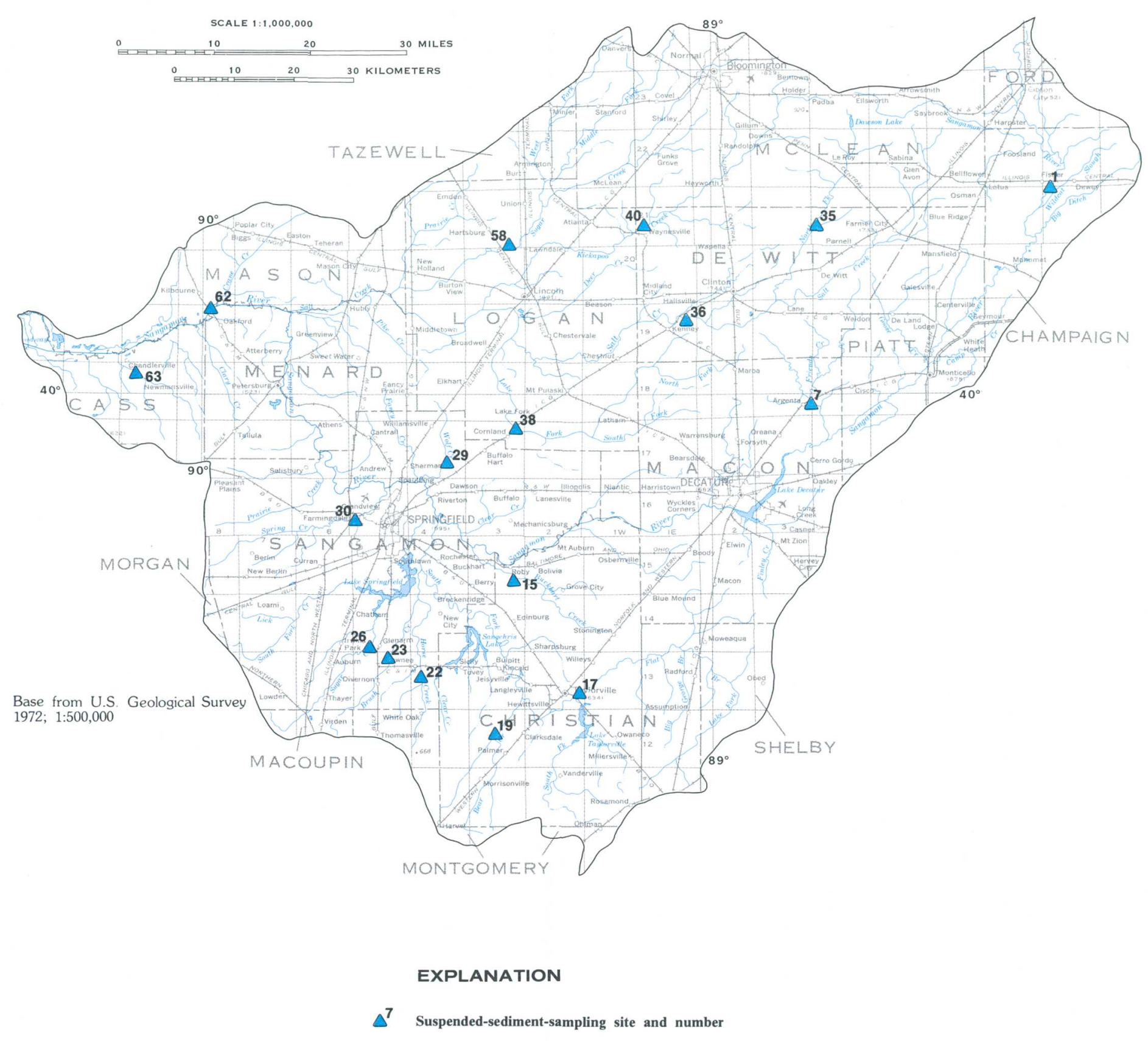

Figure 9.9-1 Suspended-sediment sampling site locations.

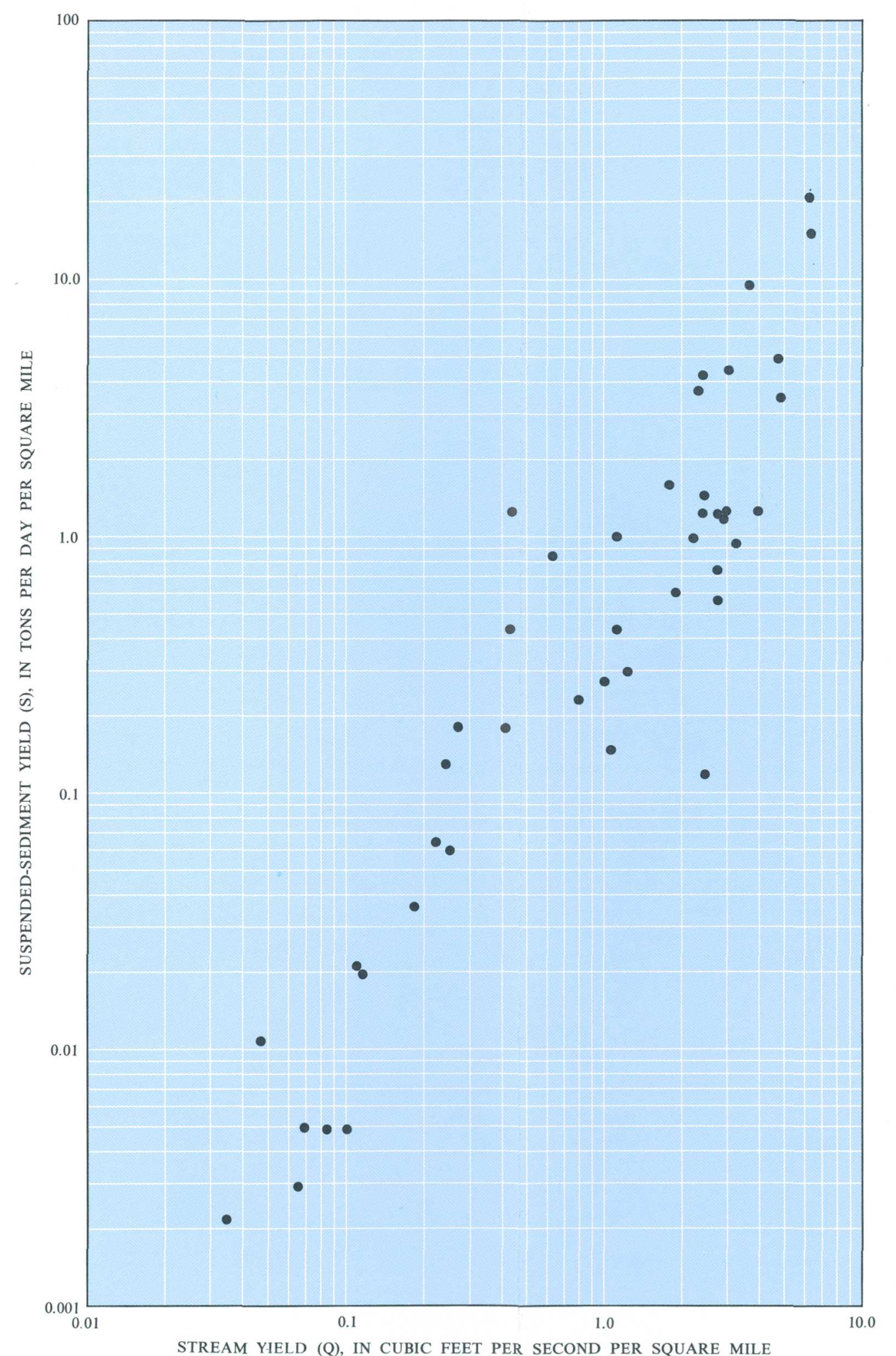

Figure 9.9-2 Relation of stream yield to suspended-sediment yield. 


\title{
10.0 GROUND-WATER QUANTITY
}

\section{Ground Water is Found in Bedrock and Unconsolidated Aquifers}

\author{
The only aquifer of high potential ground-water yield in Area 28 is the sand \\ and gravel aquifer of the buried Mahomet Bedrock Valley. Yields from bedrock \\ aquifers are small.
}

Ground water is recharged by seepage into the earth from precipitation, ponds, and rivers. Seepage occurs through the earth's surface material or directly into sand and gravel or bedrock aquifers at outcrop areas (fig. 10.0-1) (Selkregg and Kempton, 1958).

Ground water is obtained from unconsolidated deposits of sand and gravel in the glacial drift or buried bedrock valleys in almost all of Area 28. Some wells tap bedrock formations of limestone or sandstone. The only aquifer of high potential yield is the sand and gravel aquifer in the buried Mahomet Bedrock Valley (figs. 10.0-2 and 10.0-3).
Most unconsolidated or sand and gravel aquifers in central Illinois (fig. 10.0-3) were deposited by meltwater from glaciers. The sand and gravel was deposited mainly in valleys leading away from the melting ice including the buried Mahomet Bedrock Valley.

Thin sandstone and limestone beds lying directly under the unconsolidated material yield small quantities of water (fig. 10.0-4). Wells tapping these rocks commonly yield less than 25 gallons per minute. Deeper rocks contain water which is too highly mineralized for most uses (Smith and Stall, 1975).

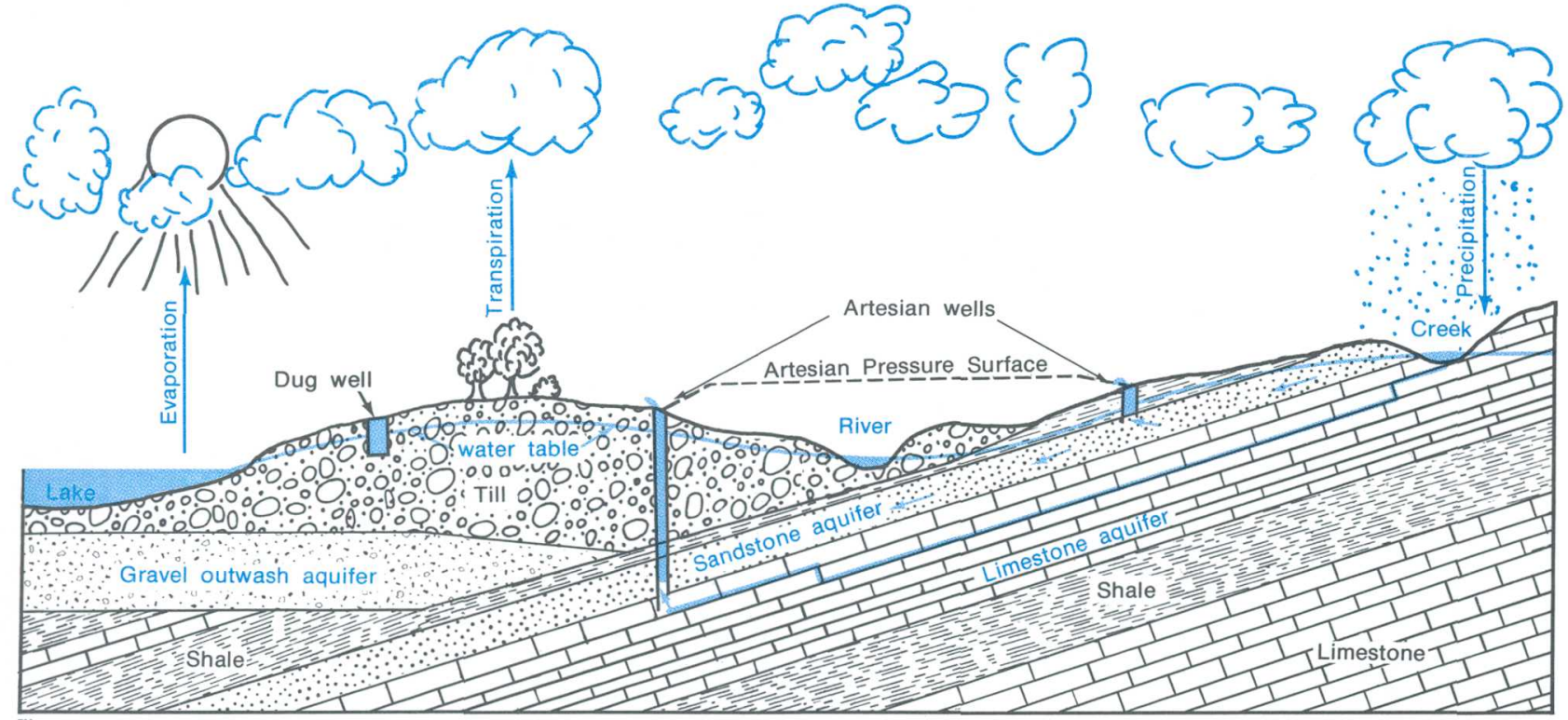

Illustration from Selkregg and Kampton, 1958.

Figure 10.0-1 Hypothetical geologic section showing source, movement, and occurrence of groundwater. 


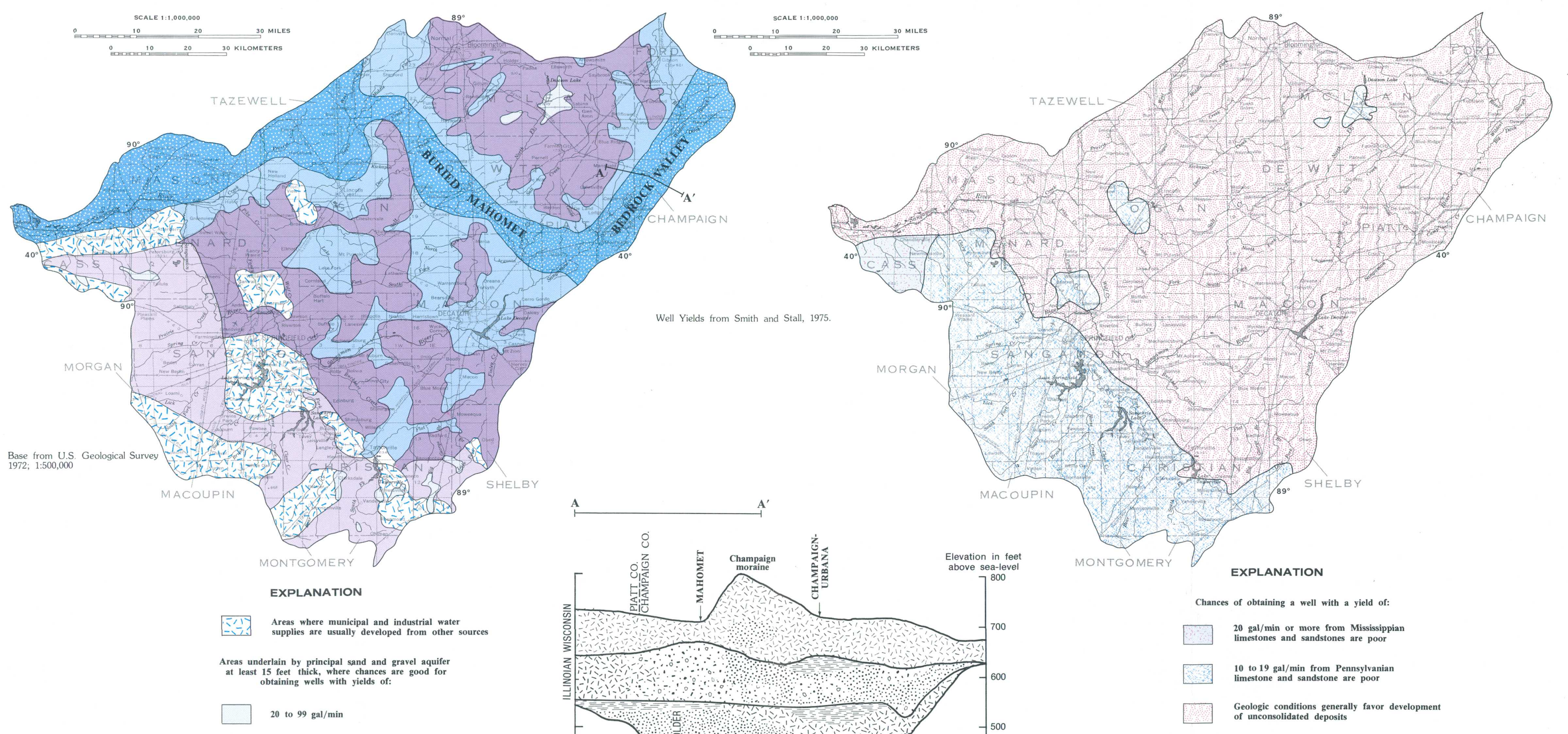

$\square 100$ to $499 \mathrm{gal} / \mathrm{min}$

$500 \mathrm{gal} / \mathrm{min}$ or greater

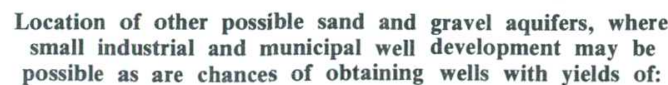

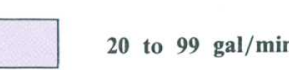

$100 \mathrm{gal} / \mathrm{min}$ or greater

Figure 10.0-4 Yields of bedrock aquifers (shallow dolomites and Mississippian and Pennsylvanian aquifers). 


\subsection{GROUND-WATER QUALITY}

\section{Water Quality Analyzed for 41 Municipal Supply Wells}

\section{Iron, manganese, nitrate, and dissolved solids exceeded the U.S. Environmental Protection Agency criteria at many locations.}

Data for 41 municipal supply wells (fig. 11.0-1) sampled for 18 organic and inorganic constituents and physical properties are shown in table 11.0-1. The U.S. Environmental Protection Agency (USEPA) drinking water criteria (table 11.0-1) for water quality were exceeded for iron at 36 wells, manganese at 25 wells, nitrates at 6 wells, and dissolved solids at 15 wells. All but two wells, numbers 17 and 34, tap unconsolidated (sand and gravel) aquifers.

Iron and manganese concentrations exceeded the USEPA criteria in well waters throughout the study area. The six wells in which the nitrate criterion was exceeded were scattered throughout the study area which indicates localized problems. Dissolved-solids concentrations exceeded the USEPA criterion in 15 of the 41 wells. Dissolved-solids concentrations generally increased toward the northeast. The average dissolved-solids concentration in the Bloomington Ridged Plain division was 517 milligrams per liter $(\mathrm{mg} / \mathrm{L})$ and in the Springfield Plain was $400 \mathrm{mg} / \mathrm{L}$.

Precipitation infiltrates the ground and dissolves various minerals. In general, the deeper the water penetrates, or the farther it moves from the point of entry into the ground, the more mineralized it becomes.

Hardness is derived from the dissolution of calcium and magnesium carbonates. Hardness concentrations for the 41 ground-water wells sampled ranged from 126 to $600 \mathrm{mg} / \mathrm{L}$ as calcium carbonate. Durfor and Becker (1964) have categorized hardness as follows: 0 to $60 \mathrm{mg} / \mathrm{L}$ is soft, 62 to $120 \mathrm{mg} / \mathrm{L}$ is moderately hard, 121 to $180 \mathrm{mg} / \mathrm{L}$ is hard, and over $180 \mathrm{mg} / \mathrm{L}$ is very hard. 


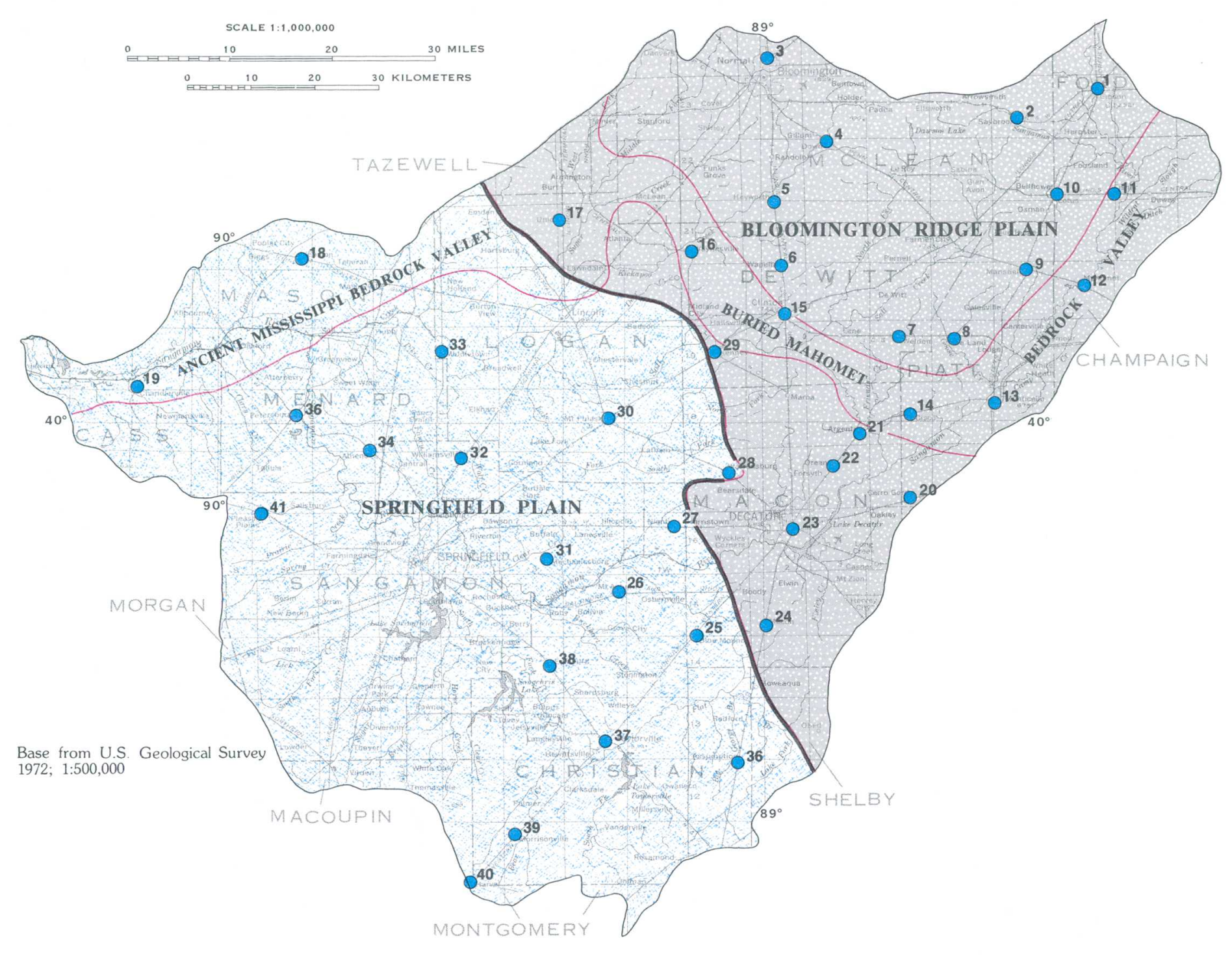

EXPLANATION

- Muncipal ground-water supply sampled

Delineates bedrock valley

Boundary between major
physiographic regions

Figure 11.0-1 Ground-water sites.
Table 11.0-1 Concentrations (in milligrams per liter) of various constituents in municipal wells in Area 28 (from Larson, 1963) Numbers in parenthesis below constifuent is maximumn - limit recommended

\begin{tabular}{|c|c|c|c|c|c|c|c|c|c|c|c|c|c|c|c|c|c|c|}
\hline city & 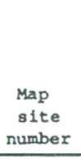 & & 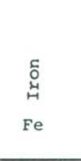 & 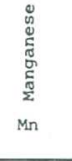 & 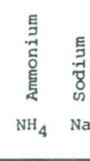 & 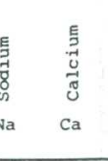 & 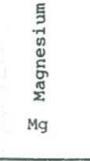 & 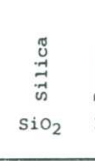 & & & & 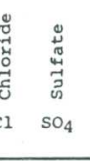 & & 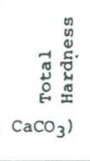 & & & 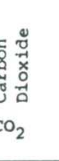 & $\overbrace{\mathrm{F}}^{\circ}$ \\
\hline 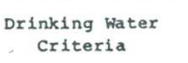 & & & $(0.3)$ & $(.05)$ & & & & & & & (10) 12 & & & & (5500) & (5.9) & & \\
\hline Gibson city & , & & 1.0 & 0.0 & 0.1 & $\begin{array}{lll}6 & 64.7\end{array}$ & 33.9 & 18 & & 0.2 & 3.5 & $2 \quad 27$ & 280 & 301 & 341 & & 45 & \\
\hline saybrook & 2 & & .1 & .1 & $\mathrm{Tx} \quad 1$ & $17 \quad 124.0$ & 46.7 & 19 & & .12 & 28.72 & $24 \quad 133$ & ${ }^{344}$ & 502 & 620 & & 99 & 53.0 \\
\hline Norma1 & 3 & IZC1P & 11.0 & .3 & $.8 x$ & 10185.6 & 52.5 & 140 & 0.1 & .1 & .3 & 13224 & 452 & 680 & 789 & & & \\
\hline Douns & 4 & Arc1 & 2.6 & .0 & 8.44 & $\begin{array}{ll}45 & 95.0\end{array}$ & 40.0 & 23 & .6 & .4 & 1.1 & $5 \quad 1$ & 508 & 402 & 514 & & & 56.0 \\
\hline Heyworth & 5 & In & 3.3 & .0 & $5.210^{7}$ & $07 \quad 71.6$ & 29.3 & 21 & & .3 & .49 & 363 & ${ }^{408}$ & 300 & 590 & $7.4 \quad 4$. & 42 & 53.5 \\
\hline wape 11a & 6 & I & 5.0 & .1 & 4.01 & 1384.0 & 35.0 & & $\mathrm{Tr}$ & .3 & 1.0 & $2 \quad 1$ & 392 & 357 & 410 & & & 53.5 \\
\hline Heldon & 7 & & 1.8 & .0 & 3.162 & $62 \quad 68.1$ & 23.9 & 23 & & .5 & .1 & $6 \quad 1$ & ${ }_{404}^{404}$ & 269 & 445 & & & 55.3 \\
\hline Deland & 8 & ATC 1z & 2.4 & .0 & & $80 \quad 106.0$ & 51.1 & 29 & .2 & .4 & .6 & $17 \quad 1$ & 624 & 475 & 655 & & & 56.0 \\
\hline Mansfield & 9 & & 1.1 & .0 & $1.0 \quad 55$ & $53 \quad 72.0$ & 28.6 & 21 & & .3 & .2 & $12 \quad 2$ & 396 & 298 & 426 & & & 54.0 \\
\hline Be11f 10wer & 10 & & 1.4 & .0 & $\operatorname{Tx} \quad 1$ & $15 \quad 69.5$ & 35.1 & 14 & .3 & .4 & 1.2 & $5 \quad 18$ & ${ }^{324}$ & 318 & 352 & & & 54.0 \\
\hline Fisher & 11 & AIR & 1.9 & $\mathrm{Tx}$ & 14.0 & $\begin{array}{ll}8 & 92.9\end{array}$ & 34.9 & 29 & & .2 & .3 & 291 & 336 & 376 & 461 & 7.38 & 9 & 54.5 \\
\hline rahonet & 12 & IA & 2.6 & .1 & .1 & $\begin{array}{lll}9 & 116.4\end{array}$ & 51.2 & 20 & & .1 & .6 & $21 \quad 100$ & 388 & 502 & 545 & & 97 & 53.5 \\
\hline Monticeilo & 13 & $\mathrm{Iz}$ & 1.6 & .1 & .53 & $34 \quad 58.0$ & 29.2 & 12 & .4 & .2 & 1.3 & $5 \quad 1$ & 332 & 265 & 356 & & & 55.5 \\
\hline Cisco & 14 & I & 12.0 & .0 & $24.2 \quad 68$ & 68 & 43.5 & 35 & & .1 & .0 & 27 & 636 & 432 & 657 & & & 54.8 \\
\hline c1inton & 15 & ArC12 & 3.1 & .3 & 2.98 & $83 \quad 71.6$ & 35.8 & 15 & .4 & .3 & $.1=$ & $56 \quad 1$ & 436 & 326 & 523 & & & 55.5 \\
\hline waynesvi11e & 16 & & 3.3 & .0 & 4.36 & $67 \quad 95.6$ & 52.6 & 28 & & .2 & .2 & $4 \quad 16$ & 592 & 456 & 634 & & & 54.6 \\
\hline Union & 17 & & .1 & .1 & .926 & $\begin{array}{ll}26 & 42.3\end{array}$ & 25.3 & 14 & & .4 & 1.0 & $=1$ & 264 & 210 & 280 & $\begin{array}{ll}7.5 \quad 2 .\end{array}$ & 22 & 52.3 \\
\hline Easton & 18 & I & 2.1 & .2 & $\mathrm{Tx}$ & $\begin{array}{ll}3 & 63.1\end{array}$ & 28.2 & 18 & .1 & .2 & 1.0 & 124 & 252 & 274 & 284 & & & 55.0 \\
\hline chandiervil11e & 19 & L & $\pi x$ & .2 & $\mathrm{Tx}$ & 18 115.8 & 44.1 & 18 & & .15 & 57.8 & $\begin{array}{ll}23 & 176\end{array}$ & 248 & 471 & 592 & & & \\
\hline Cerro Gordo & 20 & $\mathrm{Izc1}$ & .8 & $\mathrm{Tx}$ & $\pi x \quad 16$ & $\begin{array}{ll}16 & 85.5\end{array}$ & 35.7 & 14 & & .3 & $1.0=$ & $21 \quad 108$ & ${ }^{244}$ & 320 & 382 & & 62 & 55.0 \\
\hline Argenta & 21 & rzc1 & 1.4 & .0 & 2.09 & $97 \quad 70.5$ & 36.5 & 15 & .2 & .4 & 2.4 & 77 & ${ }^{432}$ & 327 & 572 & & & 55.0 \\
\hline Oreana & 22 & I & 9.1 & $\mathrm{Tx}$ & & & & & & .3 & .4 & 18 & 540 & 372 & 594 & & & 54.5 \\
\hline Decatur & 23 & & 2.6 & .1 & 1.438 & 3874.1 & 33.6 & 15 & .4 & .1 & .5 & $14 \quad 3$ & ${ }_{388}$ & 324 & 404 & & & 55.0 \\
\hline Macon & 24 & Iz & 10.0 & $\pi x$ & 10.266 & $66 \quad 116.5$ & 45.7 & 30 & .9 & . 33 & 38.9 & 1943 & 548 & 480 & 715 & & & 55.5 \\
\hline Blue Mound & 25 & Iz & .7 & .2 & $\mathrm{Tr} \quad 6$ & $\begin{array}{ll}6 & 74.4\end{array}$ & 33.3 & 22 & & .3 &. & $19 \quad 81$ & 224 & 323 & 365 & & & 55.0 \\
\hline yt. Auburn & 26 & $\mathrm{Iz}$ & 2.5 & .3 & .72 & 296.4 & 33.0 & 18 & & .3 & .21 & $\begin{array}{ll}14 & 37\end{array}$ & ${ }^{324}$ & 377 & 417 & $7.1 \quad 6$ & & 54.6 \\
\hline Niantic & 27 & $\mathrm{Iz}$ & 1.8 & $\mathrm{Tx}_{\mathrm{x}}$ & $\begin{array}{ll}\mathrm{Tx} & 22\end{array}$ & 2284.1 & 28.9 & 16 & .1 & .2 & 4.7 & $14 \quad 18$ & 336 & 330 & 416 & & & 59.0 \\
\hline Warrenaburg & ${ }^{28}$ & Iz & 3.1 & .0 & 5.666 & $\begin{array}{ll}652.4 \\
6\end{array}$ & 34.0 & 21 & .4 & .5 & .7 & $6 \quad 1$ & 472 & 321 & 504 & & & 55.5 \\
\hline Kenney & 29 & ArC1 & 1.5 & & & & & & & .4 & .25 & 52 & ${ }_{424}$ & 316 & ${ }_{522}$ & & & 55.0 \\
\hline Mt. Pulaski & 30 & & $\pi x$ & .0 & Tx $\quad 13$ & 1319.2 & 61.5 & 19 & .0 & .24 & 40.53 & $30 \quad 138$ & 360 & 551 & 630 & & & 57.0 \\
\hline Mechanicssurg & 31 & & 1.9 & .1 & & & & & & .2 & .9 & 6 & ${ }_{288}^{283}$ & 330 & 341 & & & 56.0 \\
\hline W1111 ansvvi111e & 32 & I & .4 & .1 & .12 & $\begin{array}{l}285.7 \\
\end{array}$ & 36.3 & 17 & & .2 & .1 & $\begin{array}{ll}3 & 84\end{array}$ & 276 & 364 & 405 & & & \\
\hline Middletown & 33 & IA & 1.6 & .0 & $\begin{array}{ll}1.3 \quad 12 \\
\end{array}$ & $12 \quad 62.9$ & 24.8 & 31 & & .0 & .4 & $8 \quad 1$ & 276 & 260 & 294 & $7.4 \quad 2$ & & 55.6 \\
\hline Athens & 34 & & 16.4 & .1 & $\begin{array}{ll}2.3 & 13\end{array}$ & 1395.1 & 37.9 & ${ }_{21}$ & & .1 & .1 & 756 & 360 & 394 & $\triangle A B$ & & & \\
\hline Petersburg & 35 & $\mathrm{zc1}$ & .4 & .3 & $.2 \quad 28$ & 80 & 40.0 & 18 & & & 14.23 & $\begin{array}{ll}34 & 169\end{array}$ & 252 & 427 & 582 & & & 59.5 \\
\hline Assumption & 36 & Izc1 & 1.9 & .3 & $\mathrm{Tr} \quad 9$ & $9 \quad 91.1$ & 29.4 & 19 & & .3 & .7 & $7 \quad 125$ & 162 & 204 & 272 & & & 54.0 \\
\hline Taylorvillee & 37 & LCIF & .6 & .1 & .034 & 1432.9 & 10.9 & 19 & & & 14.3 & $4 \quad 33$ & 148 & 126 & 234 & & & 55.5 \\
\hline Edinburg & 38 & AIz & 22.5 & .9 & $1.7 \quad 21$ & $\begin{array}{ll}1 & 63.3\end{array}$ & 26.0 & ${ }_{38}$ & & & .4 & $6 \quad 3$ & 304 & 266 & 353 & $\begin{array}{ll}6.6 & 19\end{array}$ & 96 & 53.8 \\
\hline Morri sonvi11 le & 39 & IA & 1.7 & .1 & .120 & 65.0 & 20.5 & ${ }_{21}$ & & .2 & 1.9 & $\begin{array}{ll}8 & 41\end{array}$ & ${ }^{236}$ & 247 & 336 & & 42 & 54.5 \\
\hline Harve 1 & 40 & IA & 4.2 & .2 & Tr $\quad 28$ & 92.1 & 25.1 & 20 & .2 & .2 & 1.0 & $\begin{array}{ll}18 & 57\end{array}$ & 308 & 334 & 417 & & & 57.0 \\
\hline $\begin{array}{l}\text { Pleasant plains } \\
T r=\text { trace }\end{array}$ & 41 & I & 7.4 & 1.1 & & 103.1 & 46.7 & 21 & & & & $14 \quad 47$ & 404 & 450 & 491 & & & 59.5 \\
\hline noval & & & 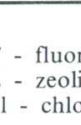 & & & & & & & & & & & & & & & \\
\hline
\end{tabular}





\title{
12.0 WATER-DATA SOURCES
}

12.1 Introduction

\section{NAWDEX, WATSTORE, OWDC, STORET have Water-Data Information}

\author{
Water data are collected in coal areas by a large number of organizations \\ in response to a wide variety of missions and needs.
}

Three activities within the U.S. Geological Survey help to identify and improve access to the vast amount of existing water data.

(1) The National Water Data Exchange (NAWDEX) indexes the water data available from over 400 organizations and serves as a central focal point to help those in need of water data to determine what information already is available.

(2) The National Water Data Storage and Retrieval System (WATSTORE) serves as the central repository of water data collected by the U.S. Geological Survey and contains large volumes of data on the quantity and quality of both surface and ground waters.

(3) The Office of Water Data Coordination
(OWDC) coordinates Federal water-data acquisition activities and maintains a "Catalog of Information on Water Data." To assist in identifying available water-data activities in coal provinces of the United States, special indexes to the catalog are being printed and made available to the public.

In addition to U.S. Geological Survey water data activities, the U.S. Environmental Protection Agency operates a data base called the Water Quality Control Information System (STORET). This data base is used for STOage and RETrieval of data relating to the quality of waterways within and contiguous to the United States.

More detailed explanations of these four activities are given in sections $12.2,12.3,12.4$, and 12.5 . 


\author{
12.0 WATER-DATA SOURCES--Continued \\ 12.2 National Water-Data Exchange (NAWDEX)
}

\title{
NAWDEX Simplifies Access to Water Data
}

\author{
The National Water-Data Exchange (NAWDEX) is a nationwide program managed \\ by the U.S. Geological Survey to assist users of water data or water-related data \\ data in identifying, locating, and acquiring needed data.
}

NAWDEX is a national confederation of wateroriented organizations working together to make their data more readily accessible and to facilitate a more efficient exchange of water data.

Services are available through a Program Office at the Geological Survey National Center in Reston, $\mathrm{Va}$., and a nationwide network of Assistance Centers in 45 states and Puerto Rico, which provide local and convenient access to NAWDEX facilities (fig. 12.2-1). A directory that provides names of organizations and persons to contact, as well as addresses, telephone numbers, and office hours for each of these organizations is available on request (Josefson and Blackwell, 1982).

NAWDEX can assist any organization or individual in identifying and locating water data. To accomplish this service, NAWDEX maintains a computerized Master Water-Data Index (fig. 12.2-2), which identifies sites for which water data are available, the type of data available for each site, and the organization retaining the data. NAWDEX also maintains a Water-Data Sources Directory (fig. 12.2-3) identifying organizations from which water data may be obtained. In addition, NAWDEX has direct access to some large water-data bases of its members and has reciprocal agreements for the exchange of services with others.

Charges for NAWDEX services are assessed at the option of the organization providing the requested data or data service. Search assistance services are provided free by NAWDEX to the greatest extent possible. Charges are assessed, however, for requests requiring computer cost, extensive personnel time, duplicating services, or other costs to NAWDEX providing services. Charges assessed by NAWDEX Assistance Centers will not exceed the direct costs incurred in responding to the data request. Estimates of cost are provided by NAWDEX on request and where costs are anticipated to be substantial.

For additional information concerning the NAWDEX program or its services contact:

\author{
Program Office \\ National Water-Data Exchange (NAWDEX) \\ U.S. Geological Survey \\ 421 National Center \\ 12201 Sunrise Valley Drive \\ Reston, VA 22092 \\ Telephone: (703)860-6031 \\ FTS 928-6031
}

Hours: 7:45 - 4:15 eastern time

NAWDEX ASSISTANCE CENTER Illinois

U.S. Geological Survey

Water Resources Division

Champaign County Bank Plaza

4th floor

102 East Main Street

Urbana, IL 61801

Telephone: (217) 398-5353

FTS 958-5353

Hours: 8:00 - 4:30 central time 


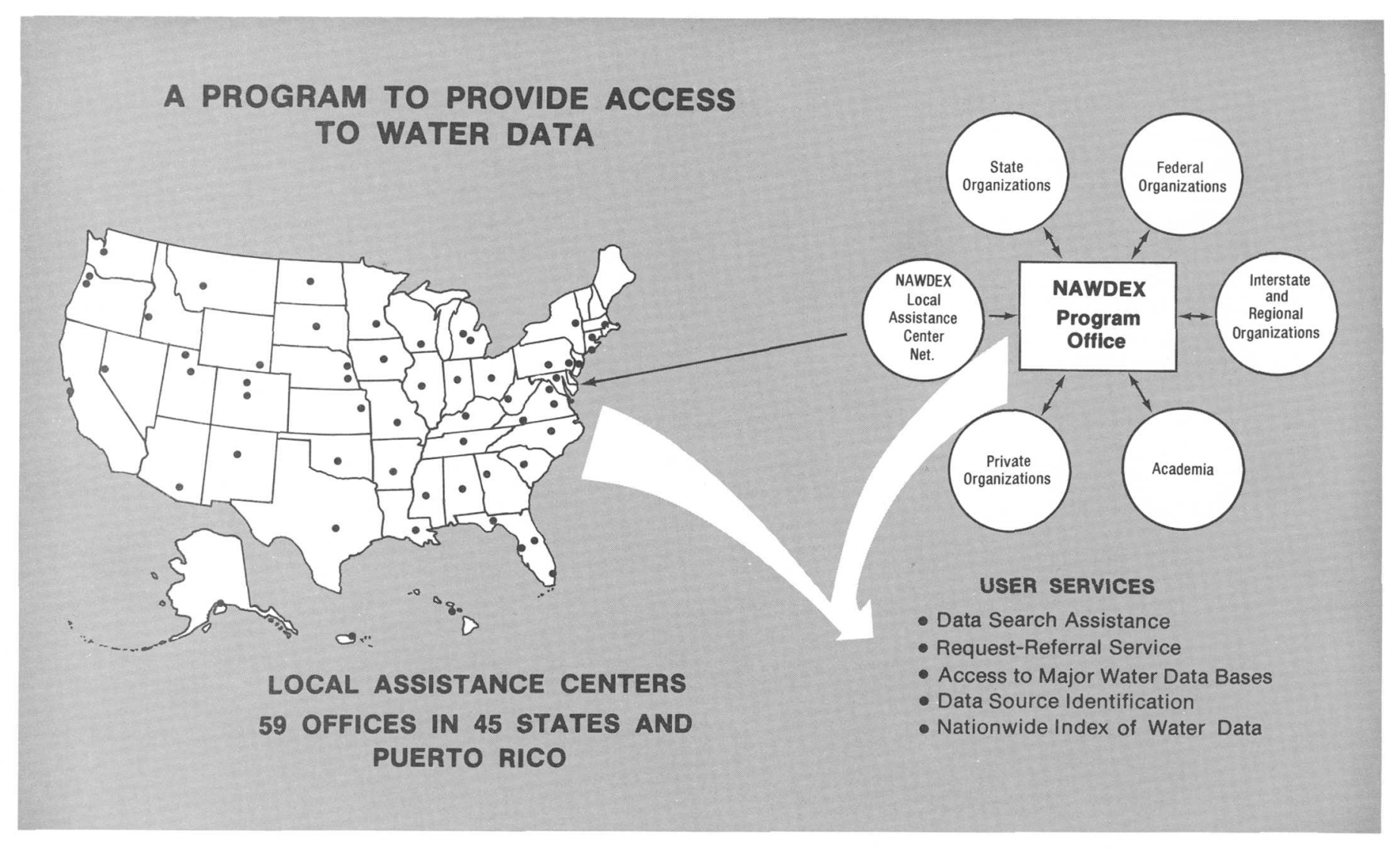

Figure 12.2-1 Access to water data.
MASTER WATER DATA INDEX

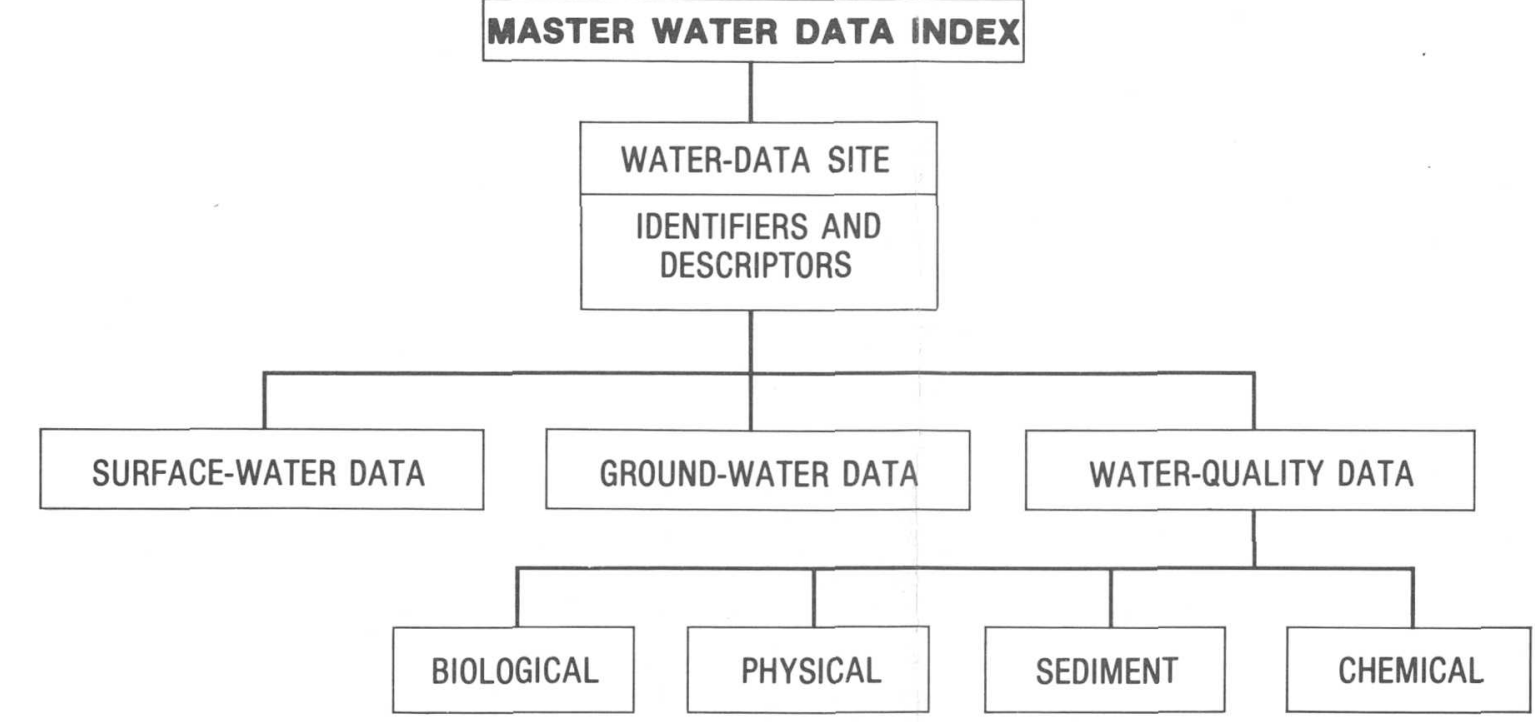

Figure 12.2-2 Master water-data index

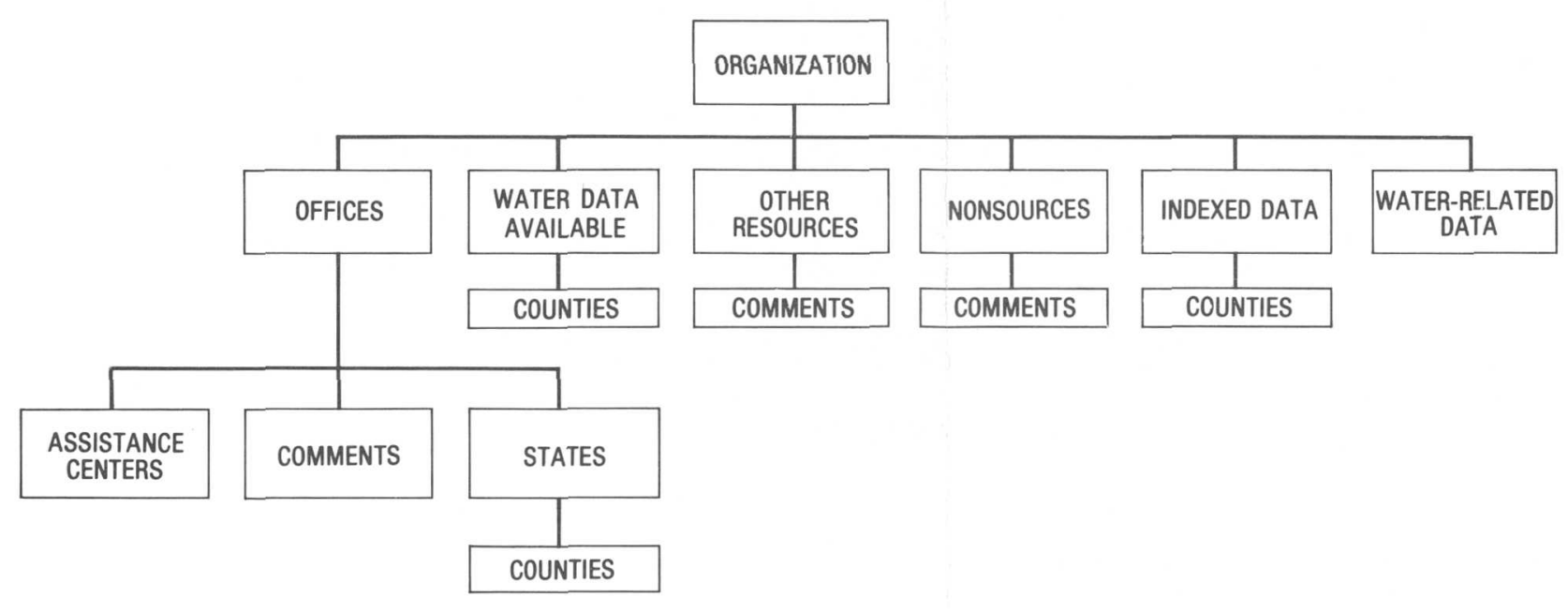

Figure 12.2-3 Water-data sources directory. 


\title{
12.0 WATER-DATA SOURCES--Continued 12.3 WATSTORE
}

\section{WATSTORE Automated Data System}

\author{
The National Water Data Storage and Retrieval System (WATSTORE) of the U.S. \\ Geological Survey provides computerized procedures and techniques for \\ processing water data and provides effective and efficient management of \\ data-releasing activities.
}

The National Water Data Storage and Retrieval System (WATSTORE) was established in November 1971 to computerize the U.S. Geological Survey's existing water-data system and to provide for more effective and efficient management of its datareleasing activities. The system is operated and maintained on the central computer facilities of the Survey at its National Center in Reston, Virginia. Data may be obtained from WATSTORE through the Water Resources Division's 46 district offices. General inquiries about WATSTORE may be directed to:

$$
\begin{aligned}
& \text { Chief Hydrologist } \\
& \text { U.S. Geological Survey } \\
& 437 \text { National Center } \\
& \text { Reston, VA } 22092
\end{aligned}
$$

U.S. Geological Survey

Water Resources Division

Champaign County Bank Plaza 4th Floor

102 East Main Street

Urbana, IL 61801

The Geological Survey currently (1983) collects data at approximately 17,000 stage- or dischargegaging stations, 5,200 surface-water quality stations, 27,000 water-level observation wells, and 7,400 ground-water quality wells. Each year many waterdata collection sites are added and others are discontinued; thus, large amounts of diversified data, both current and historical, are amassed by the Survey's data-collection activities.

The WATSTORE system consists of several files in which data are grouped and stored by common characteristics and data-collection frequencies. The system also is designed to allow for the inclusion of additional data files as needed. Currently, files are maintained for the storage of: (1) Surface-water, quality-of-water, and ground-water measured on a daily or continuous basis; (2) annual peak values for streamflow stations; (3) chemical analyses for surface- and ground-water sites; (4) water parameters measured more frequently than daily; and (5) geologic and inventory data for ground-water sites. In addition, an index file of sites for which data are stored in the system is also maintained. A brief description of each file (fig. 12.3-1) is as follows:

Station Header File: Information pertinent to the identification, location, and physical description of nearly 220,000 sites are contained in this file. All sites for which data are stored in the Daily Values, Peak Flow, Water-Quality, and Unit Values files of WATSTORE are indexed in this file.

Daily Values File: All water-data parameters measured or observed either on a daily or on a continuous basis and numerically reduced to daily values are stored in this file. Instantaneous measurements at fixed-time intervals, daily mean values, and statistics such as daily maximum and minimum values also may be stored. This file currently contains over 200 million daily values including data on streamflow, river stages, reservoir contents, water temperatures, specific conductance, sediment concentrations, sediment discharges, and ground-water levels.

Peak Flow File: Annual maximum (peak) streamflow (discharge) and gage height (stage) values at surface-water sites comprise this file, which currently contains over 400,000 peak observations.

Water-Quality File: Results of more than $\mathbf{1 . 4}$ million analyses of water samples are contained in this file. These analyses contain data for as many as 185 different constituents and physical properties that describe the chemical, physical, biological, and radiochemical characteristics of both surface and ground waters.

Unit Values File: Water parameters measured on a schedule more frequent than daily are stored in this 
file. Rainfall, stream discharge, and temperature data are examples of the types of data stored in the Unit Values File.

Ground-Water Site-Inventory File: This file is maintained within WATSTORE independent of the Water-Quality File and the Daily Values File. contains inventory data about wells, springs, and other sources of ground water. The data included are site location and identification, geohydrologic characteristics, well-construction history, and onetime field measurements such as water temperature. and currently contains data for nearly 780,000 sites.

All data files of the WATSTORE system are maintained and managed on the central computer facilities of the Geological Survey at its Nationa Center. However, data may be entered into and retrieved from WATSTORE at a number of loca-

Remote Job Entry Sites: Almost all of the Wate Resources Division's district offices are equipped with high-speed computer terminals for remote access to the WATSTORE system. These terminals allow each site to enter data into or retrieve data to overnight, depending upon the priority placed on the request. The number of remote job-entry sites is increased as the need arises.

Digital Transmission Sites: Digital recorders are used at many field locations to record valy parameters such as river stages, conductivity, water concentration. Data are recorded on 16-channe paper tape; the tape is removed from the recorder and the data are transmitted over telephone lines to the receiver at Reston, $V a$. The data are re-recorded on magnetic tape for use on the central computer. Extensive testhe for satellte data-collection plattime hydrologic data on a national scale. B operated radios are used as the communication link to the satellite. About 500 data-relay stations are being operated currently (1983) by the Water Resources Division.

Central Laboinatory System: The Water Relocated in Denver, Colo., and Atlanta, Ga, anisyze more than 150,000 water samples per year. These laboratories are equipped to automatically perform chemical analyses ranging from determinations of simple inorganic substances, such as chloride, to complex organic compounds, such as pesticides. As each analysis is completed, the results are verified by laboratory personnel and transmitted via a computer stored in the Water-Quality File of WATSTORE.

Water data are used in many ways by decisionmakers for the management, development, and
monitoring of our water resources. In addition to its data processing, storage, and retrieval capabilities, WATSTORE can provide a variety of useful products ranging from simple tables of data to com-
plex statistical analyses. A minimal fee, plus the plex statistical analyses. A minimal fee, plus the
actual computer cost incurred in producing a desired product, is charged to the requestor for the following product, is

Computer-Printed Tables: Users most often request data from WATSTORE in the form of tables printed by the computer. These tables may contain the availability of data stored in the files. $A$ vicale of formats is available to display the many types of data.

Computer-Printed Graphs: Computer-printed graphs for the rapid analysis or display of data aro anoter grams are available to produce bar graph curves, X-Y point plots, site-location map plots, other similar items by means of line printers.

Statistical Analyses: WATSTORE interfaces with a proprietary statistical package called SAS (Statistical Analysis System, 1976) to provide extenanalysis of variance, transformations, and correlations.

Digital Plotting: WATSTORE also makes use of software systems that prepare data for digital ploting on peripheral offline plotters available at the include hydroter site. Plots that can be obtained $\mathrm{X}$-Y point plots, contour plots, and three-dimensional plots.

Data in Machine-Readable Form: Data stored in WATSTORE can be obtained in machine-readable form for use on other computers or for use as inpu available in the standard format of the WATSTORE system or in the form of punched cards or card images on magnetic tape.

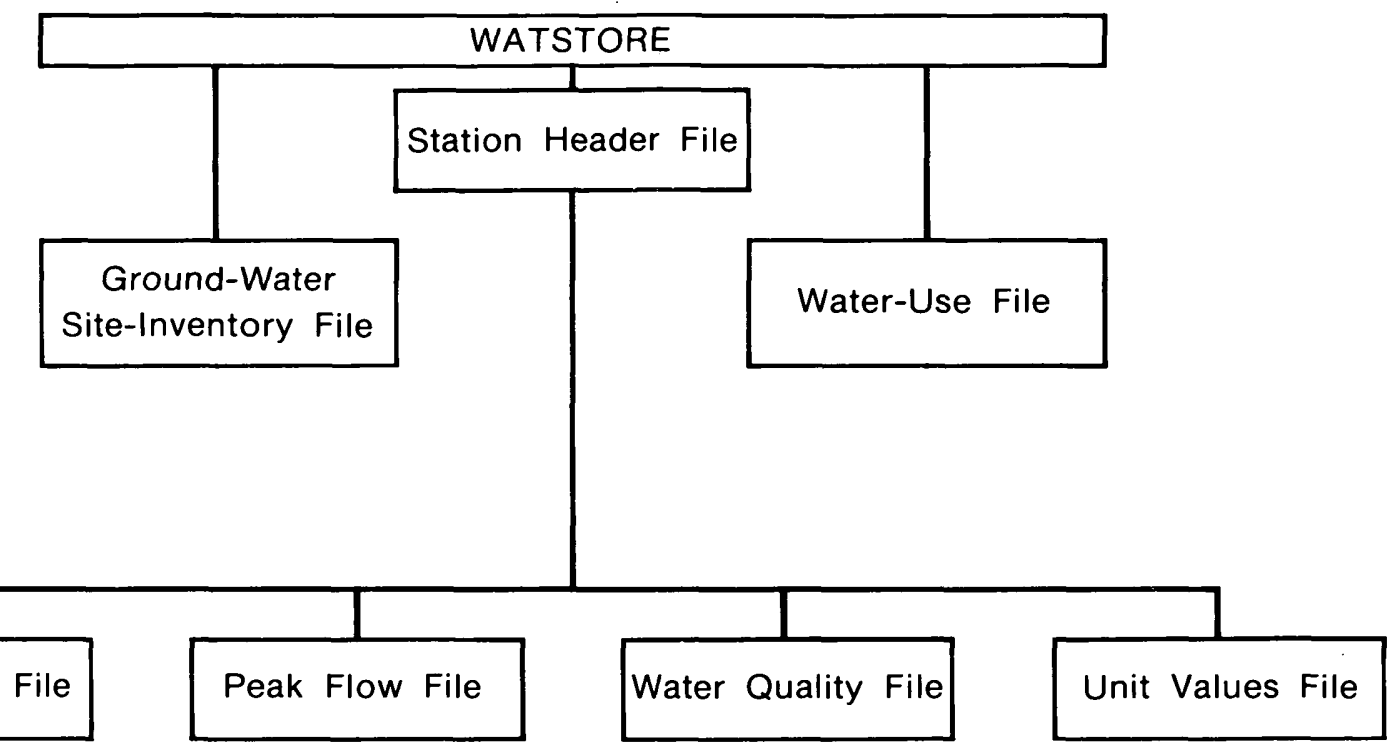

Figure 12.3-1 Index file stored data 


\author{
12.0 WATER-DATA SOURCES--Continued \\ 12.4 Index to Water-Data Activities in Coal Provinces
}

\title{
Water Data Indexed for Coal Provinces
}

\author{
A special index, "Index to Water-Data Activities in Coal \\ Provinces of the United States, " has been published by the \\ Geological Survey Office of Water Data Coordination (OWDC).
}

The "Index to Water-Data Activities in Coal Provinces of the United States" was prepared to provide information on the availability of waterresources data in the major coal provinces of the United States for people developing, managing, and regulating the coal resources of the Nation. It is derived from the "Catalog of Information on Water Data," a computerized information file about waterdata acquisition in the United States, and some other countries. The index consists of five volumes (fig. 12.4-1): volume I, Eastern Coal province; volume II, Interior Coal province; volume III, Northern Great Plains and Rocky Mountain Coal provinces; volume IV, Gulf Coast Coal province; and volume V, Pacific Coast and Alaska Coal provinces. The volumes presented aid the user in obtaining data for evaluating the effects of coal mining on water resources and in developing plans for meeting additional waterdata needs.

Each volume of the special index consists of four parts: Part A, Streamflow and Stage Stations; Part B, Quality of Surface-Water Stations; Part C, Quality of Ground-Water Stations; and Part D, Areal Investigations and Miscellaneous Activities. Information given for each activity in Parts A-C includes (1) identification and location of the station, (2) major types of data collected, (3) frequency of data collection, (4) form in which the data are stored, and (5) agency or organization reporting the activity. Part D summarizes areal hydrologic investigations and water-data activities not included in the other parts of the index. The agencies that submitted the information, agency codes, and the number of activities reported by type are shown in a table.

Assistance in obtaining additional information from the Catalog file or water data is available through the National Water-Data Exchange (NAWDEX) (see section 12.2).

Further information on the index volumes and their availability may be obtained from:

\author{
U.S. Geological Survey \\ Water Resources Division \\ Champaign County Bank Plaza \\ 4th floor \\ 102 East Main Street \\ Urbana, IL 61801
}

Telephone: (217) 398-5353

FTS 958-5353

or

Office of Surface Mining, Region III

U.S. Department of the Interior

U.S. Court and Post Office Building 46 East Ohio Street

Indianapolis, IN 46204

Telephone: (317) 269-2631

FTS 331-2600 


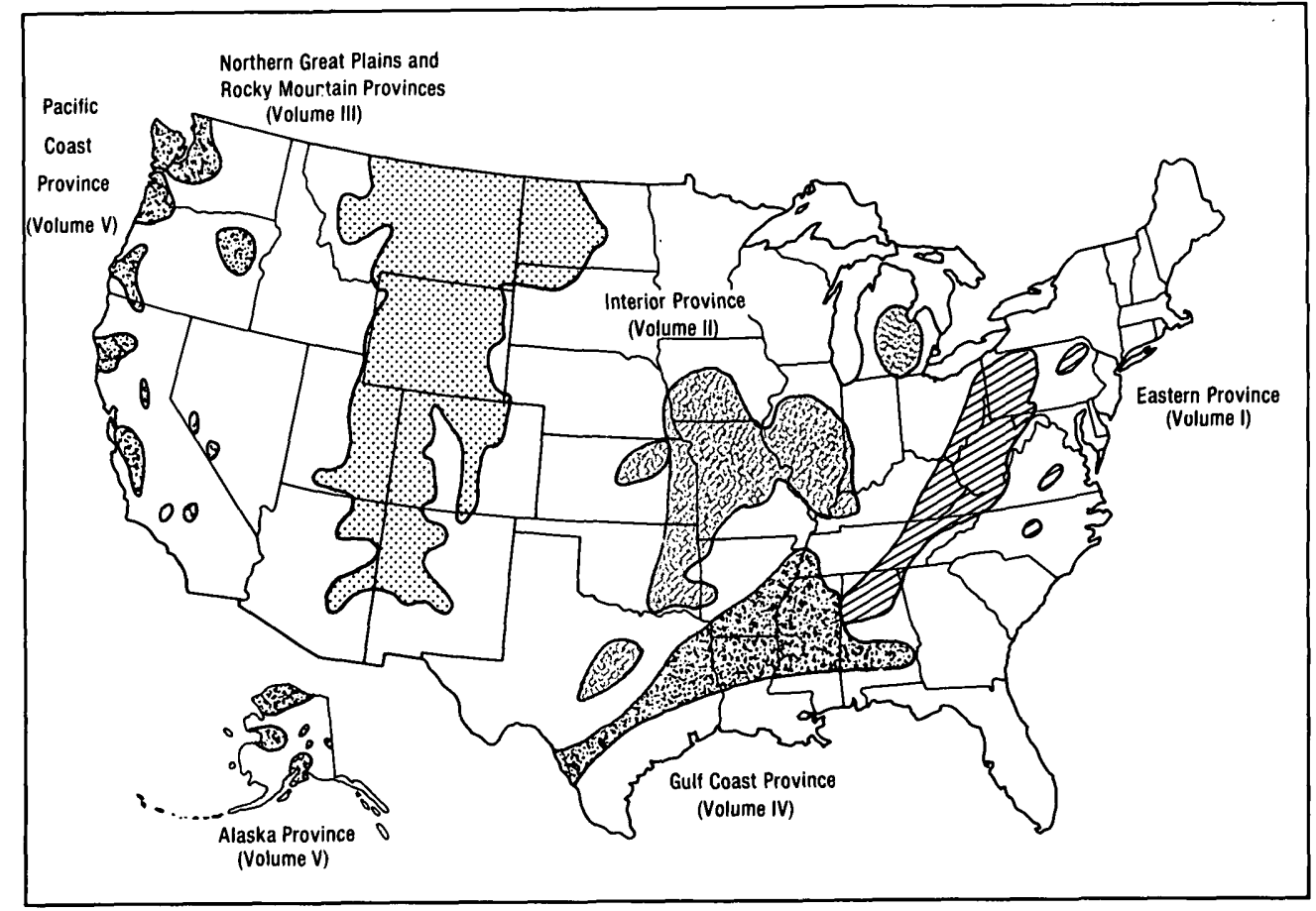

Figure 12.4-1 Index volumes and related provinces. 


\author{
12.0 WATER-DATA SOURCES--Continued \\ 12.5 STORET
}

\title{
STORET is U.S. Environmental Protection Agency Computerized Data Base System
}

\author{
STORET is the computerized data base system that is maintained by the \\ U.S. Environmental Protection Agency. The system is used to store \\ many kinds of water-quality data.
}

\begin{abstract}
"STORET is a computerized data base system maintained by the U.S. Environmental Protection Agency (EPA) for the STOrage and RETrieval of data relating to the quality of the waterways within and contiguous to the United States." The system is used to store data on water quality, water-quality standards, point sources of pollution, pollutioncaused fish kills, waste abatement needs, implementation schedules, and other water-quality related information. The Water Quality File (WQF) is the most widely used STORET file.
\end{abstract}

The data in the Water Quality File is collected through cooperative programs involving EPA, State water pollution control authorities, and other governmental agencies. The U.S. Geological Survey, the U.S. Forest Service, the U.S. Army Corps of Engineers, the Bureau of Reclamation, and the Tennessee Valley Authority all use STORET's WQF to store and retrieve data collected through their waterquality monitoring programs.

There are 1,800 water-quality parameters defined within STORET's WQF. In 1976 there were data from over 200,000 unique collection points in the system. Figure 12.5-1 illustrates the groups of parameters and number of observations that are in the WQF.

State, Federal, interstate, and local government agencies can become STORET users. Information on becoming a user of the system can be obtained by contacting the EPA. The point of contact for Region V is:

\section{Director}

Surveillance and Analysis Division Environmental Protection Agency 230 S. Dearborn Street Chicago, IL 60604

(312) 353-6738

Source: Handbook Water Quality Control Information System (STORET), U.S. Environmental Protection Agency, Office of Water and Hazardous Materials, Washington, D.C. 20460 


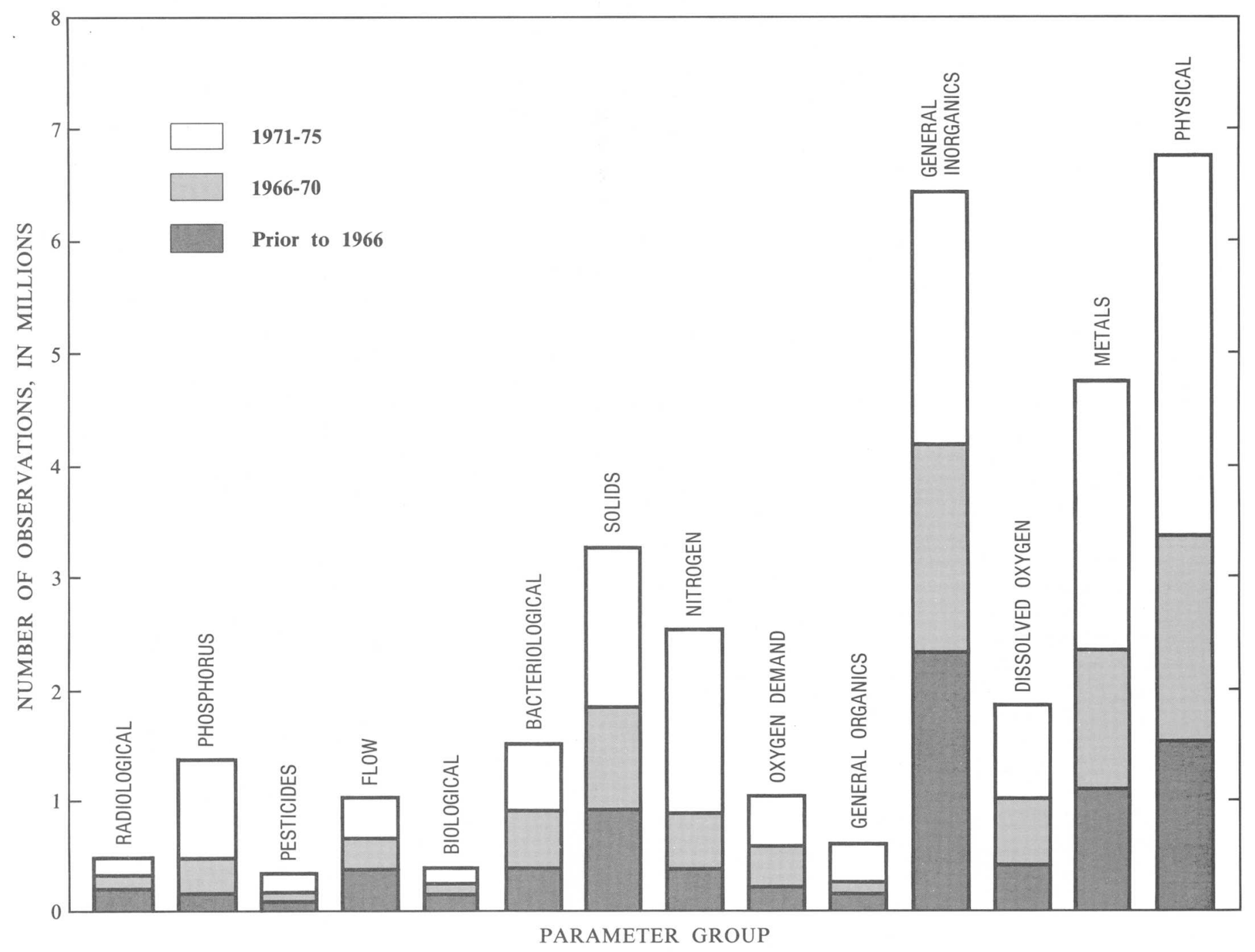

Figure 12.5-1 Parameter groups and number of observations in the Water Quality File. 


\subsection{SURFACE-WATER DISCHARGE SITES AND SURFACE-WATER- \\ QUALITY SAMPLING SITES IN THE STUDY AREA--Continued}

\begin{tabular}{|c|c|c|c|c|c|}
\hline $\begin{array}{l}\text { Map } \\
\text { site } \\
\text { number }\end{array}$ & $\begin{array}{l}\text { USGS } \\
\text { station } \\
\text { number }\end{array}$ & Station name and location & $\begin{array}{l}\text { Drainage } \\
\text { area } \\
\left(\mathrm{mi}^{2}\right)\end{array}$ & $\begin{array}{l}\text { Type } \\
\text { of } \\
\text { data }\end{array}$ & $\begin{array}{l}\text { Years } \\
\text { of } \\
\text { record }\end{array}$ \\
\hline 1 & 05570910 & $\begin{array}{l}\text { Sangamon River at Fisher, Ill. } \\
\text { Lat } 40^{\circ} 18^{\prime} 44^{\prime \prime} \text {, long } 88^{\circ} 19^{\prime} 20^{\prime \prime} \text {, sec.5, } \\
\text { T.21 N., R.8.E., Champaign County. }\end{array}$ & 240 & $\begin{array}{l}D \\
W Q\end{array}$ & $\begin{array}{l}1979-81 \\
1979-81\end{array}$ \\
\hline 2 & 05571000 & $\begin{array}{l}\text { Sangamon River at Mahomet, Ill. } \\
\text { Lat } 40^{\circ} 11^{\prime} 30^{\prime \prime}, \text { long } 88^{\circ} 24^{\prime} 00^{\prime \prime} \text {, sec. } 15 \text {, } \\
\text { T.20 N., R.7 E., Champaign County. }\end{array}$ & 362 & $\begin{array}{l}\text { D } \\
\text { WQ }\end{array}$ & $\begin{array}{c}1948-78 \\
1978\end{array}$ \\
\hline 3 & 05571500 & $\begin{array}{l}\text { Goose Creek near De Land, Ill. } \\
\text { Lat } 40^{\circ} 05^{\prime} 40^{\prime \prime} \text {, long } 88^{\circ} 37^{\prime} 52^{\prime \prime} \text {, sec.22, } \\
\text { T.19 N., R.5 E., Piatt County. }\end{array}$ & 47.9 & D & $1952-59$ \\
\hline 4 & 05572000 & $\begin{array}{l}\text { Sangamon River at Monticello, Ill. } \\
\text { Lat } 40^{\circ} 01^{\prime} 51^{\prime \prime}, \text { long } 88^{\circ} 35^{\prime} 20^{\prime \prime}, \text { sec.12, } \\
\text { T.18 N., R.5 E., Piatt County. }\end{array}$ & 550 & $\begin{array}{l}D \\
D\end{array}$ & $\begin{array}{l}1908-12 \\
1914-81\end{array}$ \\
\hline 5 & 05572100 & $\begin{array}{l}\text { Wildcat Creek tributary near } \\
\text { Monticello, Ill. } \\
\text { Lat } 40^{\circ} 01^{\prime} 37^{\prime \prime}, \text { long } 88^{\circ} 38^{\prime} 24^{\prime \prime}, \text { sec.9, } \\
\text { T. } 18 \text { N., R.5 E., Piatt County. }\end{array}$ & .10 & C & $1956-76$ \\
\hline 6 & 05572125 & $\begin{array}{l}\text { Sangamon River at Allerton Park near } \\
\text { Monticello, Ill. } \\
\text { Lat } 40^{\circ} 00^{\prime} 08^{\prime \prime}, \text { long } 88^{\circ} 38^{\prime} 07^{\prime \prime}, \text { sec. } 21 \text {, } \\
\text { T. } 18 \text { N., R.5 E., Piatt County. }\end{array}$ & 573 & WQ & $1979-81$ \\
\hline 7 & 05572450 & $\begin{array}{l}\text { Friends Creek at Argenta, Ill. } \\
\text { Lat } 39^{\circ} 59^{\prime} 21^{\prime \prime}, \text { long } 88^{\circ} 48^{\prime} 18^{\prime \prime}, \text { sec.25, } \\
\text { T.18 N., R.3 E., Macon County. }\end{array}$ & 111 & $\begin{array}{l}\text { D } \\
\text { WQ }\end{array}$ & $\begin{array}{c}1967-81 \\
1981\end{array}$ \\
\hline 8 & 05572500 & 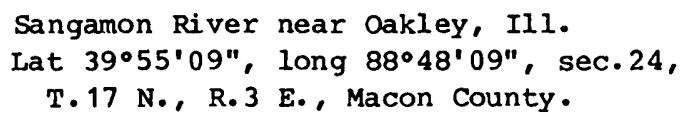 & 774 & $\begin{array}{l}\text { D } \\
\text { F }\end{array}$ & $\begin{array}{l}1951-56 \\
1957-77\end{array}$ \\
\hline 9 & 05573500 & $\begin{array}{l}\text { Sangamon River at Lake Decatur at } \\
\text { Decatur, Ill. } \\
\text { Lat } 39^{\circ} 49^{\prime} 38^{\prime \prime}, \text { long } 88^{\circ} 57^{\prime} 21^{\prime \prime} \text {, sec. 22, } \\
\text { T.16 N., R. } 2 \text { E., Macon County. }\end{array}$ & 925 & $\mathrm{D}$ & $1949-51$ \\
\hline 10 & 05573504 & $\begin{array}{l}\text { Sangamon River at Lake Decatur water } \\
\text { Intake at Decatur, Ill. } \\
\text { Lat } 39^{\circ} 49^{\prime} 44^{\prime \prime} \text {, long } 88^{\circ} 57^{\prime} 35^{\prime \prime}, \text { sec.22, } \\
\text { T.16 N., R.2 E., Macon County. }\end{array}$ & 927 & WQ & $1980-81$ \\
\hline
\end{tabular}

Type of data

D - Daily water discharge record.

C - Water peak stage and discharge record.

WQ - Surface-water-quality-constituents record (temperature not included).

F - Fragmentary water-discharge record (no low-flow values). 


\begin{tabular}{|c|c|c|c|c|c|}
\hline $\begin{array}{l}\text { Map } \\
\text { site } \\
\text { number }\end{array}$ & $\begin{array}{l}\text { USGS } \\
\text { station } \\
\text { number }\end{array}$ & Station name and location & $\begin{array}{l}\text { Drainage } \\
\text { area } \\
\left(\mathrm{mi}^{2}\right)\end{array}$ & $\begin{array}{l}\text { Type } \\
\text { of } \\
\text { data }\end{array}$ & $\begin{array}{l}\text { Years } \\
\text { of } \\
\text { record }\end{array}$ \\
\hline 11 & 05573540 & $\begin{array}{l}\text { Sangamon River at Route } 48 \text { at } \\
\text { Decatur, Ill. } \\
\text { Lat } 39^{\circ} 49^{\prime} 52^{\prime \prime}, \text { long } 88^{\circ} 58^{\prime} 35^{\prime \prime}, \text { sec. } 21 \text {, } \\
\text { T.16 N., R.2 E., Macon County. }\end{array}$ & 938 & WQ & $1979-81$ \\
\hline 12 & 05573600 & $\begin{array}{l}\text { Spring Creek tributary at Decatur, Ill. } \\
\text { Lat } 39^{\circ} 52^{\prime} 56^{\prime \prime}, \text { long } 88^{\circ} 57^{\prime} 13^{\prime \prime}, \text { sec. } 35 \text {, } \\
\text { T.17 N., R.2 E., Macon County. }\end{array}$ & .3 & WQ & 1977 \\
\hline 13 & 05573650 & $\begin{array}{l}\text { Sangamon River near Niantic, Ill. } \\
\text { Lat } 39^{\circ} 47^{\prime} 48^{\prime \prime} \text {, long } 89^{\circ} 06^{\prime} 15^{\prime \prime}, \text { sec.32, } \\
\text { T. } 16 \text { N., R. } 1 \text { E., Macon County. }\end{array}$ & 1,054 & WQ & $1978-81$ \\
\hline 14 & 05573800 & $\begin{array}{l}\text { Sangamon River at Roby, Ill. } \\
\text { Lat } 39^{\circ} 44^{\prime} 32^{\prime \prime} \text {, long } 89^{\circ} 23^{\prime} 57^{\prime \prime}, \text { sec. 14, } \\
\text { T.15 N., R.3 w., Sangamon County. }\end{array}$ & 1,264 & WQ & $1978-81$ \\
\hline 15 & 05573880 & $\begin{array}{l}\text { Buckhart Creek near Rochester, Ill. } \\
\text { Lat } 39^{\circ} 43^{\prime} 56^{\prime \prime}, \text { long } 89^{\circ} 24^{\prime} 06^{\prime \prime}, \text { sec.23, } \\
\text { T.15 N., R.3 W., Christian County. }\end{array}$ & 82.6 & พQ & 1981 \\
\hline 16 & 05574000 & $\begin{array}{l}\text { South Fork Sangamon River near Nokomis, } \\
\text { Ill. } \\
\text { Lat } 39^{\circ} 21^{\prime} 12^{\prime \prime}, \text { long } 89^{\circ} 15^{\prime} 05^{\prime \prime}, \text { sec. } 36 \text {, } \\
\text { T.11 N., R.2 W., Sangamon County. }\end{array}$ & 11.0 & $\begin{array}{l}D \\
C\end{array}$ & $\begin{array}{l}1950-75 \\
1976-81\end{array}$ \\
\hline 17 & 05574500 & $\begin{array}{l}\text { Flat Branch near Taylorville, Ill. } \\
\text { Lat } 39^{\circ} 33^{\prime} 14^{\prime \prime}, \text { long } 89^{\circ} 15^{\prime} 12^{\prime \prime} \text {, sec. } 24 \text {, } \\
\text { T.13 N., R.2 W., Christian County. }\end{array}$ & 276 & $\begin{array}{l}\text { D } \\
\text { WQ }\end{array}$ & $\begin{array}{l}1949-81 \\
1979-81\end{array}$ \\
\hline 18 & 05575000 & 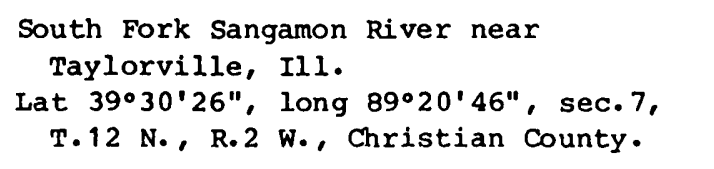 & 434 & $\begin{array}{l}\mathrm{D} \\
\mathrm{D}\end{array}$ & $\begin{array}{l}1908-13 \\
1914-17\end{array}$ \\
\hline 19 & 05575050 & $\begin{array}{l}\text { Bear Creek near Palmer, Ill. } \\
\text { Lat } 39^{\circ} 28^{\prime} 50^{\prime \prime}, \text { long } 89^{\circ} 25^{\prime} 30^{\prime \prime} \text {, sec. } 21 \text {, } \\
\text { T. } 12 \text { N., R. } 3 \text { W., Christian County. }\end{array}$ & 60.0 & WQ & $1979-81$ \\
\hline 20 & 05575500 & $\begin{array}{l}\text { South Fork Sangamon River at Kincaid, } \\
\text { Ill. } \\
\text { Lat } 39^{\circ} 34^{\prime} 44^{\prime \prime}, \text { long } 89^{\circ} 23^{\prime} 31^{\prime \prime} \text {, sec. } 14 \text {, } \\
\text { T. } 13 \text { N., R.3 W., Christian County. }\end{array}$ & 562 & $\begin{array}{l}D \\
D \\
C \\
\text { WQ }\end{array}$ & $\begin{array}{l}1917-34 \\
1944-61 \\
1962-81 \\
1978-81\end{array}$ \\
\hline 21 & 05575570 & $\begin{array}{l}\text { Sangchris Lake near New City, Ill. } \\
\text { Lat } 39^{\circ} 39^{\prime} 00^{\prime \prime}, \text { long } 89^{\circ} 28^{\prime} 40^{\prime \prime} \text {, sec. } 19 \text {, } \\
\text { T.14 N., R.3 W., Christian County. }\end{array}$ & (a) & WQ & $1980-81$ \\
\hline
\end{tabular}

(a) Indeterminate

\subsection{SURFACE-WATER DISCHARGE SITES AND SURFACE-WATER-QUALITY SAMPLING SITES IN THE STUDY AREA--Continued}




\subsection{SURFACE-WATER DISCHARGE SITES AND SURFACE-WATER- QUALITY SAMPLING SITES IN THE STUDY AREA--Continued}

\begin{tabular}{|c|c|c|c|c|c|}
\hline $\begin{array}{l}\text { Map } \\
\text { site } \\
\text { number }\end{array}$ & $\begin{array}{l}\text { USGS } \\
\text { station } \\
\text { number }\end{array}$ & Station name and location & $\begin{array}{l}\text { Drainage } \\
\text { area } \\
\left(\mathrm{mi}^{2}\right)\end{array}$ & $\begin{array}{l}\text { Type } \\
\text { of } \\
\text { data }\end{array}$ & $\begin{array}{l}\text { Years } \\
\text { of } \\
\text { record }\end{array}$ \\
\hline 22 & 05575800 & $\begin{array}{l}\text { Horse Creek at Pawnee, Ill. } \\
\text { Lat } 39^{\circ} 34^{\prime} 56^{\prime \prime}, \text { long } 89^{\circ} 34^{\prime} 20^{\prime \prime}, \text { sec.18, } \\
\text { T.13 N., R.4 W., Sangamon County. }\end{array}$ & 52.2 & $\begin{array}{l}\text { D } \\
\text { WQ }\end{array}$ & $\begin{array}{c}1968-81 \\
1981\end{array}$ \\
\hline 23 & 05575830 & $\begin{array}{l}\text { Brush Creek near Divernon, Ill. } \\
\text { Lat } 39^{\circ} 35^{\prime} 50^{\prime \prime}, \text { long } 89^{\circ} 37^{\prime} 48^{\prime \prime} \text {, sec. } 3 \text {, } \\
\text { T.13 N., R.5 W., Sangamon County. }\end{array}$ & 32.4 & $\begin{array}{l}\text { D } \\
\text { WQ }\end{array}$ & $\begin{array}{l}1974-81 \\
1980-81\end{array}$ \\
\hline 24 & 05576000 & $\begin{array}{l}\text { South Fork Sangamon River near } \\
\text { Rochester, Ill. } \\
\text { Lat } 39^{\circ} 44^{\prime} 32^{\prime \prime}, \text { long } 89^{\circ} 34^{\prime} 02^{\prime \prime}, \text { sec. } 20 \text {, } \\
\text { T. } 15 \text { N., R.4 W., Sangamon County. }\end{array}$ & 867 & $\begin{array}{l}\text { D } \\
\text { WQ }\end{array}$ & $\begin{array}{l}1949-81 \\
1979-81\end{array}$ \\
\hline 25 & 05576022 & $\begin{array}{l}\text { South Fork Sangamon River below } \\
\text { Rochester, Ill. } \\
\text { Lat } 39^{\circ} 45^{\prime} 50^{\prime \prime}, \text { long } 89^{\circ} 33^{\prime} 43^{\prime \prime} \text {, sec. } 8 \text {, } \\
\text { T.15 N., R.4 W., Sangamon County. }\end{array}$ & 870 & WQ & $1978-81$ \\
\hline 26 & 05576190 & $\begin{array}{l}\text { Sugar Creek near Glenarm, Ill. } \\
\text { Lat } 39^{\circ} 36^{\prime} 49^{\prime \prime}, \text { long } 89^{\circ} 41^{\prime} 05^{\prime \prime}, \text { sec.32, } \\
\text { T.14 N., R.5 W., Sangamon County. }\end{array}$ & 57.5 & WQ & $1979-81$ \\
\hline 27 & 05576250 & $\begin{array}{l}\text { Sugar Creek near Springfield, Ill. } \\
\text { Lat } 39^{\circ} 46^{\prime} 48^{\prime \prime} \text {, long } 89^{\circ} 35^{\prime} 20^{\prime \prime} \text {, sec. } 6 \text {, } \\
\text { T.15 N., R. } 4 \text { W., Sangamon County. }\end{array}$ & 270 & WQ & $1979-81$ \\
\hline 28 & 05576500 & $\begin{array}{l}\text { Sangamon River at Riverton, Ill. } \\
\text { Lat } 39^{\circ} 50^{\prime} 34^{\prime \prime}, \text { long } 89^{\circ} 32^{\prime} 52^{\prime \prime} \text {, sec.16, } \\
\text { T.16 N., R.4 W., Sangamon County. }\end{array}$ & 2,618 & $\begin{array}{l}\text { D } \\
\text { D } \\
\text { C } \\
\text { WQ }\end{array}$ & $\begin{array}{l}1908-12 \\
1914-56 \\
1957-81 \\
1978-81\end{array}$ \\
\hline 29 & 05576600 & $\begin{array}{l}\text { Wolf Creek near Sherman, Ill. } \\
\text { Lat } 39^{\circ} 53^{\prime} 47^{\prime \prime} \text {, long } 89^{\circ} 31^{\prime} 00^{\prime \prime}, \text { sec.26, } \\
\text { T.17 N., R.4 W., Sangamon County. }\end{array}$ & 36.6 & WQ & 1981 \\
\hline 30 & 05577500 & $\begin{array}{l}\text { Spring Creek at Springfield, Ill. } \\
\text { Lat } 39^{\circ} 48^{\prime} 57^{\prime \prime} \text {, long } 89^{\circ} 41^{\prime} 57^{\prime \prime} \text {, sec. } 30 \text {, } \\
\text { T.16 N., R.5 W., Sangamon County. }\end{array}$ & 107 & $\begin{array}{l}\text { D } \\
\text { WQ }\end{array}$ & $\begin{array}{l}1948-81 \\
1979-81\end{array}$ \\
\hline 31 & 05577505 & $\begin{array}{l}\text { Spring Creek at Burns Lane Bridge at } \\
\text { Springfield, Ill. } \\
\text { Lat } 39^{\circ} 49^{\prime} 16^{\prime \prime} \text {, long } 89^{\circ} 41^{\prime} 16^{n} \text {, sec. } 20 \text {, } \\
\text { T.16 N., R.5 W., Sangamon County. }\end{array}$ & 109 & $W Q$ & $1979-81$ \\
\hline 32 & 05577520 & $\begin{array}{l}\text { Spring Creek tributary at Springfield, } \\
\text { Ill. } \\
\text { Lat } 39^{\circ} 50^{\circ} 04^{\prime \prime}, \text { long } 89^{\circ} 37^{\prime} 14^{\prime \prime} \text {, sec.14, } \\
\text { T.16 N., R.5 W., Sangamon County. }\end{array}$ & 1.27 & C & $1971-76$ \\
\hline
\end{tabular}




\begin{tabular}{|c|c|c|c|c|c|}
\hline $\begin{array}{l}\text { Map } \\
\text { site } \\
\text { number }\end{array}$ & $\begin{array}{l}\text { USGs } \\
\text { station } \\
\text { number }\end{array}$ & Station name and location & $\begin{array}{l}\text { Drainage } \\
\text { area } \\
\left(m i^{2}\right)\end{array}$ & $\begin{array}{l}\text { Type } \\
\text { of } \\
\text { data }\end{array}$ & $\begin{array}{l}\text { Years } \\
\text { of } \\
\text { record }\end{array}$ \\
\hline 33 & 05577700 & $\begin{array}{l}\text { Sangamon River tributary at Andrew, } \\
\text { Ill. } \\
\text { Lat } 39^{\circ} 53^{\prime} 45^{\prime \prime}, \text { long } 89^{\circ} 38^{\prime} 50^{\prime \prime}, \text { sec. } 27 \text {, } \\
\text { T.17 N., R.5 W., Sangamon County. }\end{array}$ & 1.50 & C & $1956-80$ \\
\hline 34 & 05578000 & $\begin{array}{l}\text { Sangamon River at Petersburg, Ill. } \\
\text { Lat } 40^{\circ} 00^{\prime} 37^{\prime \prime} \text {, long } 89^{\circ} 50^{\prime} 42^{\prime \prime} \text {, sec. } 13 \text {, } \\
\text { T. } 18 \text { N., R. R W., Menard County. }\end{array}$ & 3,063 & $\begin{array}{l}\text { D } \\
\text { WQ }\end{array}$ & $\begin{array}{l}1948-49 \\
1978-81\end{array}$ \\
\hline 35 & 05578200 & $\begin{array}{l}\text { North Fork Salt Creek near Farmer } \\
\text { City, Ill. } \\
\text { Lat } 40^{\circ} 15^{\prime} 11^{\prime \prime}, \text { long } 88^{\circ} 47^{\prime} 43^{\prime \prime} \text {, sec. } 30 \text {, } \\
\text { T.21 N., R.4 E., De Witt County. }\end{array}$ & 97.0 & WQ & 1981 \\
\hline 36 & 05578500 & $\begin{array}{l}\text { Salt Creek near Rowell, Ill. } \\
\text { Lat } 40^{\circ} 06^{\prime} 54^{\prime \prime}, \text { long } 89^{\circ} 02^{\prime} 57^{\prime \prime}, \text { sec. } 11 \text {, } \\
\text { T. } 19 \text { N., R. } 1 \text { E., De Witt County. }\end{array}$ & 335 & $\begin{array}{l}\text { D } \\
\text { WQ }\end{array}$ & $\begin{array}{l}1943-81 \\
1978-81\end{array}$ \\
\hline 37 & 05579000 & $\begin{array}{l}\text { Salt Creek near Kenney, Ill. } \\
\text { Lat } 40^{\circ} 07^{\prime} 16^{\prime \prime}, \text { long } 89^{\circ} 07^{\prime} 24^{\prime \prime} \text {, secs.7 } \\
\quad \text { \& } 8 . \text { T.19 N., R. } 1 \text { E., De Witt County. }\end{array}$ & 390 & D & $1908-12$ \\
\hline 38 & 05579500 & $\begin{array}{l}\text { Lake Fork near Cornland, Ill. } \\
\text { Lat } 39^{\circ} 57^{\prime} 00^{\prime \prime} \text {, long } 89^{\circ} 23^{\prime} 10^{\prime \prime} \text {, sec.1, } \\
\text { T. } 17 \text { N., R.3 W., Logan County. }\end{array}$ & 214 & $\begin{array}{l}D \\
\text { WQ }\end{array}$ & $\begin{array}{l}1948-81 \\
1978-81\end{array}$ \\
\hline 39 & 05579750 & $\begin{array}{l}\text { Kickapoo Creek tributary at Heyworth, } \\
\text { Ill. } \\
\text { Lat } 40^{\circ} 19^{\prime} 05^{\prime \prime}, \text { long } 88^{\circ} 58^{\prime} 55^{\prime \prime}, \text { sec.34, } \\
\text { T.22 N., R.2 E., McLean County. }\end{array}$ & 3.06 & C & $1956-73$ \\
\hline 40 & 05580000 & $\begin{array}{l}\text { Kickapoo Creek at Waynesville, Ill. } \\
\text { Lat } 40^{\circ} 15^{\prime} 20^{\prime \prime} \text {, long } 89^{\circ} 07^{\prime} 40^{\prime \prime} \text {, secs. } 19 \\
\text { \& } 20, \text { T.21 N., R.1 E., De Witt County. }\end{array}$ & 227 & $\begin{array}{l}\text { D } \\
\text { WQ }\end{array}$ & $\begin{array}{l}1948-81 \\
1978-81\end{array}$ \\
\hline 41 & 05580500 & $\begin{array}{l}\text { Kickapoo Creek near Lincoln, Ill. } \\
\text { Lat } 40^{\circ} 11^{\prime} 30^{\prime \prime} \text {, long } 89^{\circ} 21^{\prime} 40^{\prime \prime} \text {, sec.18, } \\
\text { T.20 N., R.2 W., Logan County. }\end{array}$ & 306 & $\begin{array}{l}\text { D } \\
\text { C } \\
\text { WQ }\end{array}$ & $\begin{array}{l}1944-71 \\
1972-81 \\
1978-81\end{array}$ \\
\hline 42 & 05580700 & $\begin{array}{l}\text { Salt Creek tributary at Middletown, Ill. } \\
\text { Lat } 40^{\circ} 06^{\prime} 00^{\prime \prime} \text {, long } 89^{\circ} 34^{\prime} 55^{\prime \prime} \text {, sec. } 18 \text {, } \\
\text { T. } 19 \text { N., R.4 W., Logan County. }\end{array}$ & .90 & $c$ & $1961-76$ \\
\hline 43 & 05580730 & $\begin{array}{l}\text { Sugar Creek at Towanda Avenue at } \\
\text { Normal, Ill. } \\
\text { Lat } 40^{\circ} 30^{\prime} 12^{\prime \prime} \text {, long } 88^{\circ} 57^{\prime} 26^{\prime \prime} \text {, sec. } 26 \text {, } \\
\text { T.24 N., R.2 E., McLean County. }\end{array}$ & 6.34 & WQ & 1977 \\
\hline
\end{tabular}

\subsection{SURFACE-WATER DISCHARGE SITES AND SURFACE-WATER-QUALITY SAMPLING SITES IN THE




\subsection{SURFACE-WATER DISCHARGE SITES AND SURFACE-WATER- QUALITY SAMPLING SITES IN THE STUDY AREA--Continued}

\begin{tabular}{|c|c|c|c|c|c|}
\hline $\begin{array}{l}\text { Map } \\
\text { site } \\
\text { number }\end{array}$ & $\begin{array}{l}\text { USGS } \\
\text { station } \\
\text { number }\end{array}$ & Station name and location & $\begin{array}{l}\text { Drainage } \\
\text { area } \\
\left(\mathrm{mi}^{2}\right)\end{array}$ & $\begin{array}{l}\text { Type } \\
\text { of } \\
\text { data }\end{array}$ & $\begin{array}{l}\text { Years } \\
\text { of } \\
\text { record }\end{array}$ \\
\hline 44 & 05580740 & $\begin{array}{l}\text { Country Club Branch Sugar Creek at } \\
\text { Bloomington, Ill. } \\
\text { Lat } 40^{\circ} 29^{\prime} 35^{\prime \prime}, \text { long } 88^{\circ} 58^{\prime} 52^{\prime \prime}, \text { sec.34, } \\
\text { T.24 N., R.2 E., McLean County. }\end{array}$ & 1.45 & WQ & 1977 \\
\hline 45 & 05580760 & $\begin{array}{l}\text { Sugar Creek below Franklin Avenue at } \\
\text { Normal, Ill. } \\
\text { Lat } 40^{\circ} 29^{\prime} 46^{\prime \prime}, \text { long } 88^{\circ} 59^{\prime} 29^{\prime \prime}, \text { sec. } 33 \text {, } \\
\text { T.24 N., R.2 E., McLean County. }\end{array}$ & 9.71 & WQ & $1975-78$ \\
\hline 46 & 05580770 & $\begin{array}{l}\text { North Branch Sugar Creek at Towanda } \\
\text { Avenue at Normal, Ill. } \\
\text { Lat } 40^{\circ} 31^{\prime} 00^{\prime \prime}, \text { long } 88^{\circ} 57^{\prime} 38^{\prime \prime}, \text { sec. 26, } \\
\text { T.24 N., R.2 E., McLean County. }\end{array}$ & 2.68 & WQ & 1977 \\
\hline 47 & 05580800 & $\begin{array}{l}\text { North Branch Sugar Creek tributary at } \\
\text { R.R. at Normal, Ill. } \\
\text { Lat } 40^{\circ} 30^{\prime} 20^{\prime \prime} \text {, long } 88^{\circ} 59^{\prime} 23^{\prime \prime} \text {, sec. } 28 \text {, } \\
\text { T.24 N., R. } 2 \text { E., McLean County. }\end{array}$ & 0.56 & C & $1971-74$ \\
\hline 48 & 05580805 & $\begin{array}{l}\text { North Branch Sugar Creek tributary at } \\
\text { Normal, Ill. } \\
\text { Lat } 40^{\circ} 30^{\prime} 06^{\prime \prime} \text {, long } 88^{\circ} 59^{\prime} 25^{\prime \prime}, \text { sec.33, } \\
\text { T.24 N., R.2 E., McLean County. }\end{array}$ & .63 & WQ & 1977 \\
\hline 49 & 05580810 & $\begin{array}{l}\text { North Branch Sugar Creek at Normal, Ill. } \\
\text { Lat } 40^{\circ} 29^{\prime} 55^{\prime \prime} \text {, long } 88^{\circ} 59^{\prime} 29^{\prime \prime} \text {, sec. } 33 \text {, } \\
\text { T.24 N., R.2 E., McLean County. }\end{array}$ & 5.52 & WQ & $1975-77$ \\
\hline 50 & 05580880 & $\begin{array}{l}\text { West Branch Sugar Creek at Normal, Ill. } \\
\text { Lat } 40^{\circ} 30^{\prime} 09^{\prime \prime} \text {, long } 89^{\circ} 00^{\prime} 16^{\prime \prime}, \text { sec.32, } \\
\text { T.24 N., R.2 E., McLean County. }\end{array}$ & 4.28 & WQ & 1977 \\
\hline 51 & 05580910 & $\begin{array}{l}\text { Sugar Creek at Market Street at } \\
\text { Bloomington, Ill. } \\
\text { Lat } 40^{\circ} 29^{\prime} 02^{\prime \prime} \text {, long } 89^{\circ} 01^{\prime} 10^{\prime \prime} \text {, sec.5, } \\
\text { T.23 N., R.2 E., McLean County. }\end{array}$ & 21.6 & WQ & 1977 \\
\hline 52 & 05580920 & $\begin{array}{l}\text { Skunk Creek at Bloomington, Ill. } \\
\text { Lat } 40^{\circ} 29^{\prime} 02^{\prime \prime}, \text { long } 89^{\circ} 01^{\prime} 18^{\prime \prime} \text {, sec.5, } \\
\text { T. } 23 \text { N., R.2 E., McLean County. }\end{array}$ & 6.32 & WQ & 1977 \\
\hline 53 & 05580930 & $\begin{array}{l}\text { West slough at Bloomington, Ill. } \\
\text { Lat } 40^{\circ} 28^{\prime} 50^{\prime \prime}, \text { long } 89^{\circ} 01^{\prime} 09^{\prime \prime}, \text { sec.5, } \\
\text { T.23 N., R.2 E., McLean County. }\end{array}$ & 3.22 & WQ & $1975-77$ \\
\hline
\end{tabular}




\begin{tabular}{|c|c|c|c|c|c|}
\hline $\begin{array}{l}\text { Map } \\
\text { site } \\
\text { number }\end{array}$ & $\begin{array}{l}\text { USGS } \\
\text { station } \\
\text { number }\end{array}$ & Station name and location & $\begin{array}{l}\text { Drainage } \\
\text { area } \\
\left(\mathrm{mi}^{2}\right)\end{array}$ & $\begin{array}{l}\text { Type } \\
\text { of } \\
\text { data }\end{array}$ & $\begin{array}{l}\text { Years } \\
\text { of } \\
\text { record }\end{array}$ \\
\hline 54 & 05580945 & $\begin{array}{l}\text { Sugar Creek above sewage Plant at } \\
\text { Bloomington, Ill. } \\
\text { Lat } 40^{\circ} 28^{\prime} 21^{\prime \prime}, \text { long } 89^{\circ} 01^{\prime} 36^{\prime \prime}, \text { sec.7, } \\
\text { T.23 N., R.2 E., McLean County. }\end{array}$ & 32.2 & WQ & $1976-77$ \\
\hline 55 & 05580948 & $\begin{array}{l}\text { Goose Creek above sewage Plant at } \\
\text { Bloomington, Ill. } \\
\text { Lat } 40^{\circ} 28^{\prime} 14^{\prime \prime} \text {, long } 89^{\circ} 01^{\prime} 25^{\prime \prime} \text {, sec.7, } \\
\text { T.23 N., R.2 E., McLean County. }\end{array}$ & 2.19 & WQ & 1977 \\
\hline 56 & 05580950 & $\begin{array}{l}\text { Sugar Creek near Bloomington, Ill. } \\
\text { Lat } 40^{\circ} 28^{\prime} 18^{\prime \prime} \text {, long } 89^{\circ} 01^{\prime} 46^{\prime \prime} \text {, sec. } 7 \text {, } \\
\text { T. } 23 \text { N., R.2 E., McLean County. }\end{array}$ & 34.6 & $\begin{array}{l}\text { D } \\
\text { พQ }\end{array}$ & $\begin{array}{r}1975-81 \\
1975-77\end{array}$ \\
\hline 57 & 05581000 & $\begin{array}{l}\text { Sugar Creek near Armington, Ill. } \\
\text { Lat } 40^{\circ} 15^{\prime} 57^{\prime \prime}, \text { long } 89^{\circ} 20^{\prime} 10^{\prime \prime}, \text { sec. } 21 \text {, } \\
\text { T.21 N., R. } 2 \text { W., Logan County. }\end{array}$ & 314 & D & $1948-49$ \\
\hline 58 & 05581500 & $\begin{array}{l}\text { Sugar Creek near Hartsburg, Ill. } \\
\text { Lat } 40^{\circ} 13^{\prime} 20^{\prime \prime}, \text { long } 89^{\circ} 24^{\prime} 12^{\prime \prime} \text {, sec. } 35 \text {, } \\
\text { T.21 N., R.3 W., Logan County. }\end{array}$ & 333 & $\begin{array}{l}\text { D } \\
\text { C } \\
\text { WQ }\end{array}$ & $\begin{array}{l}1945-71 \\
1972-81 \\
1978-81\end{array}$ \\
\hline 59 & 05582000 & $\begin{array}{l}\text { Salt River near Greenview, Ill. } \\
\text { Lat } 40^{\circ} 08^{\prime} 01^{\prime \prime}, \text { long } 89^{\circ} 44^{\prime} 08^{\prime \prime}, \text { sec. } 2 \text {, } \\
\text { T. } 19 \text { N., R. } 6 \text { W., Mason County. }\end{array}$ & 1,804 & $\begin{array}{l}\text { D } \\
\text { WQ }\end{array}$ & $\begin{array}{l}1942-81 \\
1978-81\end{array}$ \\
\hline 60 & 05582200 & $\begin{array}{l}\text { Cabiness Creek tributary near } \\
\text { Petersburg, Ill. } \\
\text { Lat } 40^{\circ} 02^{\prime} 00^{\prime}, \text { long } 89^{\circ} 46^{\prime} 35^{\prime \prime} \text {, sec.9, } \\
\text { T. } 18 \text { N., R.6 W., Menard County. }\end{array}$ & .94 & C & $1956-76$ \\
\hline 61 & 05582500 & $\begin{array}{l}\text { Crane Creek near Easton, Ill. } \\
\text { Lat } 40^{\circ} 14^{\prime} 46^{\prime \prime}, \text { long } 89^{\circ} 51^{\prime} 40^{\prime \prime}, \text { sec. } 26 \text {, } \\
\text { T.21 N., R.7 W.., Mason County. }\end{array}$ & 26.5 & $\begin{array}{l}\mathrm{D} \\
\mathrm{C}\end{array}$ & $\begin{array}{l}1950-75 \\
1976-81\end{array}$ \\
\hline 62 & 05583000 & $\begin{array}{l}\text { Sangamon River near Cakford, Ill. } \\
\text { Lat } 40^{\circ} 07^{\prime} 25^{\prime \prime}, \text { long } 89^{\circ} 59^{\prime} 05^{\prime \prime} \text {, sec.3, } \\
\text { T. } 19 \text { N., R.8 W., Mason County. }\end{array}$ & 5,093 & $\begin{array}{l}\text { D } \\
\text { D } \\
D \\
D \\
D \\
\text { WQ }\end{array}$ & $\begin{array}{l}1909-12 \\
1914-19 \\
1921-22 \\
1928-33 \\
1939-81 \\
1976-81\end{array}$ \\
\hline 63 & 05583580 & $\begin{array}{l}\text { Panther Creek near Chandlerville, Ill. } \\
\text { Lat } 40^{\circ} 01^{\prime} 45^{\prime \prime} \text {, long } 90^{\circ} 07^{\prime} 38^{\prime \prime}, \text { sec. } 8 \text {, } \\
\text { T. } 18 \text { N., R.9 W., Cass County. }\end{array}$ & 44.9 & WQ & 1981 \\
\hline
\end{tabular}

13.0 SURFACE-WATER DISCHARGE SITES AND SURFACE-WATER-QUALITY SAMPLING SITES IN THE STUDY AREA--Continued 


\subsection{LIST OF REFERENCES}

American Public Health Association, 1976, Standard methods of the examination of water and wastewater: Washington, D.C., 1,193 p.

Andros, S. D., 1915, Coal mining in Illinois: Illinois State Geological Survey Coal Mining Investigation Bulletin 13, $250 \mathrm{p}$.

Curtis, G. W., 1977, Technique for estimating magnitude and frequency of floods in Illinois: U.S. Geological Survey Water-Resources Investigations $77-117,70 \mathrm{p}$.

Dawes, J. H., and Terstriep, M. L., 1966, Potential surface water reservoirs of north-central Illinois: Illinois State Water Survey Report of Investigation $56,144 \mathrm{p}$.

Durfor, C. N., and Becker, Edith, 1964, Public water supplies of the 100 largest cities in the United States, 1962: U.S. Geological Survey Water-Supply Paper 1812, 364 p.

Fehrenbacher, J. B., and Odell, R. T., 1953, Menard County soils: University of Illinois, Agricultural Experiment Station, Soil Report 76, Urbana, Ill., $56 \mathrm{p}$.

Fehrenbacher, J. B., Walker, G. O., and Wascher, H. L., 1967, Soils of Illinois: University of Illinois College of Agriculture, Agricultural Experiment Station, Urbana, Ill., Bulletin 725, $47 \mathrm{p}$.

Frederick, R. H., Myers, V. A., and Auciello, E. P., 1977, Five-to-sixty minute precipitation frequency for the eastern and central United States: National Oceanic and Atmospheric Administration Technical Memorandum NWS HYDRO-35, 36 p.

Gibb, J. P., 1973, Water quality and treatment of domestic ground water supplies: Illinois State Water Survey Circular 118, 17 p.

Hem, J. D., 1970, Study and interpretation of the chemical characteristics of natural water: U.S. Geological Survey Water-Supply Paper 1473, $363 \mathrm{p}$.

Herschfield, D. M., 1961, Rainfall frequency atlas of the United States, U.S. Illinois Conservation Needs Committee, 1970, Illinois soil and water conservation needs inventory: Cooperative Extension Service, College of Agriculture, University of Illinois, Urbana, Ill., 192 p.

Illinois Department of Mines and Minerals, 1982, 1981 Annual coal, oil, and gas report: 403 p.
Illinois Environmental Protection Agency, 1978, Assessment and classification of Illinois lakes, volume I: $173 \mathrm{p}$.

Kirk, J. R., Jarboe, Jacquelyn, Sanderson, E. W., Sasman, R. T., and Sinclair, R. H., 1979, Water withdrawals in Illinois, 1978: Illinois State Water Survey Circular 140, 34 p.

Krauskopf, Konrad B., 1967, Introduction to geochemistry: McGraw-Hill, Inc., New York, $721 \mathrm{p}$.

Larson, T. E., 1963, Mineral content of public ground water supplies in Illinois; Illinois State Water Survey Circular 90, 28 p.

Lewis, J. W., ed., 1971-72, Illinois blue book: 856 p.

Lineback, J. A., 1979, Quaternary deposits of Illinois map: Illinois State Geological Survey, scale 1:500,000.

Nawrot, J. R., Klimstra, W. D., Jenkusky, S. M., and Hickmann, T. J., 1980, Illinois State reclamation plan for abandoned mined land, resource document Cooperative Wildlife Research Laboratory, Southern Illinois University, Carbondale, Ill., 254 p.

Piskin, Kemal, and Bergstrom, R. E., 1975, Glacial drift in Illinois-thickness and character: Illinois State Geological Survey Circular 490, $35 \mathrm{p}$.

Rankama, Kalervo, and Sahama, T. G., 1950, Geochemistry: The University of Chicago Press, 912 p.

Rickert, D. A., Ulman, W. J., and Hampton, E. R., 1979, Synthetic fuels development-Earth science considerations: U.S. Geological Survey Special Report, 45 p.

Rockford Map Publishers, Inc., 1973, Illinois State atlas: Rockford, Ill., 260 p.

Samson, Irma, 1981, Illinois mineral industry in 1978 and a review of preliminary mineral production data for 1979: Illinois State Geological Survey, Illinois Minerals Note 79, $35 \mathrm{p}$.

Selkregg, L. F., and Kempton, J. P., 1958, Groundwater geology in east-central Illinois: Illinois State Geological Survey Circular 248, 36 p.

Sieber, C. R., 1970, A proposed streamflow data program for Illinois: U.S. Geological Survey open-file report, $73 \mathrm{p}$.

Smith, W. H., and Stall, J. B., 1975, updated 1977, Coal and water resources for coal conversion 
in Illinois: Illinois State Water Survey and Illinois State Geological Survey Cooperative Resources Report 4, 79 p.

Thornburn, T. H., 1963, Surface deposits of Illinois-a guide for soil engineers University of Illinois Engineering Experiment Station Circular No. 80, Urbana, Ill., 135 p.

Toler, L. G., 1982, Some chemical characteristics of mine drainage in Illinois: U.S. Geological Survey Water-Supply Paper 2078, 47 p.

U.S. Department of Agriculture, 1974, Soil survey of Logan County, Illinois: Soil Conservation Service in cooperation with Illinois Agricultural Experiment Station, $99 \mathrm{p}$. $1980 \mathrm{a}$, Land resources inventory by river basins of Illinois: Watershed-River Basin Planning Staff, Soil Conservation Service, Champaign, Ill., $53 \mathrm{p}$. 1980b, Survey of Sangamon County, Illinois: Soil Conservation Service in cooperation with Illinois Agricultural Experiment Station, $87 \mathrm{p}$.

U.S. Environmental Protection Agency, 1976
[1978], Quality criteria for water: Washington, D.C., U.S. Government Printing Office, 56 p. 1977, National secondary drinking water regulations: Federal Register, v. 42 , no. 62, Thursday, March 31, 1977, Part I, p. 17143-17147.

Van Den Berg, Jacob, and Elyn, J. R., 1981, Petroleum industry in Illinois, 1979: Illinois State Geological Survey, Illinois petroleum 120, $132 \mathrm{p}$.

Willman, H. B., and Frye, J. C., 1970, Pleistocene stratigraphy of Illinois: Illinois State Geological Survey Bulletin 94, $204 \mathrm{p}$.

Willman, H. B., and others, 1967, Geologic map of Illinois: Illinois State Geological Survey, scale $1: 500,000$.

1975, Illinois stratigraphy: Illinois State Geological Survey Bulletin 95, 261 p.

Wischmeier, W. H., and Smith, D. D., 1978, Predicting rainfall erosion losses-a guide to conservation planning: U.S. Department of Agriculture, Agriculture Handbook No. 537, $58 \mathrm{p}$. 